Universidade de São Paulo

Instituto de Ciências Biomédicas

IVO MARGUTI

\title{
EFEITO DAS CÉLULAS DENDRÍTICAS NA GERAÇÃO DE CÉLULAS T CD $4^{+} \mathrm{CD}^{2} 5^{+}{ }^{\circ} \mathrm{oxp} 3^{+}$
}

\author{
Dissertação de Mestrado apresentada ao \\ Instituto de Ciências Biomédicas da \\ Universidade de São Paulo para a obtenção \\ do Título de Mestre em Ciências (Imunologia)
}

São Paulo 
IVO MARGUTI

\section{EFEITO DAS CÉLULAS DENDRÍTICAS NA GERAÇÃO DE CÉLULAS T CD4 ${ }^{+} \mathrm{CD}^{2} 5^{+}{ }^{+}$oxp $3^{+}$}

Dissertação de Mestrado apresentada ao Instituto de Ciências Biomédicas da Universidade de São Paulo para a obtenção do Título de Mestre em Ciências (Imunologia)

Área de concentração:

Imunologia

Orientador:

Prof. Dr. Luiz Vicente Rizzo

São Paulo 
DADOS DE CATALOGAÇÃO NA PUBLICAÇÃO (CIP)

Serviço de Biblioteca e Informação Biomédica do Instituto de Ciências Biomédicas da Universidade de São Paulo

(C) reprodução total

Marguti, Ivo.

Efeito das células dendríticas na geração de células $T$ CD4 CD25 ${ }^{+}$Foxp3 $^{+}$/ Ivo Marguti. -- São Paulo, 2007.

Orientador: Luiz Vicente Rizzo.

Dissertação (Mestrado) - Universidade de São Paulo. Instituto de Ciências Biomédicas. Departamento de Imunologia. Área de concentração: Imunologia. Linha de pesquisa: Imunoregulação.

Versão do título para o inglês: Effect of dendritic cells on the generation of $\mathrm{CD}^{+} \mathrm{CD} 25^{+}$Foxp3 ${ }^{-} \mathrm{T}$ cells .

Descritores: 1. Tolerância imunológica 2 . Céluas dendríticas 3. Células $T$ reguladoras 4. Apresentação de antígenos 5. Foxp3 I.

Rizzo, Luiz Vicente II. Universidade de São Paulo. Instituto de Ciências Biomédicas. Programa Pós-Graduação em Imunologia. III. Título. 


\section{Certificado}

Certificamos que o protocolo registrado sob $n^{\circ} 105$ nas fls. 21 do livro 2 para uso de animais em experimentação, sob a responsabilidade do(a) Prof.(a) Dr.(a) Luiz Vicente Rizzo, Coordenador(a) da Linha de Pesquisa "Avaliação do efeito das células dendriticas imaturas na geração de células $T$ reguladoras in vitro" do qual participou(aram) o(s) aluno(s): Ivo Marguti e a pesquisadora Lucina de Deus Vieira de Moraes está de acordo com os Princípios Éticos de Experimentação Animal adotado pelo Colégio Brasileiro de Experimentação Animal (COBEA) e foi aprovado pela COMISSĀO DE ÉTICA EM EXPERIMENTAÇÃO ANIMAL (CEEA) em 24.10.2005.

São Paulo, 24 de outubro de 2005.

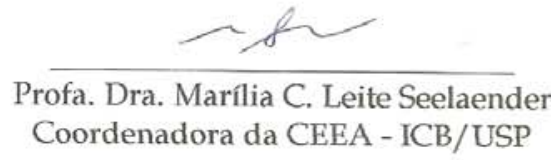

Profa. Dra. Marília C. Leite Seelaender ordena

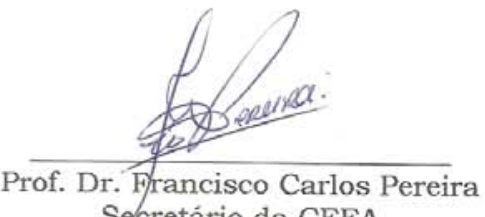

Secretário da CEEA 


\section{DEDICATÓRIA}

Ao meu pai Richard, à minha mãe Clélia, aos meus irmãos Bárbara e Vitor.

As mais brilhantes estrelas na mais escura das noites. 


\section{Agradecimentos}

Ao Professor Luiz Vicente Rizzo, pela oportunidade de fazer parte do Laboratório de Imunologia Clínica durante três anos de novas descobertas e aprendizado constante. Sempre terei boas lembranças deste período.

À Dra. Luciana Vieira de Moraes, presença constante e indispensável do início ao fim deste trabalho.

Ao meu pai Richard, minha mãe Clélia, minha irmã Bárbara e meu irmão Vitor. Sem vocês nada teria valido a pena.

À Elô pela paciência, compreensão e companheirismo indispensáveis durante a realização deste trabalho. Você tornou o caminho mais suave.

Aos grandes amigos Jean e Ricardo pelos momentos de descontração e pelas discussões intermináveis.

A todas as pessoas que passaram pelo Laboratório de Imunologia Clínica durante esses anos. A ajuda e amizade de cada um de vocês foram importantes para a conclusão deste trabalho.

A todas as pessoas do Laboratório de Biologia Celular e Molecular, pela amizade cultivada durante os anos.

Aos amigos Zé, Fran, Sarita, Bia, André, Gabriel, Fausto, Alberto e Rafael. Vocês são parte deste trabalho.

Aos colegas de Departamento pelos bons momentos compartilhados durante os anos de estudo.

À minha banca de qualificação, Prof. Niels Olsen Câmara, Dra. Karina Bastos e Dra. Verônica Coelho. As críticas e sugestões feitas durante e após o exame de qualificação ajudaram a tornar este trabalho mais sólido.

Aos funcionários do Biotério de Criação e Experimentação do ICB-USP e aos funcionários do Departamento de Imunologia, sempre solícitos e competentes.

A todos que direta ou indiretamente ajudaram na realização deste trabalho, meu sincero obrigado! 
O presente trabalho foi realizado com o apoio da Fundação de Amparo à Pesquisa do Estado de São Paulo (FAPESP) e do Conselho Nacional de Desenvolvimento Científico e Tecnológico (CNPq). 
This is about a certain type of life that is concerned with asking questions and seeking answers that hold up on further testing and scrutiny. 


\section{Resumo}

Marguti, I. Efeito das células dendríticas na geração de células T $\mathrm{CD}^{+} \mathrm{CD} 25^{+} \mathrm{Foxp} 3^{+}$. Dissertação (Mestrado em Imunologia) - Instituto de Ciências Biomédicas, Universidade de São Paulo, São Paulo, 2007.

As células dendríticas (DCs) são as principais células apresentadoras de antígeno do sistema imune. No entanto, trabalhos recentes têm demonstrado seu envolvimento na manutenção da tolerância imunológica, possivelmente por suas interações com a população de células $\mathrm{T} \mathrm{CD}^{+} \mathrm{CD} 25^{+} \mathrm{Foxp}^{+}$. Estas células possuem reconhecida capacidade de suprimir respostas imunes. Neste estudo avaliamos as alterações ocorridas na população de células $\mathrm{CD} 4^{+} \mathrm{CD} 25^{+} \mathrm{Foxp}^{+}$após co-cultura de células de linfonodo com DCs derivadas de células da medula óssea de camundongos BALB/c na presença ou ausência de células alogênicas em apoptose. A análise das DCs obtidas demonstrou que elas possuem características fenotípicas e funcionais compatíveis com as descritas na literatura. As citocinas produzidas por elas também foram analisadas e nossos resultados demonstram que a produção de IL-10, IL-12 e TNF- $\alpha$ ocorre apenas quando as DCs são ativadas por LPS. Por sua vez, tanto as DCs imaturas quanto as ativadas por LPS produzem TGF- $\beta$. Após o co-cultivo das DCs com células de linfonodo observamos aumento da população de linfócitos $\mathrm{T} \mathrm{CD} 4^{+} \mathrm{CD} 25^{+} \mathrm{Foxp}^{+}$de maneira independente do estado de ativação das DCs ou da presença de aloantígenos. Apesar do aumento em todas as condições experimentais analisadas, notamos que este foi maior quando DCs imaturas foram incubadas com antígenos alogênicos. Em todas as condições experimentais em que foi verificado aumento na população de células $C D 4^{+} \mathrm{CD} 25^{+} \mathrm{Foxp} 3^{+}$foi também verificada a presença de TGF- $\beta$. Estes resultados podem indicar uma correlação entre a presença desta citocina e o aumento na população $\mathrm{CD} 4^{+} \mathrm{CD} 25^{+}{ }$oxp $^{+}$. Para avaliar a contribuição das células $\mathrm{T} \mathrm{CD}^{+} \mathrm{CD} 25^{+}$no aumento da população de células $\mathrm{CD} 4^{+} \mathrm{CD} 25^{+} \mathrm{Foxp}^{+}$, a primeira foi depletada antes do início da co-cultura entre células de linfonodo e DCs. Neste caso, observamos um aumento na população de células $\mathrm{CD} 4^{+} \mathrm{CD} 25^{+}{ }^{+}$oxp3- quando as DCs são previamente incubadas com aloantígeno. Nossos dados demonstram também que nesta situação o aumento na população de células $\mathrm{CD}^{+}{ }^{+} \mathrm{CD} 25^{+}{ }^{+} \mathrm{oxp}^{+}$é menor. Tomados em conjunto, estes dados demonstram que após a co-cultura de células de linfonodo com DCs há um aumento da população de células $\mathrm{T} C D 4^{+} \mathrm{CD} 25^{+} \mathrm{Foxp} 3^{+}$. Nossos dados também sugerem que este aumento é decorrente da proliferação desta população celular e não da geração destas células a partir de células T CD4 ${ }^{+} \mathrm{CD} 25^{+}$Foxp3:

Palavras-chave: Tolerância Imunológica. Células dendríticas. Células $\mathrm{T}$ reguladoras. Apresentação de antígenos. Foxp3. 


\begin{abstract}
Marguti, I. Effect of dendritic cells on the generation of $\mathrm{CD} 4^{+} \mathrm{CD} 25^{+} \mathrm{Foxp} 3^{+} \mathrm{T}$ cells. Thesis (Immunology) - Instituto de Ciências Biomédicas, Universidade de São Paulo, São Paulo, 2007.
\end{abstract}

Dendritic cells (DCs) are the most important antigen-presenting cells of the immune system. However, recent works have also implicated DCs in the maintenance of immunologic tolerance, possibly through its interactions with $\mathrm{CD} 4^{+} \mathrm{CD} 25^{+} \mathrm{Foxp} 3^{+} \mathrm{T}$ lymphocytes. These cells are known for their regulatory capacity. In this study we evaluated the changes in the $\mathrm{CD}^{+} \mathrm{CD} 25^{+} \mathrm{Foxp}^{+} \mathrm{T}$ cell population from BALB/c mice after co-culture of lymph-node cells with syngeneic DCs derived from bone marrow cells in the presence or absence of allogeneic apoptotic cells. Characterization of the DC population regarding the expression of surface markers and the capacity of $\mathrm{T}$ cell stimulation show that they have similar properties as the ones described in the literature. Mature, but not immature DCs produced considerable amounts of IL-10, IL-12 and TNF- $\alpha$. TGF- $\beta$ was produced by both, immature and activated DCs. Our results show an increase in the $\mathrm{CD} 4^{+} \mathrm{CD} 25^{+} \mathrm{Foxp} 3^{+} \mathrm{T}$ cell population after coculture of lymph-node cells with DCs. This increase occurs regardless of the activation state of DCs and the presence of alloantigens; however it was greater when immature DCs were previously pulsed with aloantigens. In all experimental settings where the $\mathrm{CD} 4^{+} \mathrm{CD} 25^{+} \mathrm{Foxp} 3^{+}$ population increased we also noticed the presence of TGF- $\beta$. These data suggest a correlation between the presence of this cytokine and the increase in the $\mathrm{CD} 4^{+} \mathrm{CD} 25^{+} \mathrm{Foxp} 3^{+}$ population. We also cultured lymph node cells from naïve BALB/c mice depleted of CD $4^{+} \mathrm{CD} 25^{+} \mathrm{T}$ cells with DCs. In this setting we observed an increase in the $\mathrm{CD}^{+}{ }^{+} \mathrm{CD} 25^{+}{ }^{+}$oxp3 $^{-} \mathrm{T}$ cell population. Moreover, we observed a smaller increase in the CD $4^{+}$CD $25^{+}$Foxp $^{+} \mathrm{T}$ cell population. Taken together, our data show that the CD4 ${ }^{+} \mathrm{CD} 25^{+} \mathrm{Foxp}^{+} \mathrm{T}$ cell population expands after co-culture of lymph-node cells with DCs suggesting that expansion is due to the proliferation of the this cells population rather than conversion of $\mathrm{CD} 4^{+} \mathrm{CD} 25^{+}$Foxp3 $3^{-}$into $\mathrm{CD} 4^{+} \mathrm{CD} 25^{+} \mathrm{Foxp}^{+}$cells.

Key words: Immunologic Tolerance. Dendritic cells. Regulatory $\mathrm{T}$ cells. Antigen presentation. Foxp3. 


\section{Sumário}

1. Introdução 14

2. Objetivos 38

2.1. Objetivos gerais 38

2.2. Objetivos específicos 38

3. Materiais e Métodos 40

3.1. Animais 40

3.2. Geração de células dendríticas $\quad 40$

3.3. Citometria de fluxo 41

3.4. Cultura leucocitária mista utilizando células dendríticas como células estimuladoras 42

3.5. Obtenção de células apoptóticas 43

3.6. Análise de apoptose via conteúdo de DNA (HFS) 44

3.7. Ensaios de fagocitose 44

3.8. Análise da produção de citocinas pelas células dendríticas 45

3.9. Co-cultura de células dendríticas com células de linfonodo 47

3.10. Isolamento de células $\mathrm{CD} 4^{+} \mathrm{CD} 25^{+} \quad 48$

3.11. Análise estatística 49

4. Resultados

4.1. Caracterização fenotípica das células dendríticas 51

4.2. Estado de ativação das células dendríticas 53

4.3. Caracterização funcional das células dendríticas 55

4.4. Avaliação da apoptose em timócitos 57

4.5. Avaliação do estado de ativação das células dendríticas co-cultivadas com timócitos alogênicos em apoptose 
4.6. Verificação da fagocitose de células alogênicas em apoptose por células dendríticas

4.7. Análise da produção de citocinas pelas DCs em diferentes condições experimentais

4.8. Avaliação da expressão de Foxp3 nas células T CD4 ${ }^{+}$

4.9. Efeito da depleção das células $C D 4^{+} C D 25^{+}$presentes nos linfonodos de animais naïve nas alterações verificadas na população de células T reguladoras

5. Discussão

6. Conclusões

7. Referências 


\section{Introdução}




\section{Introdução}

Em meados da década de 70 pesquisadores do laboratório de Zanvil Cohn descreveram uma nova população de células presentes no baço e linfonodos de camundongos. Tais células possuíam características morfológicas e funcionais que as diferenciavam de outras células presentes nesses órgãos. Os pesquisadores caracterizaram-nas baseando-se em aspectos como a morfologia, localização in vivo, quantidade de células em diferentes órgãos linfóides periféricos e suas propriedades funcionais, e denominaram-nas células dendríticas (DCs, do inglês dendritic cells) (Steinman et al, 1973; Steinman et al, 1974a; Steinman et al, 1974b, Steinman et al, 1975). Desde então as DCs passaram a receber cada vez mais a atenção de pesquisadores e a ocupar um lugar de destaque na pesquisa em imunologia. Este interesse pode ser demonstrado claramente quando observamos a evolução no número de trabalhos publicados sobre as células dendríticas desde sua descrição inicial (figura 1).

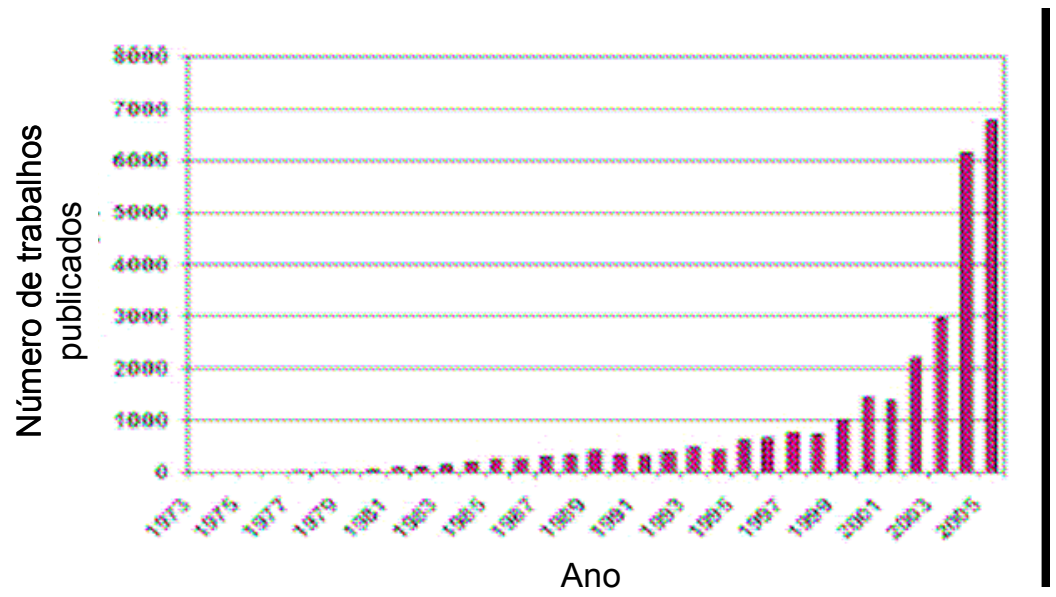

Figura 1. Número aproximado de publicações relacionadass com células dendríticas publicados ano a ano a partir de sua descrição original. $\mathrm{O}$ gráfico é baseado em busca realizada no PubMed (www.pubmed.com) utilizando-se os termos "dendritic cells" e "immunology". (Adaptado de Trinchieri, 2007) 
As células dendríticas podem ser subdivididas em diferentes subpopulações, que possuem como característica fenotípica comum a expressão da molécula CD11c. As principais diferenças fenotípicas entre as subpopulações de células dendríticas são a expressão diferencial dos marcadores CD11b, CD8 e B220. As DCs que expressam B220 apresentam quantidades intermediárias da molécula CD11c em sua superfície, e são denominadas "células dendríticas plasmacitóides" (pDCs). As DCs caracterizadas pela alta expressão de CD11c são denominadas "células dendríticas convencionais" (cDC) e subdivididas, em células CD8 positivas e CD8 negativas, sendo que as células CD8 negativas expressam a molécula CD11b. Há ainda populações de DCs caracterizadas pela expressão de CD4, concomitante ou não, com a expressão de CD8. No entanto, essa subpopulação é menos estudada, sendo os subtipos de cDCs geralmente divididos somente em CD8 positivas ou negativas. As diferentes subpopulações de células dendríticas apresentam, além das diferenças fenotípicas, algumas diferenças funcionais e em seu desenvolvimento (Shortman \& Liu, 2002; Shortman \& Naik, 2007).

A ontogenia das células dendríticas plasmacitóides parece ser distinta da ontogenia das células dendríticas convencionais. Evidências demonstram uma divergência em algum ponto da ontogenia destas células que gera precursores específicos de pDCs, incapazes de gerar cDCs. Alguns fatores de transcrição têm sido implicados no desenvolvimento das pDCs. Estudos em camundongos manipulados geneticamente para expressar quantidades diminuídas do fator de transcrição Ikaros em suas células hematopoieticas demonstraram que, nestes animais as pDCs não completam todo seu programa de desenvolvimento apesar de precursores inicias serem encontrados na medula óssea. Estes camundongos, portanto, apresentam números normais de cDCs e números reduzidos de pDCs (Allman et al, 2006). Por outro lado, camundongos deficientes no regulador de transcrição IRF-1 apresentam um aumento da população de pDCs e uma diminuição na população de cDCs (Gabriele et al, 2006). Estes estudos indicam que a geração de pDCs ocorre por vias de 
desenvolvimento e possui necessidades, pelo menos em parte, diferentes das requeridas para a geração de cDCs.

Apesar das pDCs possuírem a capacidade de apresentar antígenos e estimular respostas imunes adaptativas, como as observadas nas cDCs, estas células possuem propriedades funcionais que as diferem das últimas. Estas propriedades estão associadas à expressão diferencial de receptores do tipo Toll (TLR do inglês, Toll-Like Receptors) entre os diferentes subtipos de DCs. As pDCs expressam quantidades significativamente maiores de TLR-7 e TLR-9 do que as cDCs, o que as torna especializadas no reconhecimento de ácidos nucléicos derivados de patógenos, especialmente ácidos nucléicos virais. A ativação dos TLR-7 e -9, pela ligação com seus agonistas, nas pDCs induz a produção de grandes quantidades de interferons do tipo I, citocinas envolvidas na proteção contra infecções virais. Devido a estas características as pDCs são reconhecidas como células envolvidas na proteção contra este tipo de infecção (Ito et al, 2005; Cao \& Liu, 2007).

Em relação ao desenvolvimento das células dendríticas convencionais existe uma maior quantidade de dados na literatura, possibilitando um entendimento mais amplo de sua ontogenia. No início da década de 90 Ardavin e cols. (1993) demonstraram pela primeira vez que as células dendríticas presentes no timo podiam ser geradas a partir de precursores linfóides. Neste trabalho, foi demonstrado também que aproximadamente $60 \%$ das DCs derivadas de precursores linfóides expressavam a molécula CD8. Convencionou-se, então, chamar as células dendríticas caracterizadas pela expressão de CD8 de "células dendríticas linfóides", enquanto as caracterizadas pela expressão de CD11b foram denominadas "células dendríticas mielóides".

No entanto, uma série de experimentos posteriores acabou por enfraquecer a tese de que as células dendríticas derivadas de progenitores linfóides eram caracterizadas pela expressão de CD8. Experimentos realizados por Bjorck e cols. (1998) demonstraram vias comuns de desenvolvimento entre linfócitos B e células dendríticas, reforçando a idéia de 
que as células dendríticas podem ser obtidas a partir de precursores linfóides. Todavia, estas células não expressavam a molécula CD8 em sua superfície. Traver e cols. (2000) demonstraram, por sua vez, que uma população purificada de precursores mielóides ao ser transferida para camundongos congênicos irradiados dava origem a DCs que expressavam CD8 e a DCs que não expressavam esta molécula. Mais, os autores demonstraram que todas as células dendríticas derivadas de precursores mielóides encontradas no timo expressavam CD8, enquanto no baço encontravam-se células dendríticas CD8 positivas e CD8 negativas. Subseqüentemente, os trabalhos de Manz e cols. (2001) e Wu e cols. (2001) confirmaram estes resultados indicando que a expressão de CD8 não pode ser utilizada para determinar qual precursor, linfóide ou mielóide, deu origem a qual subtipo de DC. Atualmente, a tese mais aceita é de que ambos precursores, linfóide e mielóide, podem dar origem a todos os subtipos de células dendríticas encontradas em camundongos naïve.

A demonstração de que tanto precursores linfóides como mielóides podem dar origem aos diferentes subtipos de DCs incentivou pesquisadores a buscar precursores tardios de células dendríticas já comprometidos com a geração das diferentes sub-populações. Naik et al (2006) demonstraram que no baço de camundongos naïve pode-se encontrar populações celulares comprometidas com a geração das diferentes subpopulações de células dendríticas. Uma análise fenotípica detalhada demonstrou que estas células eram caracterizadas fenotipicamente como $\mathrm{CD} 11 \mathrm{c}^{\text {int }} \mathrm{CD} 4^{-} \mathrm{CD} 8^{-} \mathrm{MHCll}^{-}$. Esta população foi ainda subdividida quanto à expressão da molécula CD24. Ensaios posteriores demonstraram que a população CD24 ${ }^{\text {high }}$ gerava especificamente DCs que expressavam CD8, enquanto a população CD24 ${ }^{\text {low }}$ gerava exclusivamente células que não expressavam CD8.

As semelhanças no desenvolvimento de DCs e macrófagos também têm sido estudadas. Fogg e cols. (2006) demonstraram que o mesmo progenitor presente na medula óssea de camundongos pode dar origem a células dendríticas e a macrófagos. Os autores identificaram este progenitor fenotipicamente como $\mathrm{CX}_{3} \mathrm{CR} 1^{+} \mathrm{CD} 117^{+} \mathrm{Lin}$. Estas células ao 
serem tratadas, in vitro, com fator estimulador de colônias de macrófagos (M-CSF) deram origem a populações de macrófagos, enquanto o tratamento com fator estimulador de colônia de granulócitos e macrófagos (GM-CSF) deu origem a células dendríticas. Para determinar se este fenômeno se repetia in vivo os autores inocularam células $\mathrm{CX}_{3} \mathrm{CR} 1^{+} \mathrm{CD} 117^{+} \mathrm{Lin}^{-}$purificadas em camundongos. Quando estas células foram recuperadas, observou-se que elas haviam gerado DCs e macrófagos, mas não outras populações celulares. Estes dados confirmaram os dados obtidos in vitro pelos autores e demonstraram que o mesmo progenitor presente na medula óssea, quando submetido a diferentes estímulos, pode originar DCs e macrófagos.

Os trabalhos citados acima tratam da geração de células dendríticas encontradas em órgãos linfóides, especialmente no baço, de animais livres de doença ou inflamação. Por outro lado, estudos com enfoque em DCs geradas em condições inflamatórias têm demonstrado que monócitos podem dar origem a DCs, reforçando a hipótese de uma relação próxima entre estas e os macrófagos. Utilizando um modelo de inflamação de pele Ginhoux e cols. (2006) demonstraram que células de Langerhans, um subtipo específico de células dendríticas presentes na epiderme, podem ser geradas a partir de monócitos. Naik et al (2006) utilizando um protocolo de inflamação dependente da produção de GM-CSF, que consiste na imunização de animais com albumina bovina metilada emulsificada em Adjuvante Completo de Freund e posterior desafio destes animais com o mesmo antígeno, demonstraram que monócitos podem dar origem a DCs no baço. Os autores sugerem que as células dendríticas obtidas a partir de monócitos em condições inflamatórias são semelhantes às DCs obtidas in vitro pelo cultivo de células de medula óssea na presença de GM-CSF.

Além de poderem ser distinguidas quanto às subpopulações, as células dendríticas podem ser diferenciadas quanto ao seu estado de ativação. Na ausência de sinais inflamatórios ou infecção, as DCs possuem um fenótipo caracterizado pela baixa expressão de moléculas do complexo de histocompatibilidade principal de classe II (MHC II) e das moléculas co- 
estimuladoras como CD80, CD86 e CD40. Quando sinais inflamatórios estão presentes ou as DCs são expostas a componentes derivados de patógenos, como o lipopolissacarídeo bacteriano (LPS) ou RNA dupla fita, seu fenótipo sofre uma alteração significativa, com um aumento na expressão de MHC II e moléculas co-estimuladoras (Guermonprez et al, 2002).

As DCs presentes nos tecidos possuem uma alta capacidade de capturar antígenos e apresentam baixa expressão de moléculas co-estimuladoras, sendo denominadas células dendríticas imaturas. Quando neste estado de ativação, as DCs são pobres estimuladoras de respostas de células T. Quando componentes derivados de patógenos ou sinais inflamatórios estão presentes, as células dendríticas sofrem um processo denominado maturação, compreendendo mudanças funcionais e fenotípicas. As DCs são então ditas células dendríticas maduras e tornam-se capazes de estimular respostas de células $T$ (Guermonprez et al, 2002). Quando maduras as DCs diminuem sua capacidade de capturar antígenos e migram para os linfonodos. Durante o processo de maturação a expressão do receptor de quimiocina CCR6 diminui, ao passo que a expressão do receptor CCR7 aumenta. A quimiocina MIP-3ß, ligando-se ao CCR7, guia a migração das DCs maduras para os linfonodos e sua fixação nas áreas de células T (Dieu et al, 1998). Dessa forma, o processo de maturação das células dendríticas integra-se ao processo de migração das mesmas em direção às áreas $\mathrm{T}$ dos linfonodos, fazendo com que a probabilidade do encontro com um linfócito T antígeno-específico aumente.

A primeira descrição das propriedades funcionais das células dendríticas foi feita por Steinman e Witmer (1978). Neste trabalho, os autores demonstraram que a capacidade de células esplênicas induzirem proliferação de linfócitos alogênicos em uma cultura leucocitária mista era dada principalmente pelas DCs contidas neste órgão. Além disso, foi demonstrado que células dendríticas purificadas eram capazes de, sozinhas, estimular a proliferação de células $T$ alogênicas de maneira muito mais potente do que outras populações celulares presentes no baço. A partir de então, um grande número de trabalhos 
visando caracterizar os mecanismos pelos quais as células dendríticas eram capazes de estimular o desenvolvimento de respostas imunes adaptativas foi publicado.

Inaba e cols. (1983) demonstraram que a capacidade de linfócitos B produzirem anticorpos anti-hemácias de carneiro, in vitro, era dependente da presença de células dendríticas na cultura. Linfócitos B cultivados em condições em que apenas linfócitos $T$ e hemácias de carneiro estavam presentes não eram capazes de produzir anticorpos contra as hemácias. No entanto, a adição de números crescentes de células dendríticas às culturas restabeleceu a capacidade de produção de anticorpos pelos linfócitos B. O mesmo grupo demonstrou posteriormente (Inaba et al, 1984) que as células dendríticas formavam aglomerados com linfócitos T naïve e que a formação destes aglomerados estava ligada à capacidade única das DCs em estimular estes linfócitos.

Outros trabalhos envolvendo a capacidade das DCs em gerar respostas imunes efetivas foram realizados utilizando-se linfócitos T CD8 como células respondedoras. Inaba et al (1987), utilizando como modelo experimental culturas leucocitárias mistas realizadas com subpopulações específicas de linfócitos $T$, demonstraram que DCs são capazes de formar aglomerados com linfócitos T CD8 de maneira semelhante aos formados entre DCs e linfócitos T CD4. Os autores demonstraram também que os linfócitos T CD8 podiam ser ativados pelas DCs na ausência de ajuda provida pelos linfócitos T CD4. Utilizando-se um modelo experimental de infecção com o vírus Influenza, Macatonia e cols. (1989) demonstraram que DCs infectadas com o vírus, in vitro ou in vivo, eram capazes de estimular a geração de uma resposta citotóxica específica.

O trabalho de Macatonia e cols. (1989) demonstra que DCs isoladas de órgãos linfóides de animais infectados com o vírus Influenza são capazes de estimular linfócitos $\mathrm{T}$, demonstrando assim que a captura de antígenos pelas DCs in vivo é importante para o desenvolvimento de uma resposta imune efetiva. Subseqüentemente, Crowley et al (1990) demonstraram que após a injeção de antígenos protéicos em camundongos, por via intravenosa ou intraperitoneal, as DCs esplênicas eram as principais células que 
carregavam fragmentos imunogênicos em sua superfície. Além disso, foi demonstrado que estas células, quando isoladas, eram capazes de gerar uma resposta de linfócitos T CD4 in vitro. Utilizando o procedimento inverso, isto é, incubando-se DCs isoladas do baço de camundongos naïve in vitro com antígenos protéicos e injetando-se estas células em camundongos, o mesmo grupo de pesquisadores demonstrou que as DCs foram capazes de induzir a geração de uma resposta imune específica e restrita pelo MHC in vivo (Inaba et al, 1990).

A capacidade das DCs produzirem citocinas é um fator importante para sua habilidade ímpar de induzir a geração de imunidade adaptativa. As citocinas produzidas pelas DCs tornam-se parte do microambiente em que a resposta imune se desenvolve e podem alterála significativamente, sendo inclusive classificadas por alguns autores como o "terceiro sinal" capaz de guiar o desenvolvimento das propriedades efetoras dos linfócitos T naïve (Reis e Sousa, 2006). Spörri e Reis e Sousa (2005) demonstraram, de maneira muito elegante, que células dendríticas caracterizadas fenotipicamente como maduras mas que não produzem IL-12, são capazes de induzir a proliferação de linfócitos $T$ naïve. Porém, os linfócitos estimulados são incapazes de realizar suas funções efetoras. Por outro lado, células dendríticas capazes de produzir altas quantidades de IL-10 podem induzir a geração de linfócitos T produtores de IL-10 e com propriedades supressoras (Wakkach et al, 2003; Svensson et al, 2004).

A apresentação cruzada de antígenos é um processo realizado exclusivamente por DCs. Neste processo, antígenos exógenos são capturados pelas DCs e apresentados via MHC de classe I para linfócitos T CD8. A capacidade de realizar este processo parece ser a principal diferença funcional entre os dois principais subtipos de células dendríticas convencionais. Estudos realizados por den Hann e cols. (2000) demonstraram , in vivo, que apenas as DCs $\mathrm{CD8}^{+}$são capazes de apresentar antígenos via MHC de classe I após a aquisição dos mesmos a partir do meio extracelular. Esta capacidade é dependente da ação da proteína TAP (do inglês, Transporter Associated with Antigen Presentation), responsável pelo 
transporte de peptídios presentes no citosol para o interior do retículo endoplasmático onde os mesmos se ligarão às moléculas de $\mathrm{MHC}$ de classe I. De maneira interessante, este fato não se deve a diferenças na capacidade de captura de antígeno pelos diferentes subtipos de células dendríticas (den Haan et al, 2000; Schnorrer et al, 2006) nem à forma do antígeno (solúvel ou particulado) (Pooley et al, 2001; Schnorrer et al, 2006).

Recentemente, foi demonstrado que as diferenças observadas entre as células dendríticas $\mathrm{CD8}^{+}$e CD8${ }^{-}$na realização da apresentação cruzada se correlaciona com diferenças na expressão de proteínas envolvidas nas diferentes vias de apresentação de antígeno. Enquanto as DCs CD8 expressam grandes quantidades de moléculas envolvidas na apresentação de antígeno por via do $\mathrm{MHC}$ de classe II, as células dendríticas CD8 ${ }^{+}$ expressam grandes quantidades de moléculas envolvidas na apresentação de antígeno por via do MHC de classe I (Dudziak et al, 2007). Estes dados oferecem uma explicação molecular para a diferença funcional observada entres estes subtipos de DCs.

Apesar de intrinsecamente relacionadas com a geração de respostas imunes adaptativas, as células dendríticas possuem também um papel essencial na indução e manutenção de tolerância. A presença de células dendríticas com capacidade de apresentação de antígeno no timo, observada em 1986 por Kyewski et al, sugeria o envolvimento destas células nos processos de seleção de linfócitos T. Posteriormente, demonstrou-se que a expressão de antígenos especificamente por DCs no timo, era capaz de induzir a seleção negativa de timócitos em desenvolvimento (Brocker et al, 1997). Recentemente, foi demonstrado, de maneira surpreendente, que DCs presentes na periferia podem migrar para o timo e induzir a deleção de clones de linfócitos T em desenvolvimento reativos ao antígeno apresentado por estas DCs (Bonasio et al, 2006).

O papel das células dendríticas na indução de células T com capacidade supressora e seu papel na manutenção da tolerância periférica têm sido demonstrado em diferentes modelos experimentais, tanto in vitro quanto in vivo. Células dendríticas tratadas com IL-10 perdem a capacidade de maturação e são capazes de induzir anergia em linfócitos T CD4 
aloespecíficos (Steinbrink et al, 1997). Steinbrink et al (1999) demonstraram também que DCs tratadas com IL-10 são capazes de induzir anergia em clones de linfócitos T CD8 específicos para antígenos de melanoma. Jonuleit e cols. (2000) demonstraram que a estimulação repetida de linfócitos T com DCs alogênicas imaturas pode induzir a geração de linfócitos T com propriedades reguladoras, secretores de IL-10 e com baixa capacidade proliferativa. Cultivando células dendríticas a partir de precursores da medula óssea na presença de IL-10 Wakkach e cols. (2003) obtiveram um subtipo de célula dendrítica caracterizada pela alta expressão de CD45RB. Estas células foram também identificadas in vivo. Funcionalmente, essas DCs foram caracterizadas pela secreção de altos níveis de IL10 e pela capacidade de induzir células T reguladoras do tipo $1(\operatorname{Tr} 1)$, capazes de regular respostas imunes de forma antígeno específica.

As células dendríticas possuem também a capacidade de induzir a morte de clones reativos na periferia. Células dendríticas $\mathrm{CD}^{+}$imaturas que tenham capturado células mortas que haviam incorporado o antígeno ovalbumina, são capazes de induzir a deleção de clones de linfócitos $\mathrm{T} \mathrm{CD8}^{+}$reativos à ovalbumina (Liu et al, 2002). Resultados semelhantes foram obtidos quando se utilizou um peptídio acoplado a um anticorpo monoclonal dirigido contra a proteína de membrana DEC-205, expressa por DCs CD8 ${ }^{+}$. Neste modelo experimental, observou-se a deleção tanto de clones de linfócitos T CD4 quanto de clones de linfócitos T CD8 (Hawiger et al, 2001; Bonifaz et al, 2002). De maneira interessante, em todos os trabalhos o tratamento com anticorpo agonista anti-CD40, capaz de ativar as DCs, impedia a deleção dos clones auto-reativos e, ao contrário, induzia a ativação dos mesmos. Estes resultados implicam o estado de maturação das DCs como fator importante na regulação da tolerância periférica.

Os estudos citados acima demonstram que as DCs podem estar envolvidas na regulação da resposta imune alterando o comportamento das células T, seja deletando-as, tornandoas anérgicas ou altas produtoras de IL-10. No entanto, as interações entre DCs e células T 
reguladoras (Treg), caracterizadas pela expressão das moléculas CD4, CD25 e do fator de transcrição Foxp3, começaram a ser estudadas apenas recentemente.

Evidências da existência de células T com capacidade reguladora/supressora remontam ao final da década de 1960. A observação de que células $T$ originárias do timo apresentavam capacidade supressora foi feita em 1969 por Nishizuka e Sakakura. Estes pesquisadores observaram que após timectomia neonatal, camundongos fêmeas desenvolviam atrofia dos ovários. Mais, observou-se que a reconstituição do timo nesses animais alguns dias depois foi capaz de prevenir a doença. Esses estudos permitiram concluir que células derivadas do timo eram responsáveis pela supressão da doença. Portanto, ficou evidente que a eliminação de clones autoreativos no timo não era mecanismo único envolvido na tolerância ao próprio.

Os experimentos de Sakaguchi e cols. (1995) mostraram que as células T CD4 ${ }^{+}$ provenientes do baço e linfonodos de camundongos BALB/c, que não expressavam a molécula CD25 (cadeia a do receptor da IL-2), induziam o desenvolvimento de uma série de doenças auto-imunes quando transferidas para camundongos atímicos. Esse processo era revertido quando se transferiam concomitantemente linfócitos $\mathrm{T} \mathrm{CD} 4^{+} \mathrm{CD} 25^{+}$para esses camundongos. Estudos posteriores demonstraram que essas células, denominadas T reguladoras (Treg) eram originadas no timo e que apresentavam fenótipo muito similar ao de células T ativadas ou de memória (Itoh et al, 1999).

Algumas características imunológicas das células Treg as diferenciam das demais células T como, por exemplo, a baixa capacidade de proliferação frente a estímulos in vitro; a capacidade de suprimir respostas efetoras das células $\mathrm{T} \mathrm{CD}^{+}$e $\mathrm{T} \mathrm{CD}^{+}$(Suri-payer et al, 1998) através do contato celular (Thornton et al,1998; Takahashi et al, 1998). Além do mais, essas células expressam constitutivamente, no timo e na periferia, a molécula CTLA-4 (do inglês, Cytotoxic T Lymphocyte Antigen-4). (Read et al, 2000; Takahashi et al, 2000), através da qual estas células podem, possivelmente, exercer a sua função, e o receptor do fator de necrose tumoral induzido por glicocorticóide (GITR). O GITR, no timo, pode ter a 
função de proteger os timócitos da seleção negativa tornando a célula resistente a apoptose induzida pelo TCR (Nocentini et al, 1997; Gurney et al, 1999). Observações de Shimizu e cols. (2002) sugerem que, na periferia, a estimulação do GITR nas células Treg pode antagonizar seus efeitos supressores. Resultados obtidos por McHugh e cols. (2002) também sugerem que a ligação do GITR a seu ligante diminui a capacidade supressora das células Treg, possivelmente por um mecanismo que envolve a modulação da resposta destas células à IL-2. Uraushihara et al (2003) demonstraram, utilizando um modelo de colite induzido por transferência de células T naïve para camundongos SCID, que o tratamento com anticorpos anti-GITR não permite que a doença seja controlada pela co-transferência de uma população de células $T$ reguladoras, caracterizadas pela expressão da molécula CD4 e pela baixa expressão da molécula CD45RB. Dessa forma o papel fisiológico desse receptor pode estar correlacionado ao direcionamento da resposta imune quando da necessidade de padrões efetores, como no caso de infecções microbianas ou diante do aparecimento de células tumorais.

A demonstração de que as células Treg eram originadas do timo fez com que pesquisadores buscassem compreender quais eram os mecanismos envolvidos no processo de seleção tímica destas células. Jordan e cols. (2001), utilizando camundongos com receptores de células $T$ (TCR) específicos para um peptídio conhecido, demonstraram que as células Treg são selecionadas no timo ao reconhecerem peptídios com alta afinidade. A interação de alta afinidade entre o peptídio e o TCR no timo, portanto, pode induzir a geração de células Treg ao invés da deleção clonal. É importante notar que o processo de seleção das células Treg, neste modelo, é mediado por células tímicas resistentes à radiação. Recentemente (Aschenbrenner et al, 2007), foi demonstrado que a seleção de células Treg é mediada por células epiteliais da medula tímica. Além disso, os autores demonstraram que estas células epiteliais tímicas expressam a molécula AIRE (do inglês, Autolmmune REgulator), responsável pela expressão promíscua de antígenos periféricos no timo. 
A recente identificação de um gene expresso nas células $T$ reguladoras humanas e de camundongos facilitou a caracterização dessa subpopulação celular. Esse gene, que é exclusivamente expresso nas células T reguladoras, denominado Foxp3, transcreve para um fator de transcrição denominado "scurfin", e está ativado apenas nestas células (Hori et al, 2003; Khattri et al, 2003). Mutações no gene Foxp3 culminam no desenvolvimento de doenças linfoproliferativas fatais (Bennett et al, 2001; Wildin et al, 2002). Células T $\mathrm{CD}^{+}{ }^{+} \mathrm{CD} 25^{-}$transfectadas com Foxp3 foram capazes de prevenir o desenvolvimento de gastrite ou colite auto-imune quando transferidas para camundongos imunodeficientes (Hori et al, 2003). Estudos mais recentes, no entanto, indicam que em humanos o Foxp3 pode também ser expresso de maneira transiente por linfócitos T, CD4 e CD8, quando estes são ativados (Gavin, 2006).

Os estudos acerca do papel desempenhado pelo gene Foxp3 no desenvolvimento e função das células Treg foram aprofundados. Fontenot e cols. (2003) demonstraram que a deleção do gene Foxp3 em camundongos leva ao desenvolvimento espontâneo de doenças auto-imunes nestes animais. Os animais deficientes em Foxp3 apresentam maior número de células tanto no baço quanto nos linfonodos. Além disso, os linfócitos T CD4 ${ }^{+}$destes animais apresentam um fenótipo característico de células ativadas. A ativação exacerbada dos linfócitos $\mathrm{T} \mathrm{CD}^{+}$se correlacionava com o desenvolvimento de inflamação generalizada e a morte dos camundongos com aproximadamente 4 semanas de vida. Os autores demonstraram também que a ausência de Foxp3 impede o desenvolvimento de células Treg nestes animais. Um ponto importante ressaltado neste trabalho é a demonstração de que as células T CD4+ naïve presentes nos camundongos deficientes em Foxp3 não possuem uma capacidade intrínseca maior de proliferação. Sendo assim, estes dados sugerem fortemente que a expressão de Foxp3 é fundamental tanto para o desenvolvimento quanto para a função das células Treg, e que sua função não está relacionada diretamente no controle da ativação dos linfócitos T CD4 naïve. Além disso, recentemente foi demonstrado que a permanência das células $\mathrm{CD}^{+} \mathrm{CD}_{2} 5^{+} \mathrm{Foxp}^{+}$na periferia de camundongos adultos é 
essencial para que não haja desenvolvimento de auto-imunidade (Kim et al, 2007). Estes dados dão suporte à visão de que a supressão mediada por estas células é importante não só durante o período neonatal, onde há uma taxa aumentada de proliferação homeostática pelos linfócitos $\mathrm{T}$ recém saídos do timo, mas que ela é ativa e essencial durante a vida adulta.

A observação de que camundongos deficientes em IL-2 ou em subunidades do receptor da IL-2 (Sadlack et al, 1993; Suzuki et al, 1995) desenvolvem espontaneamente doenças auto-imunes, instigou pesquisadores a buscar uma possível correlação entre esta citocina e o desenvolvimento e função das células Treg. No entanto, a identificação das células Treg pela expressão do marcador CD25 dificultava esta análise, uma vez que esta molécula é também expressa por linfócitos $T$ ativados, presentes em grandes quantidades nos camundongos deficientes nas moléculas citadas acima. $O$ desenvolvimento de camundongos em que a expressão de Foxp3 era ligada à expressão de uma molécula fluorescente, denominada "green fluorescent protein" (GFP), permitiu a análise exata da presença de células Treg nos animais deficientes em IL-2 ou componentes de seu receptor. Estes estudos demonstraram que a geração de células Treg estava apenas modestamente diminuída nestes animais. Além disso, estas células eram tão competentes quanto as células presentes em animais selvagens em suprimir a proliferação de linfócitos T naïve. No entanto, a capacidade destas células proliferarem, ou sobreviverem, na periferia é diminuída nos camundongos deficientes em IL-2 ou componentes do receptor da IL-2, sugerindo este fato como o responsável pelo desenvolvimento da auto-imunidade nestes animais (Fontenot et al, 2005).

Mais recentemente, Burchill e cols. (2007) demonstraram que a sinalização pela cadeia $\beta$ do receptor da IL-2 é necessária para que células Treg se desenvolvam. As cadeia $\beta$ e $\gamma_{c}$ do receptor da IL-2 são compartilhadas pelos receptores da IL-2 e da IL-15. Utilizando animais geneticamente modificados os autores demonstraram que na ausência de IL-2 e IL-15 concomitantemente não há geração de células Treg. Por outro lado, na ausência de apenas 
uma das citocinas ainda há geração de células Treg, sugerindo uma ação redundante das mesmas. Mais, os autores demonstraram ainda que a sinalização pela cadeia $\beta$ do receptor da IL-2 pode ser importante para a expressão de Foxp3, uma vez que esta via ativa o fator de transcrição STAT-5 que se liga a regiões presentes no promotor do gene Foxp3.

Os mecanismos de supressão utilizados pelas células Treg ainda não foram totalmente elucidados, sendo ainda um campo de debate no tocante à biologia destas células. É amplamente aceita a idéia de que, para exercer suas funções reguladoras, as células Treg precisam estar em contato com as células respondedoras. No entanto, há dados sugerindo que as células Treg exercem seus efeitos supressores através de citocinas, principalmente IL-10 (Maloy et al, 2003) ou TGF- $\beta$ (Zhang et al, 2001; Levings et al, 2002). Todavia, na época em que estes estudos foram conduzidos ainda não se havia identificado o fator de transcrição Foxp3 e as células Treg eram caracterizadas pela expressão das moléculas CD4 e CD25. Sendo assim, é possível que os estudos implicando a ação de citocinas como mecanismo regulador empregado pelas células Treg reflitam a ação de outras populações de células $T$ com capacidade reguladora porém, distintas das células $T$ reguladoras identificadas pela expressão das moléculas CD4, CD25 e do fator de transcrição Foxp3. No entanto, a questão da dependência de citocinas para a função supressora das células Treg ainda é tema de debate. Recentemente, utilizando um modelo de colite, Uhlig e cols. (2006) demonstraram a presença de células $\mathrm{CD} 4^{+} \mathrm{CD} 25^{+} \mathrm{Foxp}^{+}$produtoras de IL-10 na lâmina própria de camundongos doentes.

Os mecanismos pelos quais as células Treg exercem sua função supressora através do contato célula-célula também são controversos na literatura. Nakamura et al reportaram em 2001 que o efeito supressor das células Treg se devia à expressão de uma forma de TGF- $\beta$ ligada à membrana. No entanto, estes achados não foram confirmados posteriormente nem em células Treg de camundongos (Piccirillo et al, 2002) nem em clones de células Treg humanas (Levings et al, 2002). 
Outra molécula apontada de maneira recorrente como responsável pela supressão mediada por contato realizada pelas células Treg é a molécula CTLA-4. Read e cols. (2000) demonstraram que o bloqueio de CTLA-4 revertia o efeito protetor das células CD $4^{+}$CD $25^{+}$ em um modelo experimental de colite. No entanto, o mesmo grupo de pesquisa utilizando o mesmo modelo de experimental de colite, demonstrou que linfócitos $\mathrm{T} C D 4^{+} \mathrm{CD} 25^{+}$ derivados de camundongos deficientes em CTLA-4 mantém sua capacidade de prevenir o desenvolvimento da doença. Os autores sugerem que esta discrepância ocorre devido ao desenvolvimento de mecanismos de supressão compensatórios pelas células Treg derivadas dos camundongos deficientes em CTLA-4 (Read et al, 2006). Os mesmo resultados acerca das células Treg derivadas de camundongos deficientes em CTLA-4 foram obtidos anteriormente por Tang e cols. (2004).

Um dos mecanismos propostos para explicar o efeito supressor mediado pelo CTLA-4 envolve sua interação com as moléculas CD80 e CD86 em células dendríticas. Fallarino et al (2003) reportaram que a ligação de CTLA-4 às moléculas co-estimuladoras CD80 e CD86 em DCs induz a expressão da enzima indolamina-2,3-dioxigenase (IDO). Esta enzima é capaz de depletar o aminoácido essencial triptofano e liberar produtos de sua degradação, chamados de quinureninas. Estes eventos, em conjunto, seriam capazes de inibir a proliferação dos linfócitos T.

O trabalho realizado por Paust e cols. (2004) sugere, porém sem demonstrar formalmente, a importância da interação entre CTLA-4 e as moléculas CD80 e CD86. Neste trabalho, os autores demonstram que a expressão de CD80 e CD86 nas células T respondedoras é essencial para que as células Treg possam suprimir a proliferação das primeiras. Sabendose que o CTLA-4 se liga a estas moléculas, os autores sugerem que as interações entre os linfócitos T respondedores e as células Treg responsáveis pela supressão da proliferação são mediadas por estas moléculas.

Estudos realizados utilizando a técnica de microscopia intravital de dois fótons trouxeram importantes informações sobre o funcionamento das células Treg in vivo. Dois estudos 
independentes (Tang et al, 2006; Tadokoro et al, 2006) demonstraram que a presença de células Treg impede que os linfócitos $\mathrm{T} \mathrm{CD4}^{+}$naïve estabeleçam contatos estáveis com as células dendríticas. O bloqueio da formação de contatos estáveis parece ocorrer através de uma interação entre as células Treg e a as células dendríticas que apresentam o antígeno. Apesar de os trabalhos serem mais descritivos do que mecanísticos, a utilização desta técnica se apresenta como uma ferramenta importante para futuros estudos visando identificar o(s) mecanismo(s) pelo(s) qual( is) as células Treg exercem seu efeito supressor in vivo.

A demonstração de que as células Treg se originam no timo (Itoh et al, 1999) atrelada às demonstrações de que estas células são anérgicas quando estimuladas in vitro, levantaram a questão a respeito da manutenção desta subpopulação na periferia após a involução tímica. Uma das primeiras demonstrações de que o comportamento das células Treg in vivo era diferente do comportamento observado in vitro foi dada por Walker e cols. (2003). Neste trabalho, os autores evidenciam a proliferação de células Treg obtidas de camundongos com TCR transgênicos, capazes de reconhecer um peptídio da ovalbumina (OVA). Quando os linfócitos $\mathrm{T} \mathrm{CD} 4^{+} \mathrm{CD} 25^{+}$destes camundongos eram transferidos para outro animal que, por sua vez, era imunizado com OVA, observou-se que as células Treg específicas para OVA proliferavam. No entanto, a proliferação destas células não induzia a produção de IFNY, IL-2, IL-4, IL-10 ou o aumento da expressão de CD40L em sua superfície. Mais, os autores demonstraram também que após a proliferação estas células não perdiam sua capacidade supressora. Kretschmer e cols. (2005) obtiveram resultados semelhantes com respeito à expansão de células Treg após imunização. Os autores demonstram que as células Treg de camundongos que possuem TCR transgênicos para um peptídio da hemaglutinina (HA) são capazes de proliferar após imunização subcutânea com o peptídio cognato.

Outra possibilidade para a manutenção da população de células Treg na periferia é a geração de células $\mathrm{CD}^{+}{ }^{+} \mathrm{CD} 25^{+}{ }^{+} \operatorname{oxp}^{+}$a partir de células T CD4 ${ }^{+} \mathrm{CD} 25^{-}$. Apostolou e von 
Boehmer (2004), utilizando um sistema em que pequenas doses de antígeno são liberadas a partir de uma bomba osmótica instalada subcutaneamente em camundongos, demonstraram que a conversão de linfócitos $\mathrm{T}$ naïve em células Treg acontecia in vivo. Neste sistema, os autores utilizaram um camundongo com TCR transgênico capaz de reconhecer um peptídio de HA. Portanto, ainda havia a possibilidade de que a conversão de células $\mathrm{T} \mathrm{CD}^{+}$em células Treg não ocorreria em camundongos com um repertório de linfócitos $T$ policlonal. Utilizando populações de linfócitos $T$ naïve obtidas a partir de camundongos C57BL/6 selvagens, Liang e cols. (2005) demonstraram que estas células convertem-se em células Treg quando transferidas para camundongos congênicos irradiados ou não. Os autores demonstraram também que a conversão observada é timo independente porém, é dependente das moléculas CD80 e CD86.

Lafaille et al (2004) demonstraram que após a transferência de linfócitos T naïve para camundongos transgênicos que não possuem células Treg provenientes do timo, há o surgimento de uma população $C D 4^{+} \mathrm{CD} 25^{+} \mathrm{Foxp} 3^{+}$na periferia. Esta população é anérgica, e possui fenótipo e propriedades funcionais iguais às das células Treg provenientes do timo. Em outro trabalho do mesmo grupo, Mucida e cols. (2005) utilizando o mesmo modelo de camundongos transgênicos, demonstraram que a indução de tolerância oral nestes camundongos leva ao surgimento de células Treg na periferia. Como no trabalho anterior, estas células possuem todas as características de células Treg, como a expressão de CD4, CD25 e Foxp3, além da capacidade de suprimir respostas imunes de maneira antígeno específica in vivo e in vitro. Neste trabalho foi demonstrado também que a geração destas células é dependente de TGF- $\beta$. Recentemente, foi demonstrado que a geração de células Treg a partir de células $\mathrm{CD}^{+}$naïve pela co-cultura destas com DCs esplênicas é aumentada significativamente na presença de TGF- $\beta$ (Luo et al, 2007). O aumento evidenciado é dose dependente, ou seja, quanto maior a dose de TGF- $\beta$ utilizada maior a taxa de conversão dos linfócitos T naïve em células Treg. De maneira importante, os autores demonstraram que 
estas células possuem capacidade supressora in vitro, além de serem capazes de impedir o desenvolvimento de diabetes do tipo I quando transferidas para camundongos NOD.

A idéia de que o TGF- $\beta$ é capaz de induzir a expressão de Foxp3 em células CD4 ${ }^{+}$CD25 e convertê-las em células Treg foi demonstrada por diferentes grupos e é amplamente aceita, apesar de não haver ainda um mecanismo capaz de explicar este fenômeno. No entanto, a demonstração de que a expressão de Foxp3 diminui a expressão de Smad-7 (um regulador negativo da sinalização pelo TGF- $\beta$ ) e aumenta a expressão de Smad-3 e 4 (reguladores positivos da sinalização pelo TGF- $\beta$ ), apóia a idéia de que a expressão de Foxp3 induz uma regulação positiva da sinalização por esta citocina e, desta forma, atua para estabilizar o fenótipo de células Treg geradas na periferia (Fantini et al, 2004).

Mais recentemente, as interações entre DCs e células Treg começaram a ser exploradas como uma maneira de explicar tanto a geração destas células a partir de linfócitos T naïve, quanto a expansão de Treg na periferia. Min e cols. (2003) demonstraram, em um modelo de transplante cardíaco, que as interações entre células dendríticas imaturas e células T reguladoras são importantes para a manutenção da tolerância ao órgão transplantado. Verificou-se também que as células dendríticas isoladas dos receptores que haviam aceitado o transplante eram capazes de induzir a geração de novas células Treg. Além disso, os resultados obtidos demonstram um aumento na população de células Treg nos camundongos que aceitaram o transplante e, o co-cultivo dessas células com células dendríticas de camundongos não estimulados foi capaz de gerar células dendríticas com propriedades reguladoras. Estes resultados sugerem uma regulação recíproca entre células dendríticas e células Treg. Cong e cols. (2005) demonstraram recentemente que células dendríticas impedidas de maturar-se são capazes de gerar células $T$ reguladoras Foxp3 positivas. Neste modelo, a geração de células T reguladoras é dependente da IL-10 produzida pelas DCs, porém o efeito supressor das células T reguladoras é dependente de contato e independente de IL-10 e TGF- $\beta$. 
Utilizando um modelo experimental diferenciado, em que antígenos são acoplados à região constante do anticorpo específico para DEC-205, um receptor endocítico expresso em DCs, Hawiger e cols. (2001) demonstraram que linfócitos T ao reconhecerem antígenos apresentados por DCs imaturas sofrem um processo de expansão clonal que dura em torno de 7 dias. No entanto, após este período grande parte dos linfócitos T antígeno específicos morrem, enquanto os poucos linfócitos $T$ antígeno específicos ainda encontrados na periferia não são capazes de responder a desafios posteriores com o mesmo antígeno. Estes resultados foram posteriormente expandidos demonstrando que este protocolo além de induzir a deleção de clones específicos, também é capaz de gerar células T reguladoras a partir de linfócitos T naïve (Kretschmer et al, 2005). Os autores demonstraram que a apresentação de antígenos por DCs imaturas é capaz de gerar células T CD $4^{+} \mathrm{CD} 25^{+} \mathrm{Foxp} 3^{+}$ in vivo a partir de linfócitos $\mathrm{T} \mathrm{CD}^{+} \mathrm{CD} 25^{-}$naïve. Os autores demonstraram também que quando as DCs são ativadas, utilizando-se anticorpo anti-CD40, não há geração de células Treg. Este trabalho também evidencia que, após a conversão dos linfócitos T CD4 ${ }^{+} \mathrm{CD} 25^{-}$ naïve em células Treg, estas células podem ser expandidas em condições imunogênicas, ou seja, condições em que as DCs estão maduras. Os dados apresentados mostram ainda que o número de divisões celulares realizadas pelos linfócitos $\mathrm{T}$ naïve é inversamente proporcional à conversão destas células em células Treg. Estes dados são corroborados por experimentos que demonstram que a presença de TGF- $\beta$ ou a ausência de IL-2, condições em que a proliferação dos linfócitos $T$ é reduzida, aumentam a taxa de conversão dos linfócitos T naïve em células Treg.

Em um modelo de indução de tolerância a aloantígenos, Ochando e cols. (2006) demonstraram o papel das células dendríticas plasmacitóides na geração de células Treg. Neste estudo os autores mostram que as pDCs são capazes de internalizar, processar e apresentar antígenos provenientes do órgão transplantado. Estas células então migram para os linfonodos, se acumulam na área de linfócitos T onde em contato com linfócitos T CD4 ${ }^{+}$ naïve geram células $\mathrm{CD} 4^{+} \mathrm{CD} 25^{+}$Foxp $3^{+}$. A geração de células Treg, neste contexto, é 
dependente de TGF- $\beta$, corroborando os dados de trabalhos citados anteriormente. Apesar disto, em nenhum dos trabalhos a célula produtora de TGF- $\beta$ foi identificada.

Estudos realizados utilizando-se células dendríticas derivadas da medula óssea de camundongos demonstraram que essas células são capazes de induzir a proliferação de células Treg na presença de antígeno (Yamazaki et al, 2003). Esta proliferação é mais pronunciada quando as DCs estão maduras e é parcialmente dependente de CD86. Este estudo também demonstra que as células Treg proliferam in vivo em resposta à apresentação de antígenos por DCs. Estes resultados foram expandidos pelo mesmo grupo, desta vez utilizando um modelo de diabetes auto-imune (Tarbell et al, 2004). Neste trabalho, células Treg foram expandidas pelo co-cultivo com DCs maduras e injetadas em camundongos NOD, que desenvolvem diabetes do tipo I espontaneamente. As células Treg injetadas foram capazes de suprimir o desenvolvimento de diabetes auto-imune nestes camundongos. Como no trabalho anterior, a expansão de células Treg por DCs foi também evidenciada in vivo. É importante notar que ambos os trabalhos foram realizados utilizando células Treg possuidoras de TCR transgênicos, e que a expansão das células Treg observada depende, pelo menos em parte, da presença de IL-2 na co-cultura. Recentemente, foi demonstrado que além de prevenir o desenvolvimento do diabetes do tipo I as células Treg geradas a partir da co-cultura com DCs eram capazes induzir melhora quando injetadas em camundongos já acometidos pela doença (Tarbell et al, 2007). De maneira interessante, nos camundongos em que houve melhora da doença foi observado um aumento do número de células Treg presentes no linfonodo pancreático. No entanto, as células encontradas não eram as células Treg injetadas previamente, e sim células Treg derivadas do camundongo recipiente. Estes dados sugerem que a presença de células Treg pode criar um ambiente propício ao desenvolvimento destas células, como forma de manter a tolerância na periferia.

O mesmo grupo demonstrou que quando co-cultivadas com DCs alogênicas as células Treg expandem-se, mantendo a expressão de Foxp3. A capacidade supressora da 
população expandida, no entanto, é maior do que a da população inicial. Os autores especulam que este fato possa ser resultado da expansão de clones de células Treg aloespecíficas (Yamazaki et al, 2006). Em conjunto estes trabalhos demonstram que a expansão de células Treg por DCs ocorre tanto in vitro quanto in vivo, e que após a expansão estas células mantêm suas características funcionais, ou seja, ainda são capazes de suprimir resposta imunes.

A tolerância periférica parece contar ainda com a ação de outros mecanismos para a sua manutenção, entre eles o efeito de células em apoptose no sistema imune. Alguns autores têm demonstrado que células em apoptose podem modular o sistema imune de forma a induzir tolerância. Utilizando um modelo de infusão intravenosa de células alogênicas em apoptose, Wang e cols (2006) demonstraram que células dendríticas que capturaram as células em apoptose são capazes de deletar clones de linfócitos T CD4. Os autores demonstraram também que esses clones são ativados pelas DCs que capturaram células alogênicas em apoptose, porém, após a ativação, não são capazes de aumentar a expressão da molécula anti-apoptótica $B c l-X_{L}$, ou os receptores para IL-7 e IL-15, citocinas essenciais para a sobrevivência de linfócitos T na periferia. Com a deleção dos clones há um aumento na sobrevida de transplantes cardíacos alogênicos. No entanto, este protocolo não é capaz de induzir indefinidamente o aceite de um coração alogênico transplantado. Apesar disso, o coração passa a ser aceito indefinidamente quando este protocolo é associado ao bloqueio da interação entre CD40 e CD40L. Os autores demonstraram que quando há infusão de células alogênicas em apoptose na presença do bloqueio há um aumento no número de células Treg específicas para o antígeno e que essas células são responsáveis pela manutenção da tolerância sistêmica ao antígeno. Em outro trabalho recente, Kleinclauss e cols (2006) demonstram que a infusão intravenosa de células em apoptose é capaz de expandir o número de células Treg em camundongos. Neste trabalho os autores demonstram também que este aumento é dependente de TGF- $\beta$. 
Sendo assim, apesar da grande quantidade de dados acerca da biologia das células dendríticas e das células T reguladoras, ainda não existem dados definitivos a respeito das conseqüências geradas pela interação entre estes dois tipos celulares. Com o intuito de compreendermos melhor alguns dos parâmetros envolvidos na alteração da população das células $\mathrm{T}$ reguladoras após seu contato com DCs, elaboramos um sistema in vitro no qual co-cultivamos células dendríticas diferenciadas a partir de células da medula óssea e células de linfonodos de camundongos BALB/c. A esse sistema incorporamos células alogênicas em apoptose como fonte de antígenos exógenos. É importante salientar que a escolha de células alogênicas em apoptose têm duas características importantes: (1) ser uma fonte de antígenos exógenos e (2) possuir reconhecida capacidade de modular o sistema imune e, assim, segundo alguns autores, induzir a geração de células Treg. O modelo experimental idealizado nos permite manipular parâmetros como o estado de ativação das DCs, a presença de antígenos exógenos e a presença de células Treg durante a co-cultura, permitindo-nos, assim, verificar o impacto de cada um desses componentes nas alterações ocorridas na população de células Treg após a co-cultura entre células de linfonodo e células dendríticas. 
2. Objetivos 


\section{Objetivos}

\subsection{Objetivo Geral}

Neste trabalho temos como objetivo avaliar as mudanças ocorridas na população de células $\mathrm{T}$ CD $4^{+} \mathrm{CD} 25^{+}$Foxp $3^{+}$após a co-cultura de células de linfonodo com células dendríticas.

\section{$\underline{2.2 \text { Objetivos Específicos }}$}

$\rightarrow$ Gerar células dendríticas a partir de células da medula óssea de camundongos;

$\rightarrow$ Caracterizar as células dendríticas obtidas fenotípica e funcionalmente;

$\rightarrow$ Analisar a população $\mathrm{CD} 4^{+} \mathrm{CD} 25^{+} \mathrm{Foxp}^{+}$após co-cultivo de células de linfonodo com células dendríticas maduras e imaturas, na presença ou ausência de antígenos alogênicos;

$\rightarrow$ Determinar a contribuição das células $\mathrm{T} \mathrm{CD} 4^{+} \mathrm{CD} 25^{+}$preexistentes no linfonodo para as mudanças ocorridas na população de células T $\mathrm{CD} 4^{+} \mathrm{CD} 25^{+} \mathrm{Foxp} 3^{+}$após a co-cultura com células dendríticas maduras e imaturas, na presença ou ausência de antígenos alogênicos. 
3. Materiais e Métodos 


\section{Materiais e Métodos}

\subsection{Animais}

Foram utilizados nos experimentos camundongos BALB/c $\left(\mathrm{H}-2^{\mathrm{d}}\right)$ e C57BL/6 $\left(\mathrm{H}-2^{\mathrm{b}}\right)$ fêmeas. Todos os animais foram obtidos no Biotério de Criação do Departamento de Imunologia do Instituto de Ciências Biomédicas da USP. Foram utilizados animais de 6 a 8 semanas em todos os experimentos, com exceção feita ao caso da obtenção de timócitos em que foram utilizados animais de 3 semanas. Todos os procedimentos realizados foram aprovados pela Comissão de Ética em Experimentação Animal (CEEA).

\subsection{Geração de células dendríticas}

Camundongos $B A L B / c$ fêmeas foram sacrificados em câmara de $\mathrm{CO}_{2}$ e tiveram seus fêmures e tíbias retiradas e colocadas em meio de cultura DMEM (Dubelcco's Modified Eagle's Médium - Sigma Chemical Co., St Louis, Mo, USA). As células da medula óssea foram retiradas com jatos de DMEM com auxílio de seringa de $1 \mathrm{ml}$ com agulha. As células obtidas foram centrifugadas, $450 \mathrm{~g}$ por 5 minutos, ressuspendidas em meio DMEM suplementado com $0,1 \mathrm{mM}$ de aminoácidos não essenciais, $0,1 \mathrm{mM}$ de vitaminas, $2 \mathrm{mM}$ de Lglutamina, $100 \mu \mathrm{g} / \mathrm{ml}$ de gentamicina, $0,05 \mathrm{mM}$ de 2-mercaptoetanol, $1 \mathrm{mM}$ de piruvato de sódio, todos da Gibco BRL (Rockville, USA) e 5\% de soro fetal bovino (Hyclone, USA). A concentração de células foi ajustada de modo a obter-se $2 \times 10^{6}$ células $/ \mathrm{ml}$, e foram adicionados $5 \mathrm{ml}$ dessa suspensão celular por poço, em placas de cultura de 6 poços (Sarstedt, Newton, NC, USA), obtendo-se o total de $1 \times 10^{7}$ células por poço. Foi adicionado a cada poço 10ng/ml de GM-CSF recombinante murino (Pharmigen, San Diego, Ca, USA). As células foram mantidas a $37^{\circ} \mathrm{C}$ em atmosfera úmida com $5 \%$ de $\mathrm{CO}_{2}$ por 7 dias. As células receberam nova dose de $10 \mathrm{ng} / \mathrm{ml}$ de GM-CSF no quarto dia de cultura em $4 \mathrm{ml}$ de meio fresco. Onde indicado as células dendríticas foram estimuladas no sexto dia com $1 \mu \mathrm{g} / \mathrm{ml}$ 
de LPS (Sigma Chemical Co., St. Louis, MO, EUA). O protocolo utilizado é descrito esquematicamente abaixo.

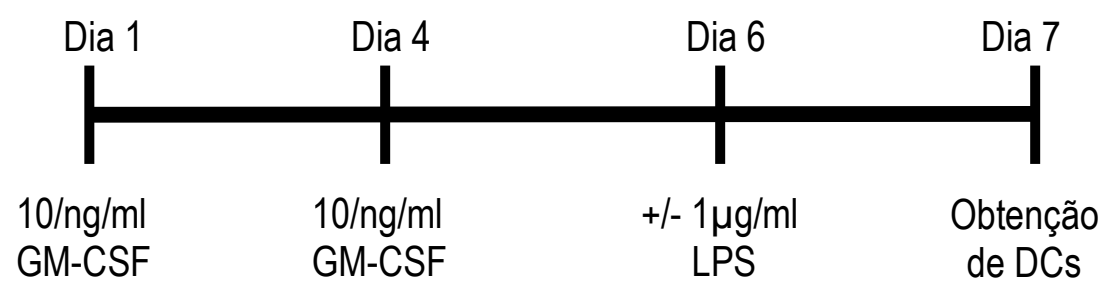

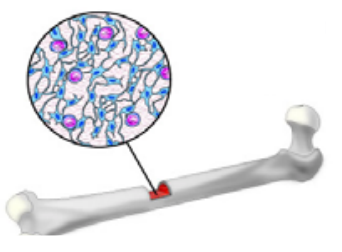

Obtenção de células da medula óssea
$+10 \mathrm{ng} / \mathrm{ml}$ de GM-CSF

(dia 1 e dia 4)
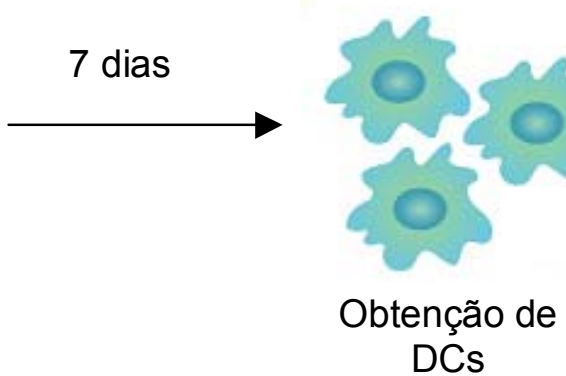

\subsection{Citometria de fluxo}

Para avaliar a expressão de moléculas de superfície, as células obtidas foram incubadas com $80 \mu$ l de sobrenadante de cultura do hibridoma $24 G 2$ contendo anticorpos anti-CD16/32 (bloqueador do receptor $\mathrm{Fc}$ ) durante trinta minutos a $4^{\circ} \mathrm{C}$. A seguir, as células foram incubadas com anticorpos monoclonais conjugados com fluorocromo (FITC, PE ou Cy) específicos para as moléculas de superfície de interesse por 30 minutos. Foram utilizados os seguintes anticorpos monoclonais para a marcação das células dendríticas: anti-CD11c-PE $\left(0,5 \mu \mathrm{g} / 10^{6}\right.$ células), anti-CD8-FITC $\left(0,5 \mu \mathrm{g} / 10^{6}\right.$ células $)$, anti-CD40-FITC $\left(0,5 \mu \mathrm{g} / 10^{6}\right.$ células $)$, anti-CD80-FITC $\left(0,5 \mu \mathrm{g} / 10^{6}\right.$ células), anti-CD86-FITC $\left(0,5 \mu \mathrm{g} / 10^{6}\right.$ células), anti-CD4-FITC $\left(0,5 \mu \mathrm{g} / 10^{6}\right.$ células), anti-B220-FITC $\left(0,5 \mu \mathrm{g} / 10^{6}\right.$ células $)$, anti-CD11b-FITC $\left(0,5 \mu \mathrm{g} / 10^{6}\right.$ células $)$ 
e anti-MHC classe II (I-A $\left.A^{d}\right)$-FITC $\left(0,5 \mu \mathrm{g} / 10^{6}\right.$ células). Como controle isotípico foram utilizados anticorpos do mesmo isótipo contra antígenos não relacionados conjugados aos respectivos fluorocromos. Foram utilizados os anticorpos monoclonais dos seguintes isótipos: lgG2a e lgG2b de rato e lgG1 e lgG2 de hamster.

Para a análise da expressão de Foxp3 intracelular pelas células T CD4 ${ }^{+} \mathrm{CD} 25^{+}$utilizamos o "kit" comercial "PE anti-mouse/rat Foxp3" (eBioscience, San Diego, CA, EUA). As células foram marcadas com anticorpos monoclonais anti-CD4-Cy $\left(0,5 / 10^{6}\right.$ células), anti-CD25-FITC $\left(0,5 \mu \mathrm{g} / 10^{6}\right.$ células), utilizando o mesmo protocolo descrito acima para a marcação das células dendríticas. Após a marcação dos receptores de superfície CD4 e CD25 as células foram fixadas e permeabilizadas de acordo com as orientações do fabricante. Após este processo, as células foram marcadas com anticorpo monoclonal anti-Foxp3-PE (clone FJK16s) $\left(0,75 \mu \mathrm{g} / 10^{6}\right.$ células). Após o período de incubação, as amostras foram lavadas com PBS contendo $3 \%$ de soro fetal bovino (SFB) e ressuspendidas em $300 \mu$ l do mesmo tampão. A aquisição e análise das amostras foram realizadas em citômetro de fluxo FACScalibur (Becton \& Dickinson, Mountain View, CA), utilizando-se o software CellQuest (Apple). Foram adquiridos 50.000 eventos $\mathrm{CD}^{+}$em cada uma das amostras.

\subsection{Cultura leucocitária mista utilizando células dendríticas como células estimuladoras}

Células dendríticas foram geradas a partir da medula óssea de camundongos BALB/c, conforme protocolo descrito acima. As DCs obtidas foram estimuladas ou não com $1 \mu \mathrm{g} / \mathrm{ml}$ de LPS durante 24 horas. Após este período as células dendríticas foram irradiadas com 3000 rad e plaqueadas em placa de 96 poços fundo "U" (Costar, Cambridge, MA, USA) em diferentes concentrações.

Baços de camundongos C57BL/6 foram retirados e individualmente macerados em meio DMEM. Após a lavagem (450g por 5 minutos), as hemácias do baço foram eliminadas com solução 0,83\% tris-amônio clorídrico (tampão de lise) por 4 minutos à temperatura ambiente, 
sendo as células posteriormente lavadas com PBS. As células foram ressuspendidas em meio DMEM suplementado, contadas e $5 \times 10^{5}$ células foram adicionadas aos poços contendo DCs.

A cultura foi mantida por 2,3 ou 4 dias em atmosfera úmida a $37^{\circ} \mathrm{C}$ contendo $5 \%$ de $\mathrm{CO}_{2}$. Foi adicionado à cultura $0,5 \mu \mathrm{Ci}$ de $\mathrm{H}^{3}$-timidina por poço 18 horas antes do término da cultura. A proliferação foi analisada pela incorporação de $\mathrm{H}^{3}$-timidina, lida em contador $\beta$ em contagens por minuto (CPM).

\subsection{Obtenção de células apoptóticas}

Foram obtidos timos de camundongos C57BL/6 fêmeas de 3 semanas de idade. Os timos foram macerados e as células contadas. A suspensão celular foi plaqueada em placas de 6 poços numa concentração de $1 \times 10^{7}$ células $/ \mathrm{ml}$. Adicionou-se a cada um dos poços $10^{-7} \mathrm{M}$ de dexametasona. As células foram mantidas em atmosfera úmida a $37^{\circ} \mathrm{C}$ contendo $5 \%$ de $\mathrm{CO}_{2}$. Após 4 horas as células foram lavadas com $50 \mathrm{ml}$ de meio DMEM para a completa remoção da dexametasona. Após a incubação, $1 \times 10^{6}$ células foram centrifugadas a $240 \mathrm{~g}$ por 5 min e lavadas uma vez em tampão HEPES (10 mM HEPES, 150mM NaCl, 5mM KCl, $1 \mathrm{mM} \mathrm{MgCl} 2$ e $1,8 \mathrm{mM} \mathrm{CaCl}_{2}$ ). Em seguida, as células foram ressuspendidas em $100 \mu \mathrm{L}$ de tampão HEPES, contendo quantidade apropriada de Anexina V-FITC, e incubadas por 20 min no escuro, à temperatura ambiente. Adicionou-se posteriormente $350 \mu$ de tampão HEPES e $40 \mu$ de uma solução de iodeto de propídeo a $100 \mu \mathrm{g} / \mathrm{ml}$ em tampão HEPES. A análise por citometria de fluxo foi feita imediatamente.

Em outros ensaios, para fins de padronização do protocolo, as células depois de lavadas (com $50 \mathrm{ml}$ de meio DMEM) foram incubadas por mais 2 ou 4 horas em atmosfera úmida a $37^{\circ} \mathrm{C}$ contendo $5 \%$ de $\mathrm{CO}_{2}$. Após este período adicional, as células foram marcadas com Anexina-V-FITC e iodeto de propídeo (PI), como descrito acima, e analisadas por citometria de fluxo. 


\subsection{Análise de apoptose via conteúdo de DNA (HFS)}

Foram obtidas $5 \times 10^{5}$ células de cada poço após os diferentes tempos de tratamento com dexametasona (conforme descrito no item 3.5). As células foram centrifugadas a $300 \mathrm{~g}$ por 5 $\min$ a $4^{\circ} \mathrm{C}$ e ressuspendidas em $300 \mu \mathrm{l}$ de tampão hipotônico HFS contendo $0,1 \%$ de TritonX100, 0,1\% de citrato de sódio e $50 \mu \mathrm{g} / \mathrm{ml}$ de iodeto de propídeo (PI). O conteúdo de DNA produziu um perfil gráfico dependente da fase do ciclo celular em que estas se encontravam. Foram considerados eventos apoptóticos os núcleos hipodiplóides, que no gráfico aparecem à esquerda do pico G0-G1. Foram analisados 10.000 eventos por replicata. Foi delimitada uma região utilizando-se os parâmetros de tamanho (FSC) e granulosidade (SSC) para a exclusão de debris.

\subsection{Ensaios de fagocitose}

Células dendríticas derivadas a partir de células da medula óssea de camundongos BALB/c (tratadas ou não com $1 \mu \mathrm{g} / \mathrm{ml}$ de LPS, por 24 horas) foram obtidas como descrito anteriormente. $4 \times 10^{4}$ células dendríticas foram incubadas em tubos plásticos "eppendorf" $(1,5 \mathrm{ml})$ com diferentes quantidades de timócitos alogênicos em apoptose. Os timócitos alogênicos em apoptose foram obtidos a partir de timos de camundongos C57BL/6 e adicionados às DCs de modo a obtermos as proporções de 1:1, 1:5 e 1:10 (DCs: timócitos alogênicos em apoptose) num volume final de $200 \mu$ de meio DMEM suplementado. As células foram mantidas em contato durante 2 e 4 horas. Após esse período as células foram lavadas com PBS e citocentrifugadas (“Citocentrífuga BIO Research") a 500 rpm por 4 minutos. A seguir as lâminas foram coradas utilizando-se o "Kit Hema 3" (Biochemical Sciences Inc., Swedesboro, NJ) e a fagocitose foi determinada por microscopia ótica. Um total de 300 células dendríticas foi analisado por lâmina. 


\subsection{Análise da produção de citocinas pelas células dendríticas}

Para a dosagem de citocinas as células dendríticas foram retiradas da placa de 6 poços (Sarstedt, Newton, NC, USA) no sexto dia de cultura e $5 \times 10^{5}$ DCs foram replaqueadas em placas de 96 poços (Corning, NY, EUA). Estas células foram mantidas sem estímulo, estimulados com $1 \mu \mathrm{g} / \mathrm{ml}$ de LPS ou incubadas com $2,5 \times 10^{6}$ células alogênicas em apoptose. Alternativamente, as DCs foram estimuladas com $1 \mu \mathrm{g} / \mathrm{ml}$ de LPS e incubadas com células alogênicas em apoptose. Após 24 horas os sobrenadantes da cultura foram retirados e estocados a $-20^{\circ} \mathrm{C}$ até o momento da dosagem de citocinas. O protocolo utilizado para obtenção dos sobrenadantes é demonstrado esquematicamente abaixo.

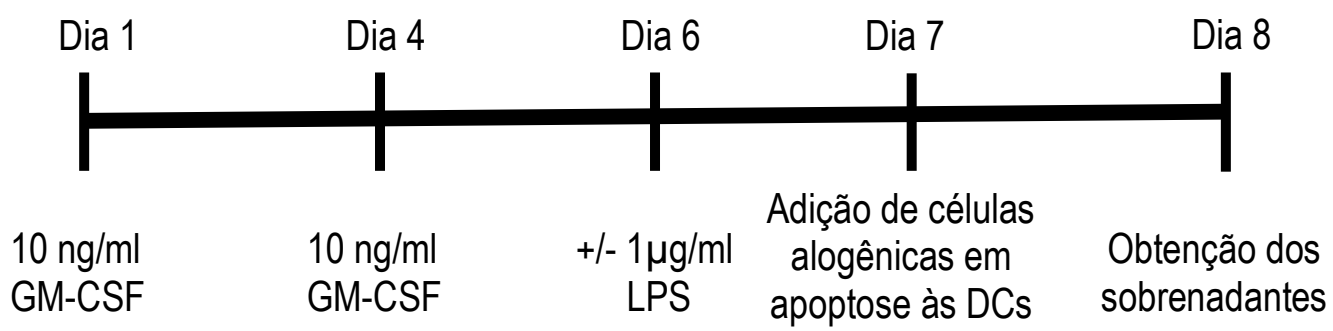

A análise da produção de IL-10, TNF- $\alpha$ e IL-12 foi realizada utilizando-se o "kit" comercial BD OptEIA da BD Biosciences (San Diego, CA, EUA). O protocolo utilizado para a dosagem destas citocinas foi o mesmo (descrito abaixo), variando-se apenas a concentração inicial utilizada para a obtenção da curva padrão de cada uma das citocinas.

Placas duras com propriedade de alta ligação (Corning, NY, EUA) foram sensibilizadas com $100 \mu \mathrm{l}$ do anticorpo de captura diluído em tampão carbonato/bicarbonato $(\mathrm{pH} \mathrm{9,6)} \mathrm{por}$ 16 horas à $4^{\circ} \mathrm{C}$. Após esse período, os poços foram bloqueados por 2 horas com $150 \mu \mathrm{l}$ de PBS contendo $0,05 \%$ de Tween 20 (PBS-T) e 5\% de leite em pó desnatado. Após o bloqueio, as placas foram lavadas 3 vezes com PBS-T e em cada poço foram adicionados $100 \mu \mathrm{l}$ das amostras ou do recombinante murino (IL-10 ou TNF $\alpha$ ) em diluições seriadas a partir de $4000 \mathrm{pg} / \mathrm{ml}$ para TNF- $\alpha$ e IL-12, e $2000 \mathrm{pg} / \mathrm{ml}$ para IL-10 em meio DMEM 
suplementado. As placas foram incubadas por 3 a 4 horas à temperatura ambiente e após o período de incubação, foram realizadas 3 lavagens com PBS-T. Aos poços foram adicionados $100 \mu \mathrm{l}$ de uma solução contendo o anticorpo de detecção biotinilado e estreptoavidina conjugada à peroxidase, incubado-se por um período de 2 horas à temperatura ambiente. As placas foram lavadas três vezes com PBS-T e $100 \mu$ da solução TMB (Pharmigen, San Diego, USA), foi adicionado a cada poço, seguido de 30 minutos de incubação à temperatura ambiente no escuro. A reação foi interrompida pela adição de $50 \mu \mathrm{l}$ de solução $1 \mathrm{M}$ de $\mathrm{H}_{3} \mathrm{PO}_{4}$. A leitura foi realizada em espectrofotômetro a 450nm.

A dosagem de TGF- $\beta$ foi realizada utilizando-se 0 "kit" comercial "TGF- $\beta_{1} E_{\text {MAX }}$ Immunoassay System" (Promega, Madison, WI, EUA) segundo protocolo descrito abaixo.

Placas duras com propriedade de alta ligação (Corning, NY, EUA) foram sensibilizadas com $100 \mu \mathrm{l}$ do anticorpo de captura diluído em tampão carbonato/bicarbonato $(\mathrm{pH} \mathrm{9,6)} \mathrm{por}$ 16 horas à $4^{\circ} \mathrm{C}$. Após este período, a placa foi lavada 3 vezes com tampão de lavagem (20mM Tris-HCL, $150 \mathrm{mM} \mathrm{NaCl}, 0,05 \%$ Tween 20). Os poços foram então bloqueados, incubando-se $200 \mu$ l por poço do tampão "TGF- $\beta$ Block Buffer", fornecido pelo fabricante, durante 1 hora à temperatura ambiente. Os poços foram lavados 3 vezes com tampão de lavagem e em cada poço foram adicionados $100 \mu \mathrm{l}$ das amostras ou do recombinante TGF- $\beta$ em diluições seriadas a partir de 4000 pg/ml em meio DMEM suplementado. Cada $50 \mu l$ das amostras provenientes dos sobrenadantes de culturas foram tratados com $1 \mu \mathrm{l}$ de $\mathrm{HCl} 1 \mathrm{~N}$ durante 15 minutos e, posteriormente, neutralizados com $1 \mu \mathrm{l}$ de $\mathrm{NaOH} 1 \mathrm{~N}$, antes de serem adicionados à placa. Esse tratamento é necessário para que o TGF- $\beta$ inativo seja convertido em sua forma ativa, reconhecida pelos anticorpos presentes no "kit". As amostras foram incubadas durante 2 horas à temperatura ambiente e lavadas 3 vezes com tampão de lavagem. Após as lavagens, foram adicionados $100 \mu$ por poço do anticorpo secundário antiTGF- $\beta$ (diluído 1:1000 no tampão "TGF- $\beta$ sample Buffer", fornecido pelo fabricante) e incubou-se a placa por 2 horas à temperatura ambiente. Novamente, após o período de incubação, a placa foi lavada 3 vezes com tampão de lavagem. A seguir, foram adicionados 
$100 \mu l$ por poço do anticorpo de detecção conjugado à peroxidase ( diluído 1:100 no tampão "TGF- $\beta$ sample Buffer", fornecido pelo fabricante). A placa foi incubada por 2 horas à temperatura ambiente. Em seguida, a placa foi lavada 3 vezes com tampão de lavagem e $100 \mu \mathrm{l}$ da solução TMB (Pharmigen, San Diego, USA), foi adicionado a cada poço, seguido de 30 minutos de incubação à temperatura ambiente no escuro. A reação foi interrompida pela adição de $50 \mu$ l de solução $1 \mathrm{~N}$ de $\mathrm{HCl}$. A leitura foi realizada em espectrofotômetro a $450 \mathrm{~nm}$.

Os limites de detecção nos ensaios realizados foram de $62,5 \mathrm{pg} / \mathrm{ml}$ para as dosagens TNF- $\alpha$, IL-12 e TGF- $\beta$ e de $31,25 \mathrm{pg} / \mathrm{ml}$ para as dosagens de IL-10.

\subsection{Co-cultura de células dendríticas com células de linfonodo}

As células dendríticas obtidas (tratadas ou não com $1 \mu \mathrm{g} / \mathrm{ml}$ de LPS, por 24 horas) foram incubadas com $1 \times 10^{7}$ timócitos alogênicos (C57BL/6 H-2 ${ }^{b}$ ) em apoptose (proporção 1:5 célula dendrítica: timócitos alogênicos em apoptose). A porcentagem de células em apoptose foi determinada por citometria de fluxo antes de serem adicionadas à cultura de células dendríticas. Foram utilizadas apenas as suspensões celulares com no mínimo 40\% de células em apoptose (Anexina-V-FITC ${ }^{+} \mathrm{PI}^{-}$). Dezoito horas depois as DCs foram lavadas com meio DMEM e foram adicionadas à cultura $1 \times 10^{7}$ células de linfonodo singênico (proporção 1:5 célula dendrítica:célula linfóide). Alternativamente, as células de linfonodo singênico foram depletadas de células $\mathrm{CD} 4^{+} \mathrm{CD} 25^{+}$antes de serem adicionadas à co-cultura. O protocolo utilizado é esquematizado abaixo.

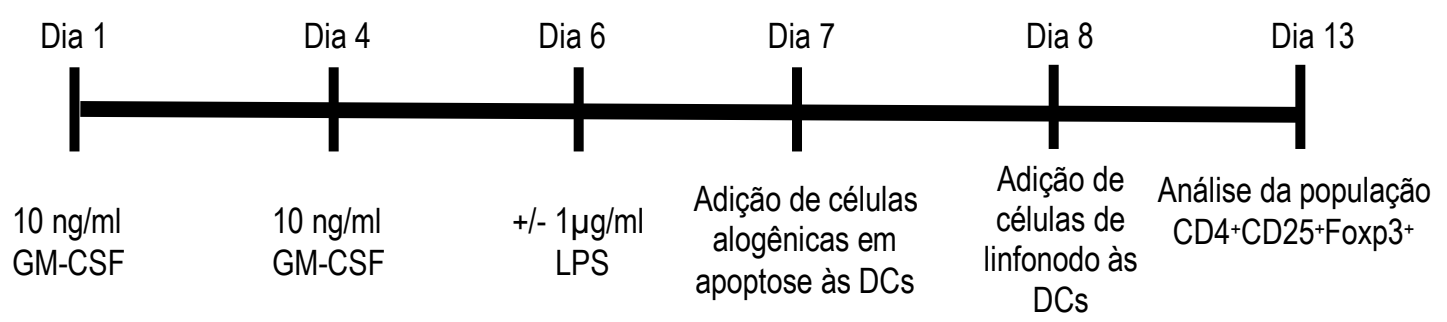




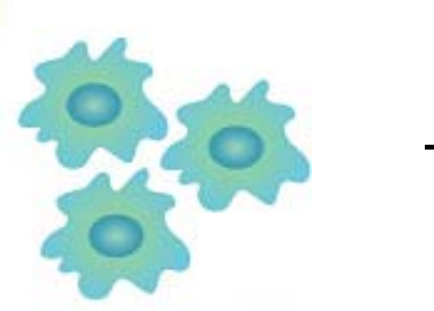

DCs

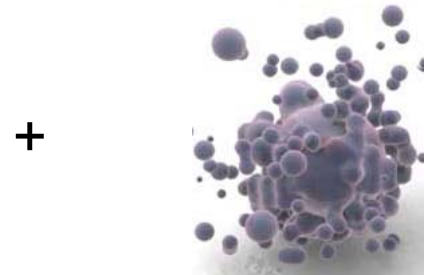

Células alogênicas em apoptose
18 horas

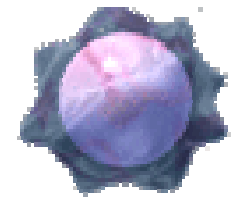

Análise das células $T$ reguladoras por citometria de fluxo
5 dias

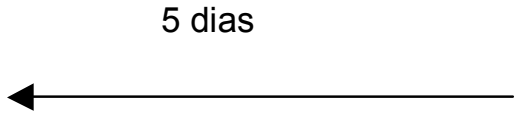

Adição de células de linfonodo às DCs

\subsection{Isolamento de células $C D 4^{+} C D 25^{+}$}

Para o isolamento das células $\mathrm{CD}^{+} \mathrm{CD} 25^{+}$foram utilizados anticorpos monoclonais acoplados a esferas magnéticas fornecidas no "kit" comercial "CD4 ${ }^{+} \mathrm{CD} 25^{+}$Regulatory T Cell Isolation Kit" (Miltenyi Biotec Inc, Auburn, CA, EUA), conforme protocolo sugerido pelo fabricante e descrito brevemente a seguir.

A separação de células $\mathrm{CD} 4^{+} \mathrm{CD} 25^{+}$se dá em duas etapas. Na primeira etapa são obtidas células $\mathrm{CD}^{+}$, enquanto todas as outras populações celulares presentes nos linfonodos, que foram marcadas previamente com anticorpos conjugados às esferas magnéticas, são retidas em colunas magnéticas submetidas a um campo magnético.

Obtida a fração de células CD4 ${ }^{+}$, essas células são marcadas com anticorpos anti-CD25 conjugados à esferas magnéticas. As células são submetidas novamente à passagem por coluna magnética submetida a um campo magnético. Desta forma, as células $C D 4^{+} \mathrm{CD} 25^{+}$ 
são retidas na coluna e obtém-se a fração de células $C D 4^{+} C D 25^{\circ}$. Para a obtenção da fração $\mathrm{CD} 4^{+} \mathrm{CD} 25^{+}$a coluna é retirada da influência do campo magnético e as células são eluidas da coluna com ajuda de um êmbolo próprio para a coluna em questão. Após a obtenção das frações $C D 4^{+} \mathrm{CD} 25^{+}$e $C D 4^{+} \mathrm{CD} 25^{-}$a pureza das mesmas foi determinada por citometria de fluxo.

\subsection{Análise estatística}

As análises estatísticas foram realizadas com o auxílio do software computacional Graphpad Prism (Graphpad Software Incorporation) versão 4.0. Os testes usados foram o ANOVA, seguido pelo teste Tukey, ou teste de Mann-Whitney. Valores de $p<0,05$ foram considerados estatisticamente significativos. Os dados foram apresentados como média \pm desvio padrão. 
4. Resultados 


\section{Resultados}

\subsection{Caracterização fenotípica das células dendríticas}

As células dendríticas constituem uma população altamente heterogênea que pode ser subdividida em diferentes subpopulações. Todas as subpopulações expressam a molécula CD11c e podem ser caracterizadas pela expressão diferencial das moléculas CD4, CD8, B220 e CD11b (Shortman \& Liu, 2002). Com o intuito de caracterizarmos a subpopulação obtida utilizando nosso protocolo de derivação de DCs, as células obtidas foram submetidas a análises por citometria de fluxo.

A figura $2 \mathrm{~A}$ mostra o perfil das células obtidas quanto à granulosidade (SSC) e ao tamanho (FSC). Observa-se que a maioria das células é grande e granulosa. Essa população foi determinada como a população de estudo para a verificação dos marcadores de subpopulação.

A análise das subpopulações foi realizada utilizando-se anticorpos anti-CD11c, -CD11b, CD4, -CD8 e -B220 (figuras 2 C, D, E e F). O gráfico da figura 2C mostram que cerca de $82 \%$ das células presentes na janela (figura 2A) co-expressam as moléculas CD11c e CD11b. Por outro lado, não foram detectadas quantidades significativas de células expressando as moléculas CD4, CD8 ou B220 (figuras 2 D, E e F). As análises realizadas utilizando-se controle isotípico demonstraram que as células dendríticas possuem algum grau de autofluorescência (figura 2 B) porém, este fato não interferiu na análise das subpopulações.

Os resultados obtidos demonstram que o protocolo utilizado é capaz de gerar células com características fenotípica compatíveis com as de células dendríticas. Nossos resultados mostram também que as células obtidas se caracterizam pela expressão das moléculas CD11c e CD11b. 
A

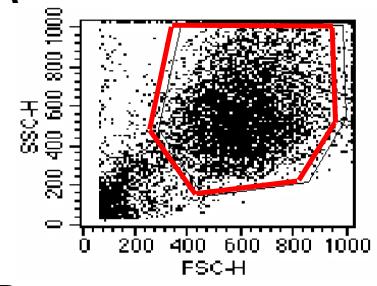

B

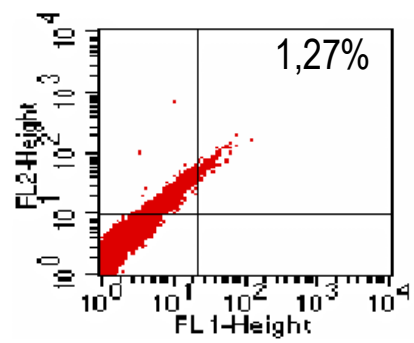

C

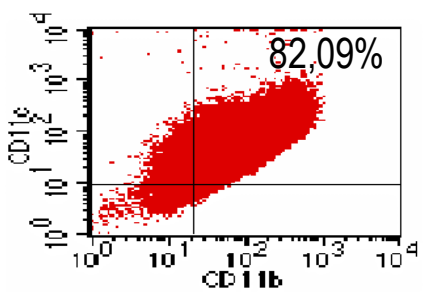

E

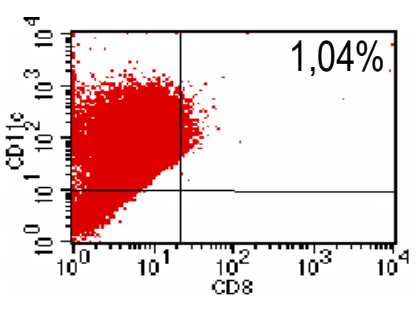

D

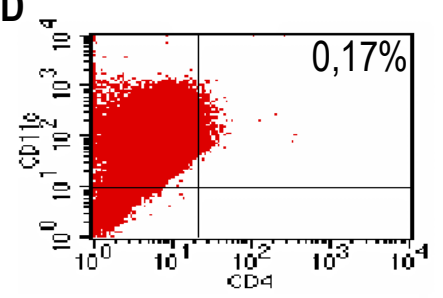

$\mathbf{F}$

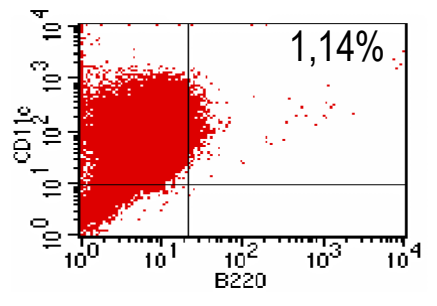

Figura 2. Caracterização fenotípica das células dendríticas derivadas de células de medula óssea. (A) Padrão de granulosidade (SSC) $x$ tamanho (FSC) das células dendríticas obtidas após 7 dias de cultura. A janela em vermelho delimita a população de células dendríticas.(B) Dot plot representando a fluorescência das células dendríticas após incubação com anticorpo isótipo controle. (C-F) Análise das subpopulações de células dendríticas presentes na cultura. As porcentagens indicam células positivas para os dois marcadores analisados. Foram analisadas as células contidas na janela definida em (A). Dados representativos de 4 experimentos realizados. 


\subsection{Estado de ativação das células dendríticas}

As células dendríticas podem ser encontradas em dois estados de ativação: imaturas e maduras. As imaturas caracterizam-se pela baixa expressão de moléculas do complexo de histocompatibilidade principal de classe II (MHCII), moléculas co-estimuladoras, como CD80, CD86, e CD40. Quando as DCs são ativadas, observa-se o aumento da expressão destas moléculas (Banchereau et al, 2000). Funcionalmente, vários trabalhos têm demonstrado que enquanto as DCs maduras são as melhores células apresentadoras de antígeno conhecidas, capazes de induzir a geração de resposta imune adaptativa, as DCs imaturas são capazes de gerar tolerância quando apresentam antígenos (Steinman et al, 2003).

Para determinarmos o estado de ativação das DCs geradas e após tratamento com LPS, a expressão das moléculas de MHC II, CD80, CD86 e CD40 foi analisada por citometria de fluxo. Estas moléculas são importantes para que haja a ativação de linfócitos T pelas DCs, e o aumento de sua expressão está associado à ativação das últimas.

A figura 3 demonstra que as DCs derivadas da medula óssea apresentam fenótipo de células imaturas, expressando baixas quantidades de MHC II, CD80, CD86 e CD40. Por outro lado, após estímulo com $1 \mu \mathrm{g} / \mathrm{mL}$ de LPS por 24 horas as DCs apresentam um aumento na expressão destas moléculas, passando a apresentar um fenótipo de célula ativada.

Podemos assim, concluir que o protocolo utilizado para geração de DCs nos permite obter células dendríticas imaturas. Demonstra-se também que as DCs obtidas são susceptíveis à ativação, uma vez que o estímulo com LPS foi capaz de modificar seu fenótipo para o de DCs maduras. 

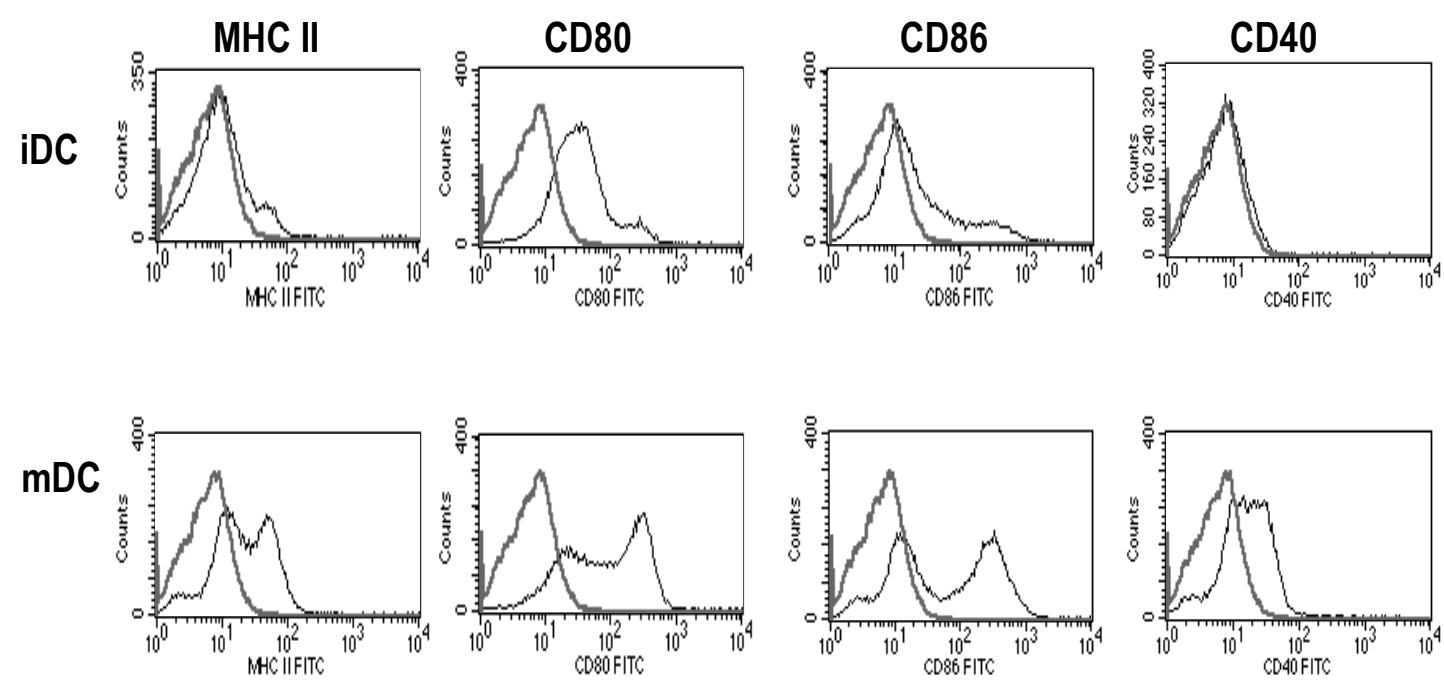

Figura 3. Verificação do estado de ativação das células dendríticas obtidas. Células dendríticas obtidas após 7 dias de cultura foram analisadas por citometria de fluxo para determinação da expressão dos marcadores de ativação MHC II, CD80, CD86 e CD40. Foram avaliadas células dendríticas imaturas (iDC) e células dendríticas induzidas à maturação pela estimulação durante 24 horas com $1 \mu \mathrm{g} / \mathrm{ml}$ de LPS (mDC). Dados representativos de 4 experimentos realizados. Controle isotípico (- ), amostras (-). 


\subsection{Caracterização funcional das células dendríticas}

Havendo caracterizado as DCs obtidas quanto à subpopulação e ao estado de ativação, nosso próximo passo foi a caracterização funcional destas células. Para isso, realizamos um ensaio de cultura leucocitária mista para avaliar a capacidade das células dendríticas em induzir proliferação de células esplênicas alogênicas. Dessa forma, cultivamos as DCs, ativadas ou não com LPS, com esplenócitos alogênicos e avaliamos a proliferação dessas células em diferentes tempos. Este protocolo foi descrito por Steinman e Witmer (1978), numa das primeiras descrições da capacidade ímpar das DCs como células apresentadoras de antígenos.

A figura 4 demonstra que as DCs obtidas são capazes de estimular a proliferação de esplenócitos alogênicos tanto na proporção 1:5 quanto na proporção 1:10 (DC:esplenócitos alogênicos). Além disso, é importante notar que o maior grau de proliferação foi observado entre 72 e 96 horas, enquanto em experimentos nos quais esplenócitos totais foram utilizados como células estimuladoras o pico de proliferação foi observado em 120 horas (dados não mostrados).

Estes dados somam-se aos dados obtidos em relação ao fenótipo para demonstrar que a população celular obtida é constituída essencialmente de células dendríticas. Outra informação importante que podemos depreender destes experimentos é de que a atividade estimuladora das DCs é dependente de seu estado de ativação, isto é, DCs ativadas por LPS induzem resposta proliferativa de forma mais eficiente quando comparadas às DCs não estimuladas. Estes dados estão de acordo com os dados fenotípicos que demonstram uma maior expressão de moléculas de MHC de classe II e moléculas co-estimuladoras nas DCs previamente ativadas com LPS, associando assim os dados fenotípicos relativos à ativação das DCs a uma contrapartida funcional. 


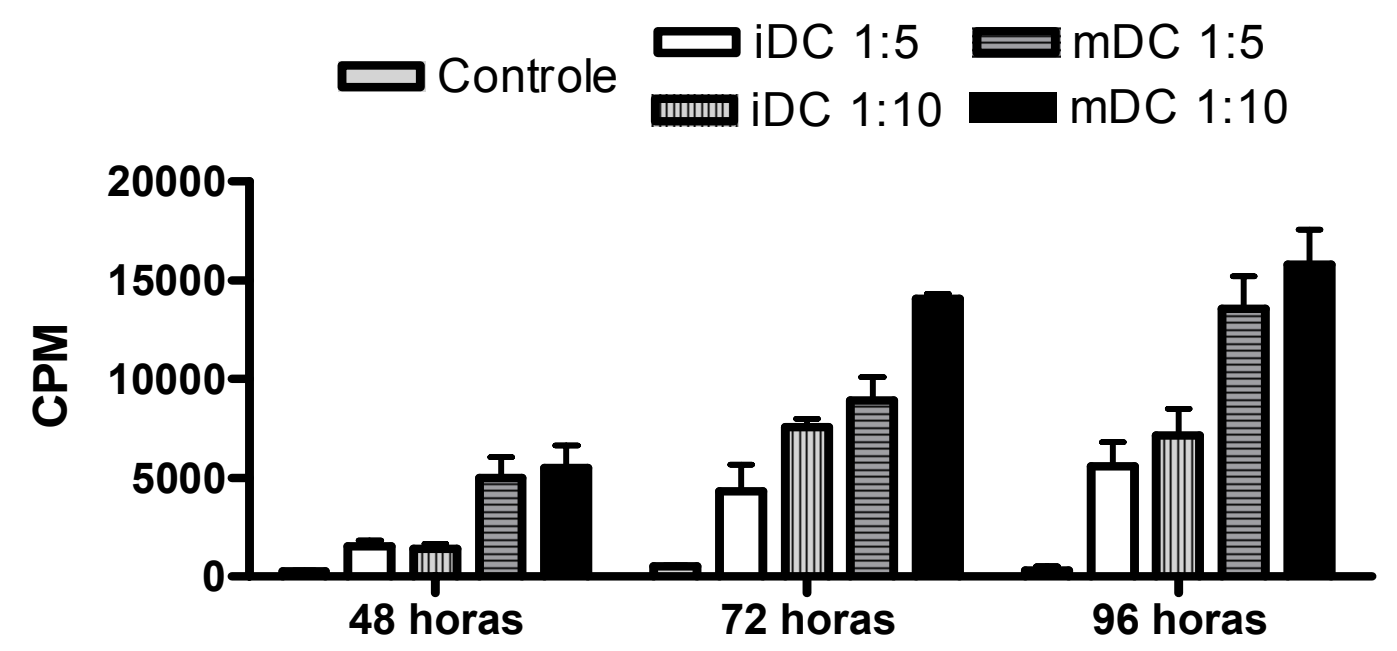

Figura 4. Ensaio de cultura leucocitária mista utilizando células dendríticas como células estimuladoras. Células dendríticas derivadas da medula óssea de camundongos BALB/c estimuladas (mDC) ou não (iDC) previamente com LPS foram co-cultivadas com $5 \times 10^{5}$ células esplênicas de camundongos C57BI/6, nas proporções 1:5 e 1: 10 (DC: célula respondedora). Como controle negativo esplenócitos de camundongos C57BI/6 foram cultivados na ausência de DCs. As células foram incubadas com ${ }^{3} \mathrm{H}$-timidina pelas últimas 18 horas de cultura e a proliferação foi avaliada em contador beta. Dados representativos de 3 experimentos realizados. 


\subsection{Avaliação da apoptose em timócitos}

Para determinarmos os efeitos de antígenos exógenos nas alterações ocorridas na população de células Treg, após o co-cultivo de células de linfonodo com DCs, utilizamos células alogênicas em apoptose. Para isso, buscamos um órgão em que as populações celulares pudessem ser estimuladas a entrar em apoptose através da utilização de um protocolo experimentalmente exeqüível em nosso laboratório. O órgão escolhido foi o timo, e utilizamos o protocolo de indução de apoptose em timócitos por estímulo com dexametasona.

Os timócitos foram incubados com dexametasona por 4 horas. Após esse período foram realizados ensaios de citometria de fluxo para determinar a porcentagem de células em apoptose (Anexina- $\left.\mathrm{V}^{+} \mathrm{PI}^{-}\right)$. Conforme demonstrado na figura 5A, 4 horas após o estímulo com $10^{-7} \mathrm{M}$ de dexametasona cerca de $40 \%$ dos timócitos se encontram em processo de apoptose.

Para determinarmos se 4 horas de estímulo com dexametasona eram suficientes para comprometer toda a população de timócitos com a morte celular por apoptose as células foram lavadas e colocadas novamente em cultura, na ausência de dexametasona, por 2 (figura 5B) ou 4 horas (figura $5 \mathrm{C}$ ) adicionais. Os resultados obtidos demonstram que a presença da dexametasona nas primeiras 4 horas de cultura foi suficiente para que toda a população de timócitos recebesse o estímulo apoptótico e iniciasse o processo de morte celular programada. Mesmo após a lavagem das células e a troca do meio de cultura por meio sem dexametasona, o processo de morte por apoptose não foi interrompido.

Para obtermos maiores evidências de que a morte estava realmente ocorrendo por apoptose realizamos o ensaio de HFS. Esse ensaio determina o grau de fragmentação do DNA, uma característica da morte celular por apoptose. Conforme demonstrado nas figuras 5 A, B e C (linha inferior) houve um aumento de fragmentação de DNA com o passar do tempo. Este aumento é uma medida indireta da atividade de caspases e demonstra que estas enzimas estão ativas, sendo este um dos principais mecanismos efetores associados 
com a morte por apoptose. A diferença entre a porcentagem de células Anexina-V-FITC ${ }^{+} \mathrm{PI}^{-}$ e células com o DNA fragmentado se deve ao fato da fragmentação do DNA ser um evento que possui uma cinética mais lenta do que a exposição de fosfatidilserina na superfície celular durante o processo de apoptose.

Sendo assim, temos que após 4 horas de estímulo com dexametasona, uma porcentagem dos timócitos (cerca de $40 \%$ ) já está em processo de apoptose. Oito horas após o início do estímulo, (4 horas na presença de dexametasona e 4 horas na ausência da mesma) a maior parte dos timócitos (cerca de 65\%) encontra-se em processo de apoptose e uma fração (cerca de 29\%) encontra-se em processo de necrose secundária. Sendo assim, utilizando o protocolo de estimulação dos timócitos com $10^{-7} \mathrm{M}$ de dexametasona por 4 horas garantimos que toda a população de timócitos recebeu o estímulo apoptótico antes de entrar em contato com as DCs e, portanto, garantimos também que estes timócitos não estarão viáveis após as dezoito horas de co-cultura. Dessa forma, estabeleceu-se que após 4 horas de estímulo com dexametasona os timócitos seriam lavados abundantemente com meio de cultura e, subseqüentemente, incubados com as DCs por 18 horas. 
A
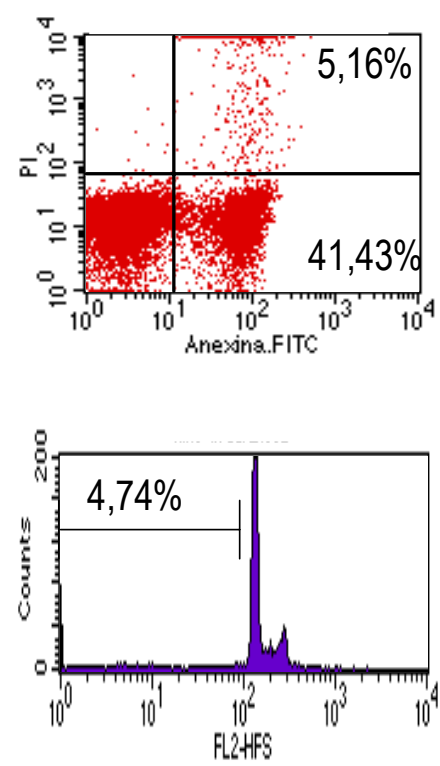

B
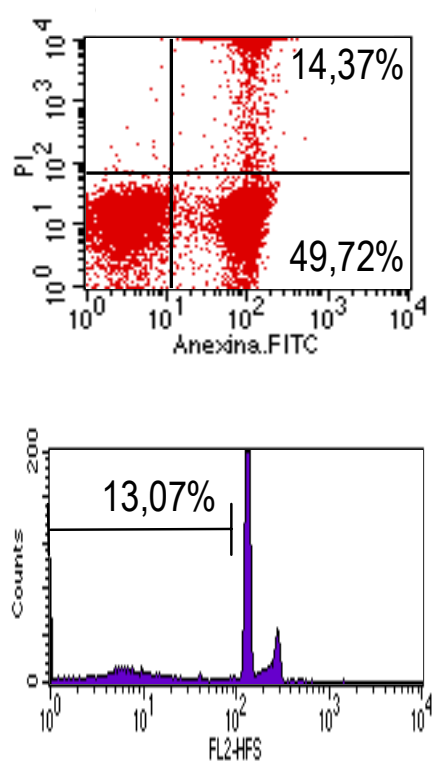

C
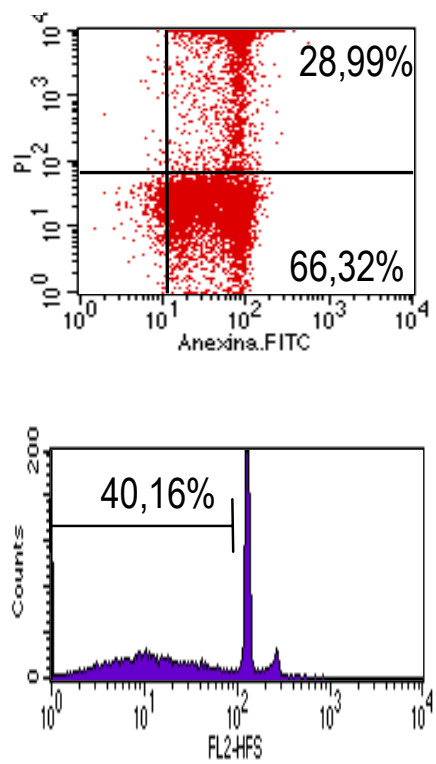

Figura 5. Avaliação da apoptose em timócitos após estimulo com dexametasona. Timócitos foram estimulados por 4 horas com 10-7M de dexametasona. (A) Porcentagem de células em apoptose ou necrose após 4 horas de incubação com dexametasona (linha superior). Porcentagem de núcleos com DNA fragmentado após 4 horas de incubação com dexametasona (linha inferior). (B-C) Porcentagem de células em apoptose ou necrose após 4 horas de incubação com dexametasona seguidas de 2 (B) e 4 (C) horas de incubação na ausência de dexametasona (linha superior). Porcentagem de núcleos com DNA fragmentado após as mesmas condições experimentais (linha inferior). Foram consideradas células apoptóticas células Anexina-V-FITC+PF- (linha superior). Foram considerados eventos apoptóticos os núcleos hipodiplóides, que no gráfico aparecem à esquerda do pico G0-G1 (linha inferior).Dados representativos de 4 experimentos. 


\subsection{Avaliação do estado de ativação das células dendríticas co-cultivadas com timócitos alogênicos em apoptose}

Uma questão a ser analisada em nosso modelo experimental se refere à capacidade das células alogênicas em apoptose alterarem o estado de ativação das DCs durante a cocultura. Para verificarmos se esse era o caso, realizamos análises de citometria de fluxo. Foram analisados marcadores de ativação nas DCs maduras e imaturas incubadas ou não por dezoito horas com timócitos alogênicos em apoptose na proporção 1:5 (DC: célula alogênica em apoptose).

Nossos resultados demonstram que após o co-cultivo com as células alogênicas em apoptose não há alterações importantes no estado de ativação das células dendríticas (figura 6). A única alteração observada é a diminuição da expressão de MHC II quando as DCs maduras são incubadas com as células alogênicas em apoptose. Neste caso, a expressão de MHC II encontra-se diminuída e assemelha-se à expressão observada em DCs imaturas. No entanto, este é o único marcador de ativação que se altera, demonstrando que não há uma modulação importante do estado de ativação das DCs quando estas são incubadas com células alogênicas em apoptose. Aos dados fenotípicos obtidos, associamse os dados com relação à produção de citocinas pelas DCs (figura 8). Estes últimos demonstram que a incubação de células dendríticas com células alogênicas em apoptose não é capaz de modificar o padrão de citocinas produzido por estas células tanto no seu estado imaturo quanto em seu estado maduro (resultados discutidos com maiores detalhes no decorrer do texto). Tomados em conjunto, nossos resultados demonstram que a cocultura com timócitos alogênicos em apoptose não é capaz de alterar o estado de ativação nem das DCs imaturas nem das DCs maduras. 
MHC II
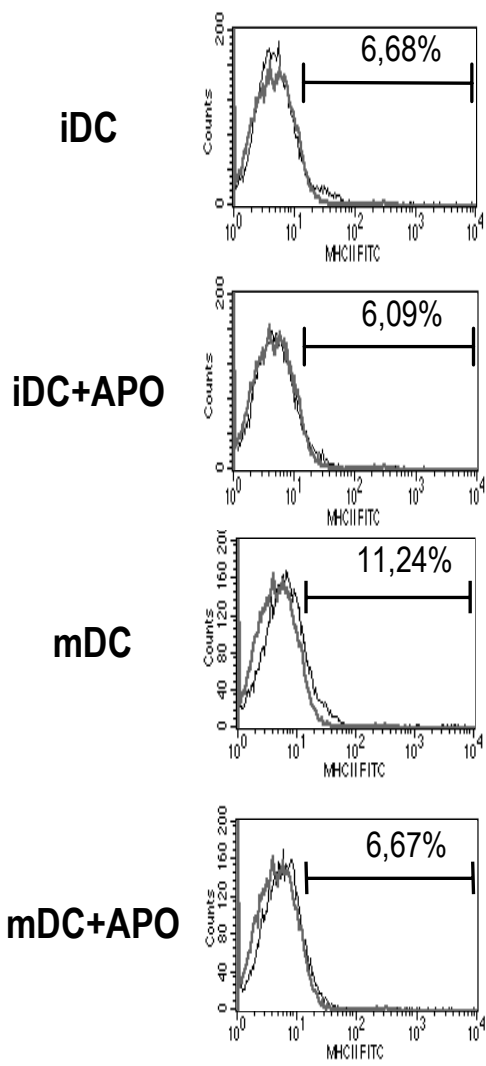

CD80
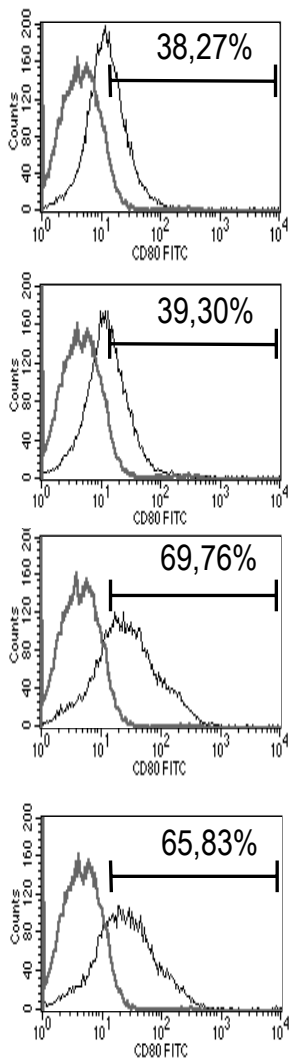

CD86
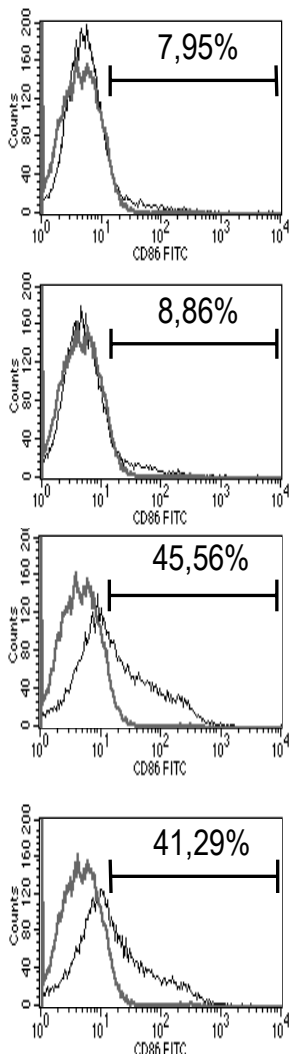

CD40
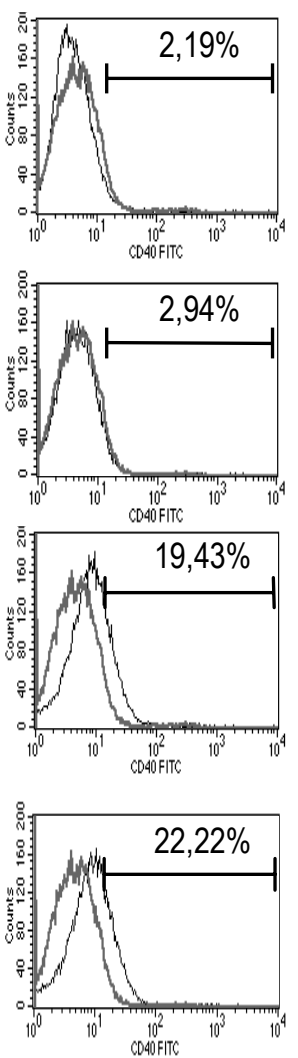

Figura 6. Análise do estado de ativação das células dendríticas após co-cultivo com timócitos alogênicos em apoptose. Células dendríticas obtidas após 7 dias de cultura foram incubadas (na proproção 1:5 DC:célula alogênica em apoptose) durante 18 horas com timócitos alogênicos em apoptose e analisadas por citometria de fluxo para determinação da expressão dos marcadores de ativação MHC II, CD80, CD86 e CD40. Foram analisadas células dendríticas imaturas (iDC), células dendríticas imaturas co-cultivadas com células alogênicas em apoptose (iDC+APO), células dendríticas maduras (estimuladas com $1 \mu \mathrm{g} / \mathrm{mL}$ de LPS) $(\mathrm{mDC})$ e células dendríticas maduras (estimuladas com $1 \mu \mathrm{g} / \mathrm{mL}$ de LPS) e co-cultivadas com células alogênicas em apoptose (mDC+APO). Dados representativos de 3 experimentos realizados. Controle isotípico (-), amostras (-). 


\subsection{Verificação da fagocitose de células alogênicas em apoptose por células} dendríticas

Nosso próximo passo foi verificar se as células dendríticas maduras e imaturas eram capazes de fagocitar células alogênicas em apoptose. Para isso, co-cultivamos células dendríticas maduras e imaturas com diferentes quantidades de células alogênicas em apoptose por 2 e 4 horas. Após estes períodos as DCs foram submetidas a citocentrifugação, as lâminas obtidas foram coradas e realizou-se a contagem das DCs que fagocitaram células alogênicas em apoptose.

A figura 7A mostra uma célula dendrítica que não foi co-cultivada com células alogênicas em apoptose (esquerda) e uma célula dendrítica que fagocitou uma célula alogênica em apoptose (direita). Nossos resultados demonstram que na proporção 1:5 (DC: células alogênicas em apoptose), após 2 horas de co-cultura, um maior número de DCs imaturas havia fagocitado células em apoptose em relação às DCs maduras. Nas outras proporções, 1:1 e 1:10 (DC: células alogênicas em apoptose), essa diferença não foi observada (figura 7B). Por outro lado, a análise da fagocitose após 4 horas demonstrou que um número maior de DCs maduras fagocitaram células alogênicas em apoptose quando co-cultivadas nas proporções 1:1 e 1:10 (figura 7C). No entanto, quando analisamos estes dados em conjunto, ou seja, quando o número de DCs que fagocitaram células alogênicas em apoptose após 2 e 4 horas são considerados conjuntamente, nenhuma diferença entre as DCs imaturas e maduras foi observada (figura 7D).

Estes resultados sugerem uma diferença na cinética de fagocitose de células alogênicas em apoptose entre DCs maduras e imaturas, isto é, as DCs imaturas são capazes de fagocitar um maior número de células em apoptose em um período de tempo menor (2 horas) enquanto as DCs maduras fagocitam as células em apoptose mais tardiamente (4 horas). No entanto, com relação ao número final de DCs que fagocitaram células alogênicas em apoptose (2 e 4 horas analisadas conjuntamente) não foi observada diferença entre as DCs nos diferentes estados de ativação. Sendo assim, podemos dizer que apesar das 
diferenças observadas nos tempos analisados, a quantidade final de DCs que fagocitaram células alogênicas em apoptose é semelhante nos dois estados de ativação. 
A
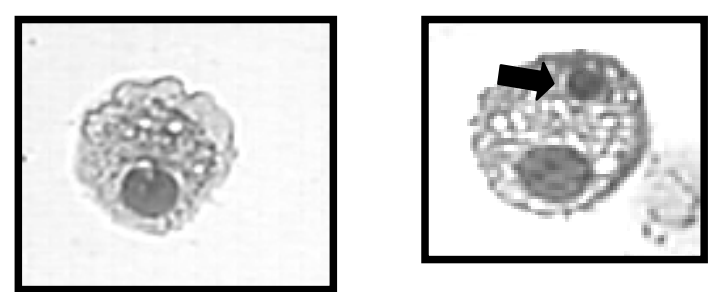

B

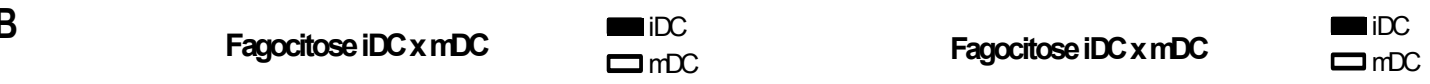

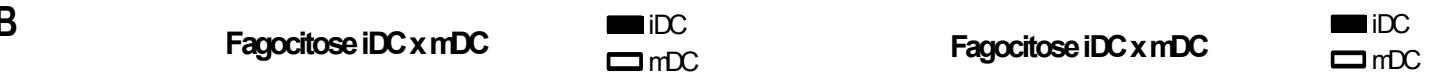

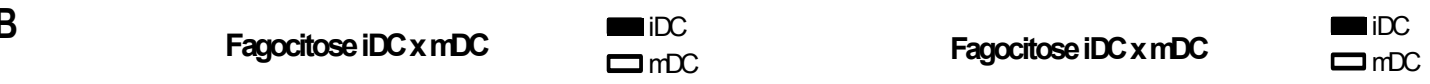
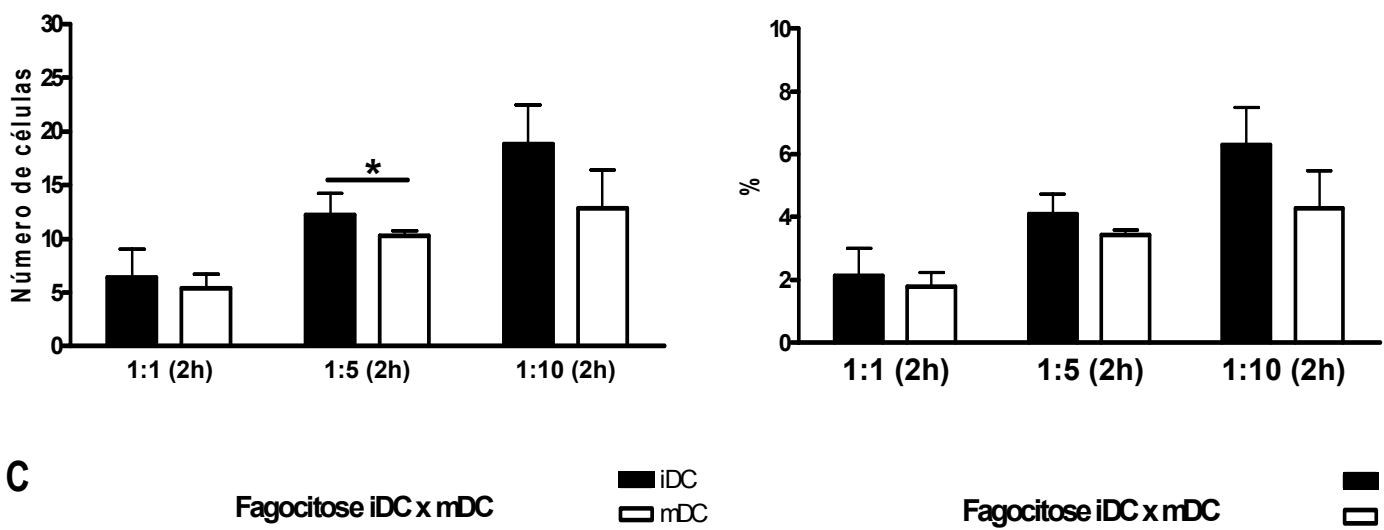

Fagocitose iDC x mDC
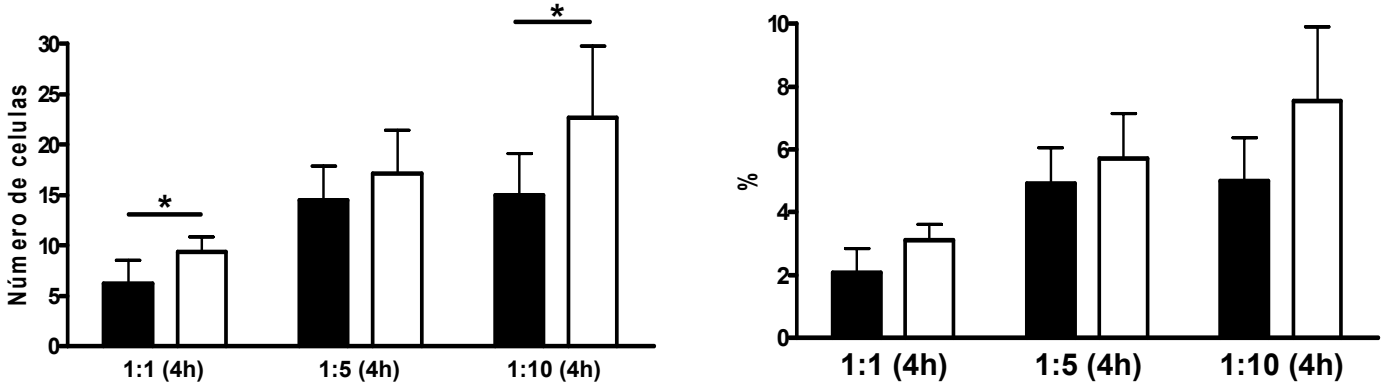

D
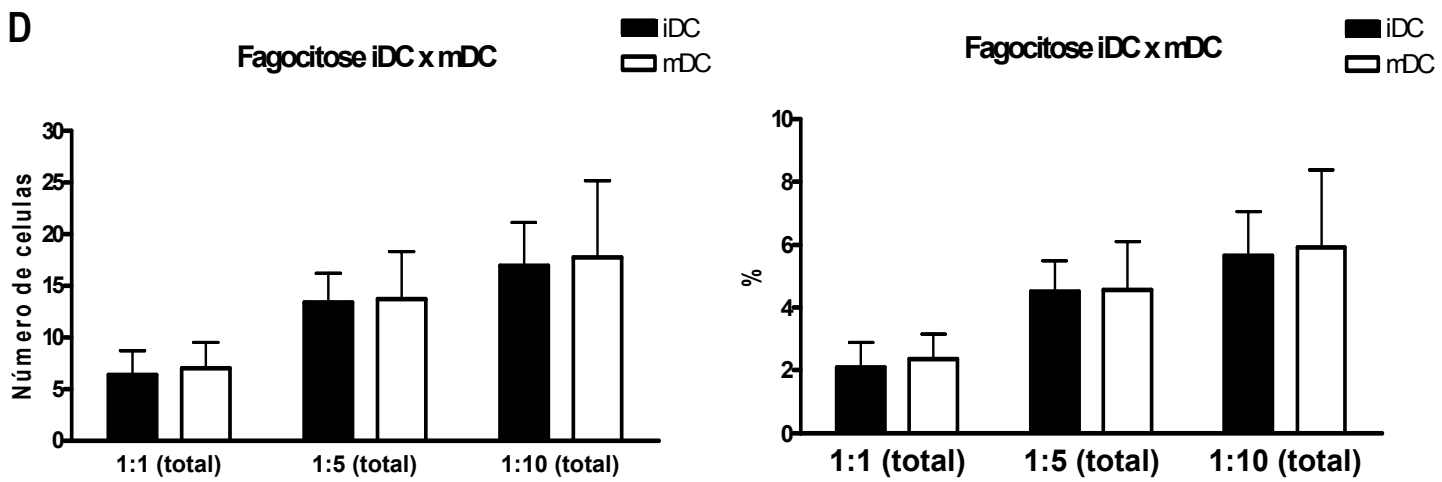

Figura 7. Avaliação da fagocitose de timócitos alogênicos em apoptose por células dendríticas maduras (mDC) e imaturas (iDC). $4 \times 10^{4}$ células dendríticas foram incubadas com diferentes quantidades de timócitos alogênicos em apoptose determinando as proporções 1:1, 1:5 e 1:10 (DC: célula alogênica em apoptose). Após 2 e 4 horas de co-culturas as células dendríticas foram submetidas a citocentrifugação, as lâminas obtidas foram coradas e o grau de fagocitose determinado por microscopia.(A) Célula dendrítica (esquerda). Timócito em apoptose (seta) fagocitado por célula dendrítica (direita). Aumento de 40x. (B-C) Quantidade (esquerda) e porcentagem (direita) de células dendríticas que fagocitaram timócitos em apoptose após 2 (B) e 4 (C) horas de co-cultura. (D) Quantidade (esquerda) e porcentagem (direita) de células dendríticas que fagocitaram timócitos em apoptose analisando-se os resultados obtidos após 2 e 4 horas de co-cultura em conjunto (total). Para determinação do número e porcentagem de DCs que havia fagocitado células em apoptose foram analisadas 300 DCs por lâmina. * $p<0,05$ (Teste Mann-Whitney). 


\subsection{Análise da produção de citocinas pelas DCs em diferentes condições} experimentais

Um dos fatores preponderantes no desenvolvimento da resposta imune é o microambiente em que ela se inicia. Especialmente no desenvolvimento de uma resposta imune adaptativa, o microambiente é capaz de influenciar decisivamente a maneira como os linfócitos $\mathrm{T}$ ativados irão se comportar frente ao antígeno. Um exemplo da influência do microambiente no desenvolvimento da resposta imune adaptativa pode ser observado em trabalhos recentes demonstrando que diferentes citocinas, presentes no momento da apresentação de antígeno, podem induzir a geração de subtipos de linfócitos $T$ capazes de respostas efetoras distintas (Bettelli et al, 2006; Harrington et al, 2006). Sabendo-se da importância deste fato, investigamos a produção de algumas citocinas pelas DCs obtidas. Realizamos a análise da produção de IL-10, TNF- $\alpha$, IL-12 e TGF- $\beta$ pelas células dendríticas.

A produção de citocinas foi avaliada nas células dendríticas após o estímulo com $1 \mu \mathrm{g} / \mathrm{mL}$ de LPS durante 24 horas ou após a co-cultura das DCs com células alogênicas em apoptose. Alternativamente, a produção de citocinas foi avaliada em células dendríticas estimuladas com $1 \mu \mathrm{g} / \mathrm{mL}$ de LPS por vinte quatro horas às quais foram adicionadas células alogênicas em apoptose.

As análises de IL-10, TNF- $\alpha$ e IL-12p70 demonstram que estas citocinas possuem um padrão de produção muito semelhante. Essas citocinas são secretadas apenas quando as DCs são estimuladas por LPS e a adição de células alogênicas em apoptose não modula esta resposta. A análise da produção de TGF- $\beta$ demonstrou um quadro diferente quando comparado ao padrão de produção das outras citocinas. A produção desta citocina foi detectada em todas as condições experimentais testadas, sendo que o nível de secreção da mesma não foi significativamente alterado em nenhuma delas (figura 8). 

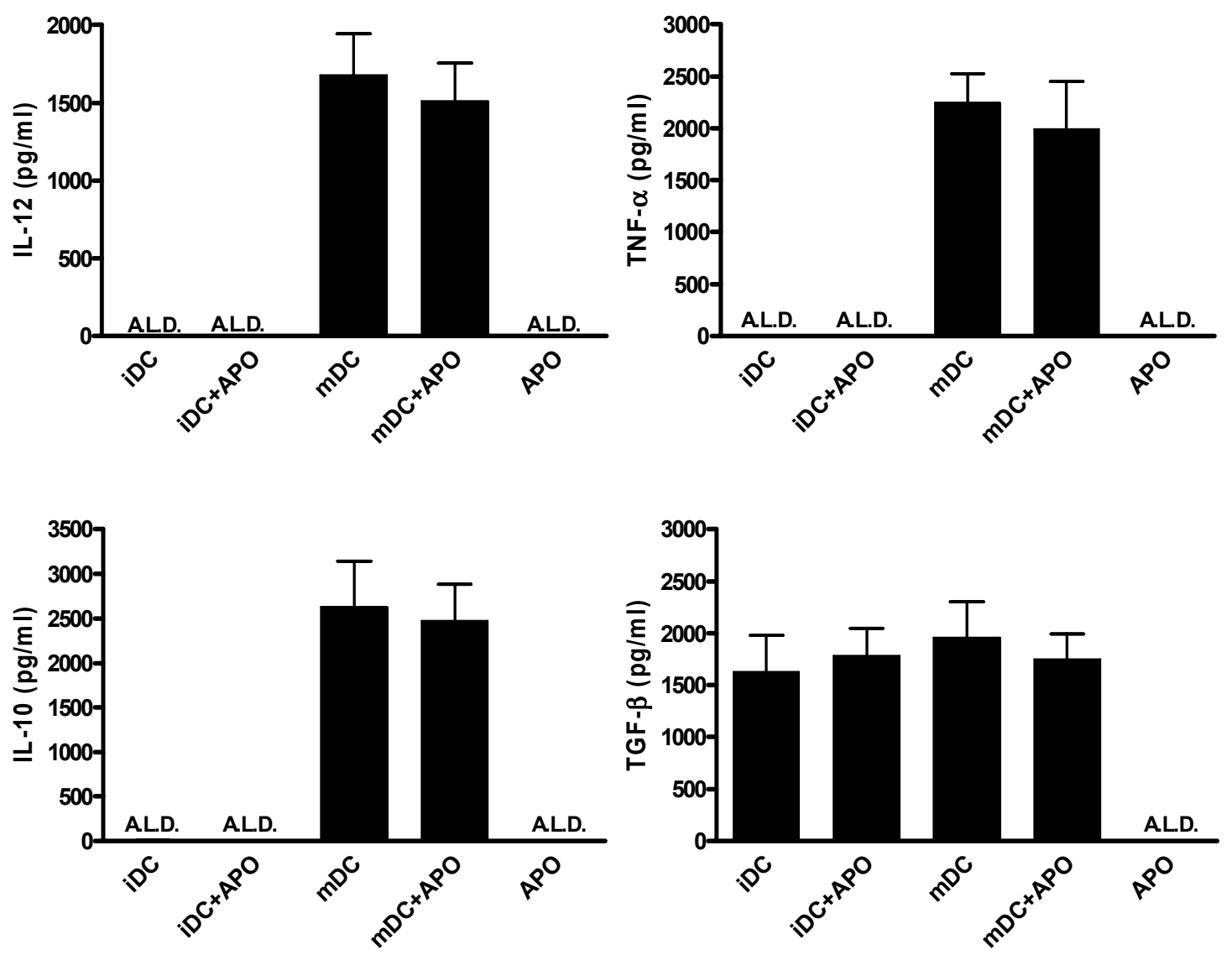

Figura 8. Análise da produção de IL-12p70, TNF-a, IL-10 e TGF- $\beta$. A produção das citocinas foi analisada em células dendríticas imaturas (iDC), células dendríticas imaturas co-cultivadas com células alogênicas em apoptose (iDC+APO), células dendríticas maduras (estimuladas com $1 \mu \mathrm{g} / \mathrm{mL}$ de $L P S)(\mathrm{mDC})$ ou células dendríticas maduras (estimuladas com $1 \mu \mathrm{g} / \mathrm{mL}$ de LPS) e co-cultivadas com células alogênicas em apoptose (mDC+APO). Como controle foi determinada a produção das citocinas pelas células alogênicas em apoptose (APO). Para a determinação da produção das citocinas foram utilizadas amostras de dois experimentos independentes, dosadas em triplicatas. A.L.D. = Abaixo do limite de detecção. 


\subsection{Avaliação da expressão de Foxp3 nas células T CD4}

Tem sido demonstrado que as células T reguladoras, caracterizadas pela expressão de CD $4^{+} C D 25^{+}$Foxp $^{+}$, podem ser expandidas após interações com células dendríticas. Com o intuito de verificarmos qual o comportamento das células Treg em nosso modelo experimental, realizamos análises de citometria de fluxo para detectar esta população celular após a co-cultura de células de linfonodo com DCs nas diferentes condições experimentais. Como único marcador específico para as células Treg é fator de transcrição Foxp3 realizamos a verificação da expressão deste fator de transcrição nas células T $\mathrm{CD} 4^{+} \mathrm{CD} 25^{+}$.

Como demonstrado na figura 9 , a população de células $C D 4^{+} \mathrm{CD} 25^{+}$aumenta em todas as condições experimentais analisadas quando comparada à população presente em linfonodos de animais naïve. No entanto, este aumento é mais pronunciado nas condições em que as DCs estão imaturas, especialmente na presença de aloantígenos.

LN
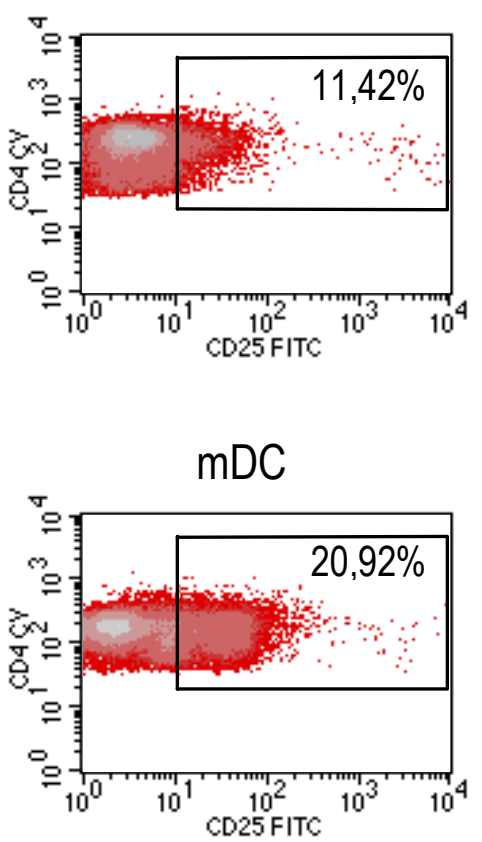

iDC
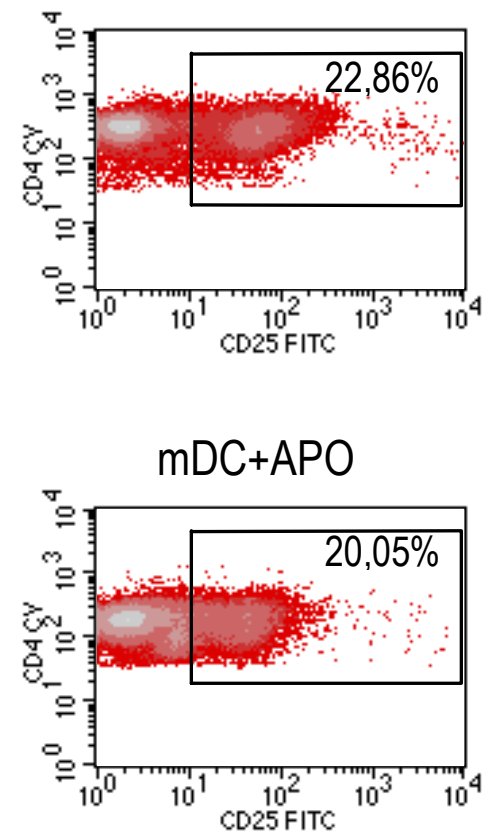

iDC+APO

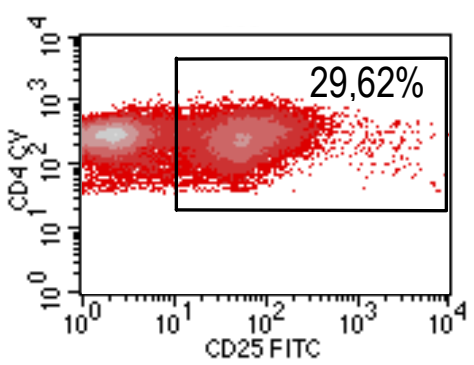

CD25FITC

Figura 9. Porcentagem de células $\mathrm{CD} 4{ }^{+} \mathrm{CD} 25^{+}$obtidas após co-cultura de células de linfonodo com DCs em diferentes condições experimentais. Células de linfonodo (LN), células de linfonodo após co-cultura com DCs imaturas (iDC), células de linfonodo após co-cultura com DCs imaturas incubadas com células alogênicas em apoptose (iDC+APO), células de linfonodo após co-cultura com DCs ativadas por LPS (mDC) ou células de linfonodo após co-cultura com DCs ativadas por LPS e incubadas com células alogênicas em apoptose (mDC+APO). As células de linfonodo foram co-cultivadas por 5 dias com DCs. As porcentagens indicadas se referem à população de células $\mathrm{CD} 4^{+}$. Dados representativos de 4 experimentos. 
Para determinarmos se o aumento na população de células $C D 4^{+} C D 25^{+}$foi decorrente do crescimento da população de células Treg e não da ativação de linfócitos $\mathrm{T}$ naïve, verificamos a expressão de Foxp3 nestas células. Conforme demonstrado na figura 10, a porcentagem de células $C D 4^{+} \mathrm{CD} 25^{+}$Foxp $3^{+}$aumenta em relação à porcentagem encontrada em linfonodos de animais naïve em todas as condições experimentais analisadas, seguindo um padrão semelhante ao observado na análise das células $C D 4^{+} \mathrm{CD} 25^{+}$. Além disso, a porcentagem de células $\mathrm{CD} 4^{+} \mathrm{CD} 25^{+}$Foxp $3^{+}$se mostra muito semelhante à porcentagem de células $\mathrm{CD} 4^{+} \mathrm{CD} 25^{+}$, demonstrando que o aumento encontrado nesta população se deve a um aumento da população de células Treg.

Analisando-se em esses dados em conjunto notamos que a porcentagem de células $\mathrm{CD}^{+}{ }^{+} \mathrm{Foxp}^{+}{ }^{+}$encontra-se aumentada em todas as condições experimentais analisadas quando comparadas à porcentagem verificada em linfonodos de animais naïve. Notamos ainda que este aumento é mais pronunciado nas condições em que as DCs estão imaturas, sendo ligeiramente superior na condição experimental em que há presença do antígeno alogênico (figura 11A). O mesmo perfil é observado quando analisamos as porcentagens de células CD4 ${ }^{+} \mathrm{CD} 25^{+}$Foxp $3^{+}$(figura 11B).

Nossas análises permitiram identificar uma diminuição da população CD $4^{+}$CD25-Foxp $3^{+}$ quando comparada à mesma população observada em linfonodos de animais naïve em três das quatro condições experimentais analisadas. A única condição experimental em que essa diminuição não foi observada foi a condição experimental em que as células de linfonodo foram co-cultivadas com DCs maduras (figura 11C). Quanto à porcentagem de células ativadas, determinadas fenotipicamente como $\mathrm{CD}^{+}{ }^{+} \mathrm{CD} 25^{+}$Foxp3-, não notamos qualquer diferença entre os grupos analisados.

Tomados em conjunto nossos dados sugerem que o aumento observado na população $\mathrm{CD} 4^{+} \mathrm{CD} 25^{+}$se dá às custas do aumento da população de células Treg, caracterizadas pela expressão do fator de transcrição Foxp3. Além disso, este aumento é mais pronunciado quando as DCs encontram-se imaturas e há presença de aloantígeno. Por outro lado, 
notamos uma diminuição da porcentagem de células $\mathrm{CD}^{+}{ }^{+} \mathrm{CD} 25^{-} \mathrm{Foxp}^{+}$em todas exceto uma condição experimental. Quanto às células ativadas, não observamos nenhuma diferença entre os grupos analisados.

LN

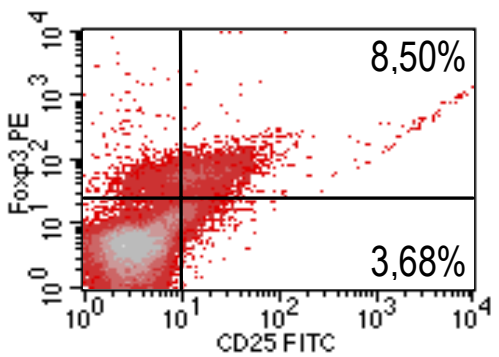

$\mathrm{mDC}$

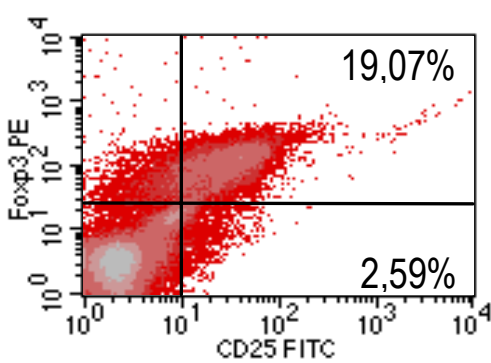

iDC

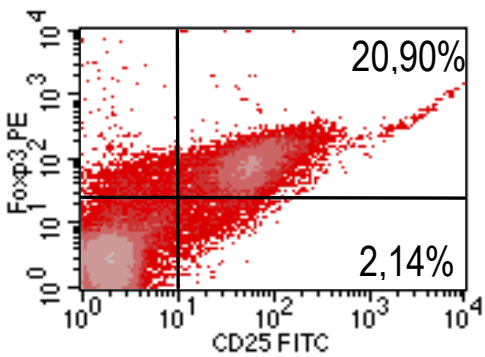

$\mathrm{mDC}+\mathrm{APO}$

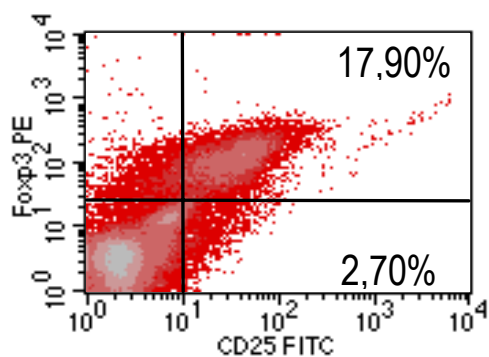

iDC+APO

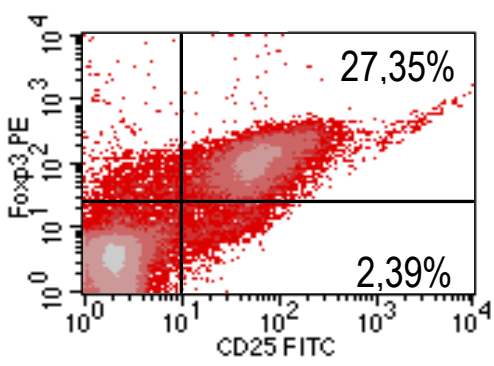

Figura 10. Análise da expressão de Foxp3 nas células $C D 4{ }^{+} C D 25^{+}$. A expressão de Foxp3 foi analisada na população de células $\mathrm{CD} 4^{+} \mathrm{CD} 25^{+}$após co-cultura de células de linfonodo por 5 dias com DCs nas diferentes condições experimentais. Células de linfonodo $(\mathrm{LN})$, células de linfonodo após co-cultura com DCs imaturas (iDC), células de linfonodo após co-cultura com DCs imaturas incubadas com células alogênicas em apoptose (iDC+APO), células de linfonodo após co-cultura com DCs ativadas por LPS ( $\mathrm{mDC}$ ) ou células de linfonodo após co-cultura com DCs ativadas por LPS e incubadas com células alogênicas em apoptose (mDC+APO). As porcentagens indicadas se referem à população de células $\mathrm{CD} 4^{+}$. Dados representativos de 4 experimentos. 
A

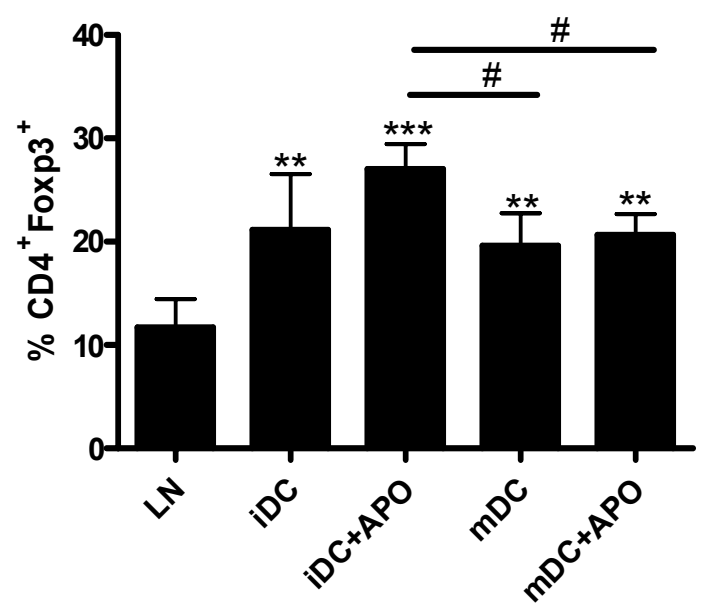

C

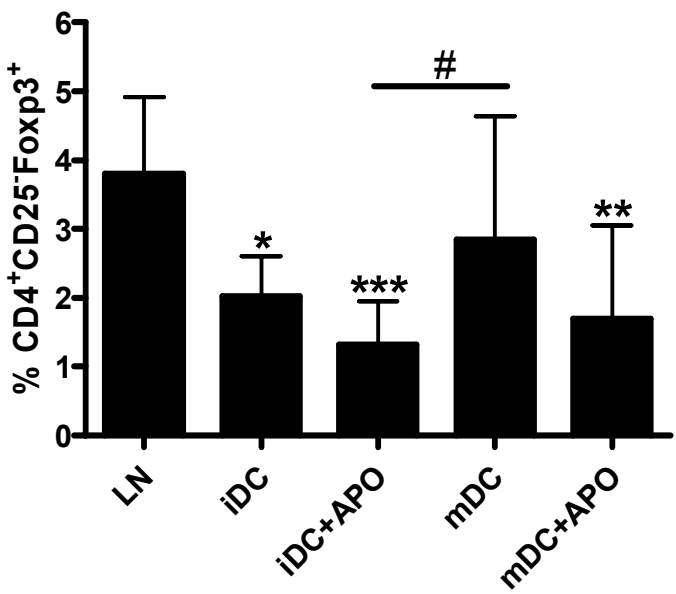

B

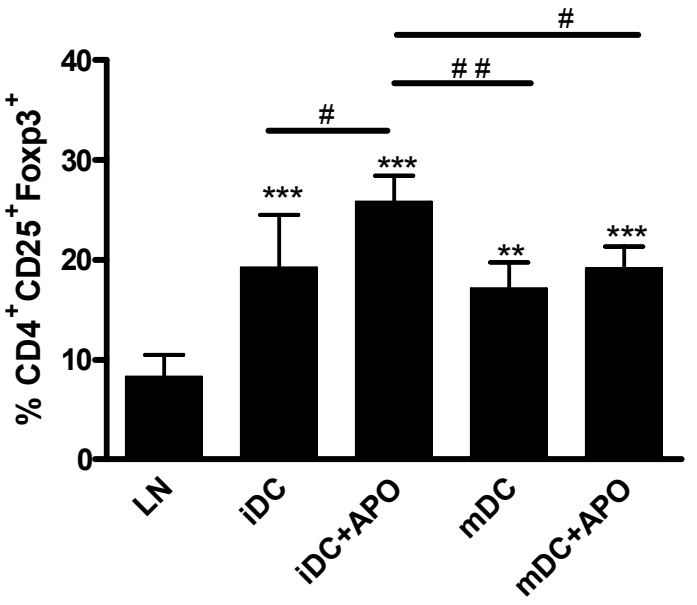

D

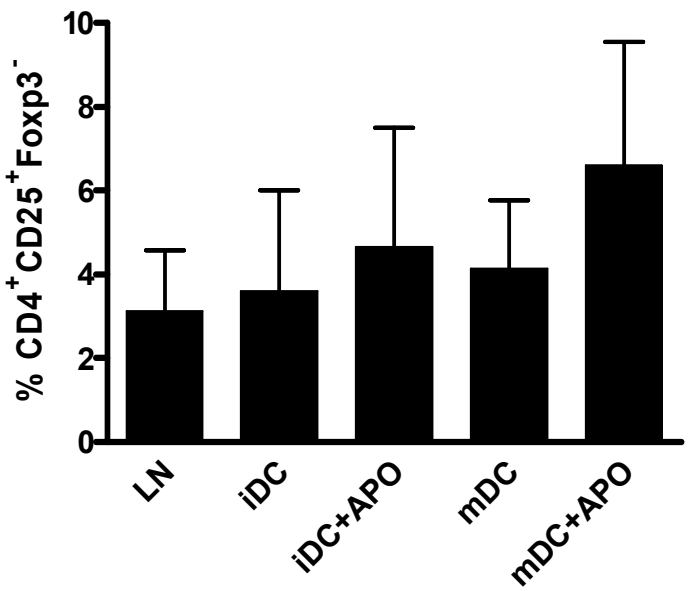

Figura 11. Análise das diferentes populações celulares determinadas por citometria de fluxo. Células de linfonodo foram co-cultivadas por 5 dias com DCs nas diferentes condições experimentais e analisadas por citometria de fluxo. (A) Porcentagem de células $\mathrm{CD}^{+} \mathrm{Foxp}^{+}$(B) Porcentagem de células $\mathrm{CD} 4^{+} \mathrm{CD} 25^{+} \mathrm{Foxp} 3^{+}$(C) Porcentagem de células $\mathrm{CD}^{+}{ }^{+} \mathrm{CD} 25-\mathrm{Foxp}_{3}+$. (D) Porcentagem de células CD4+CD25+Foxp3- Células de linfonodo (LN), células de linfonodo após co-cultura com DCs imaturas (iDC), células de linfonodo após co-cultura com DCs imaturas incubadas com células alogênicas em apoptose (iDC+APO), células de linfonodo após co-cultura com DCs ativadas por LPS ( $\mathrm{mDC}$ ) ou células de linfonodo após co-cultura com DCs ativadas por LPS e incubadas com células alogênicas em apoptose (mDC+APO). As porcentagens indicadas se referem à população de células $\mathrm{CD}^{+}$. Dados representativos de 4 experimentos. ${ }^{* *} p<0,01,{ }^{* *} p<0,001$ (em relação à porcentagem de células obtidas de linfonodo (LN)). \#p<0,05, \#\#p<0,01 (significativo entre os grupos indicados) (Testes ANOVA e Tukey). 


\subsection{Efeito da depleção das células $C D 4^{+} C D 25^{+}$presentes nos linfonodos de animais naïve nas alterações verificadas na população de células $T$ reguladoras}

No nosso modelo experimental uma questão importante a ser considerada consiste em determinar se o aumento na população de células $C D 4^{+} C D 25^{+} F o x p 3^{+}$é fruto da expansão destas células, já presentes no linfonodo, ou se estas células estão se originando a partir da conversão de células $\mathrm{CD} 4^{+} \mathrm{CD} 25^{*}$.

Para analisarmos esta questão utilizamos um protocolo para a separação de células T $\mathrm{CD}^{+} \mathrm{CD} 25^{+}$do linfonodo de camundongos naïve (descrito em Materiais e Métodos), e adicionamos às DCs em diferentes condições experimentais células de linfonodo depletadas de células $\mathrm{T} \mathrm{CD} 4^{+} \mathrm{CD} 25^{+}$. Como demonstrado na figura 12, o protocolo de depleção é muito eficiente e possibilita a obtenção de aproximadamente $98 \%$ de pureza na fração celular depletada de células $\mathrm{CD} 4^{+} \mathrm{CD} 25^{+}$.
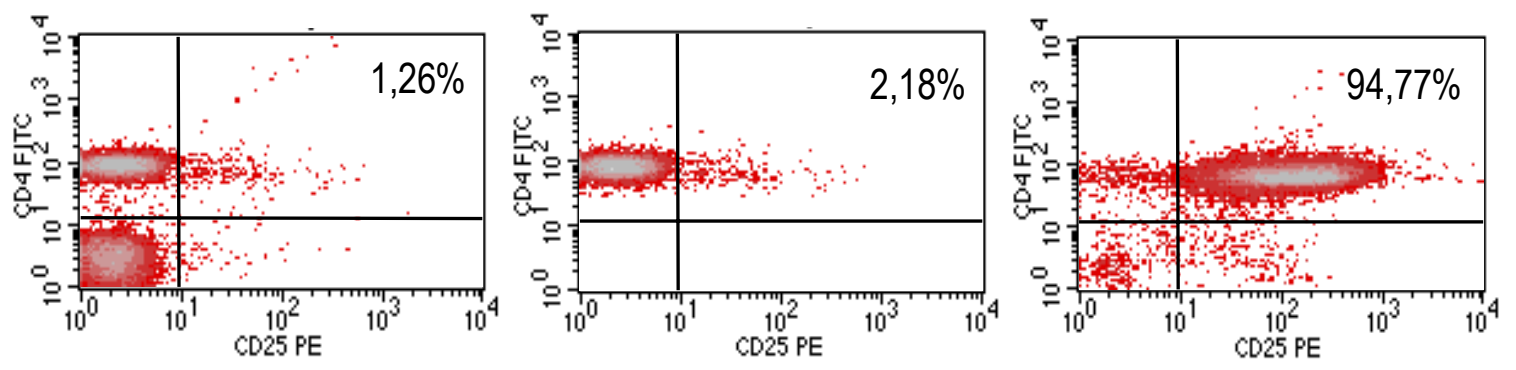

Figura 12. Pureza das frações celulares após depleção das células CD4+CD25+. Após a depleção utilizando "beads" magnéticos as células foram analisadas por citometria de fluxo para determinação da pureza das diferentes frações celulares obtidas. Porcentagem de células $\mathrm{CD} 4{ }^{+} \mathrm{CD} 25^{+}$contaminantes em relação à população total de células obtidas após a depleção (esquerda). Porcentagem de células $C D 4+C D 25^{+}$contaminantes em relação à população de células $\mathrm{CD}^{+}$obtidas após a depleção (centro). Porcentagem de pureza obtida na fração de células CD4+CD25+ (direita).

Tendo obtido uma boa pureza na fração depletada de células $T$ CD $4^{+} C D 25^{+}$, partimos então para a verificação da expressão de CD25 e de Foxp3 na população de linfócitos T $\mathrm{CD}^{+}$após co-cultura com células dendríticas nas diferentes condições experimentais. 
A análise por citometria de fluxo demonstrou que há aumento da população $\operatorname{CD} 4^{+} \mathrm{CD} 25^{+}$ em todas as condições experimentais analisadas porém, este aumento é menor do que o observado nas co-culturas em que as células $C D 4^{+} \mathrm{CD} 25^{+}$estavam presentes inicialmente. Os resultados demonstram também que o aumento é mais pronunciado nas condições de cultura em que há presença do aloantígeno (figura 13).
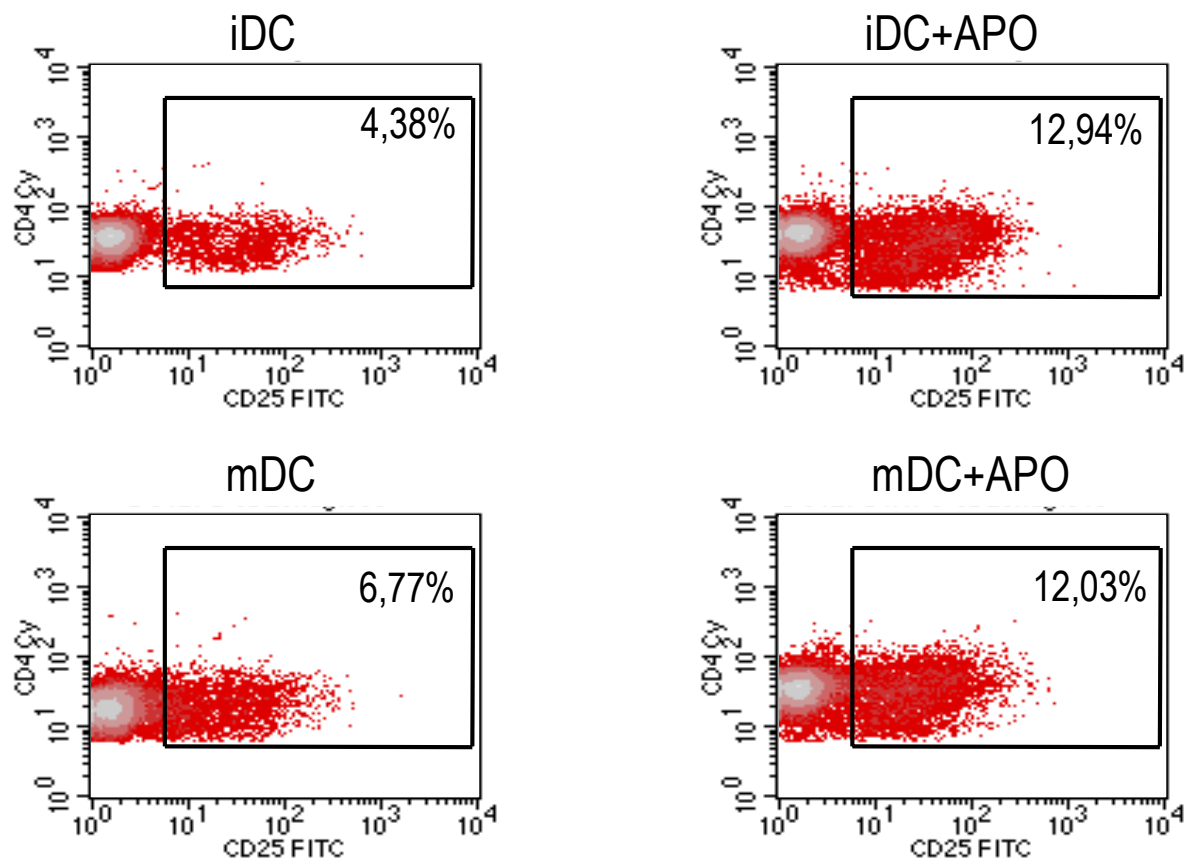

Figura 13. Avaliação da população $\mathrm{CD} 4^{+} \mathrm{CD} 25^{+}$após co-cultivo de células de linfonodo depletadas de células $\mathrm{CD} 4{ }^{+} \mathrm{CD} 25^{+}$com DCs nas diferentes condições experimentais. As células de linfonodo foram co-cultivadas por 5 dias com DCs nas diferentes condições experimentais. Células de linfonodo após co-cultura com DCs imaturas (iDC), células de linfonodo após co-cultura com DCs imaturas incubadas com células alogênicas em apoptose (iDC+APO), células de linfonodo após co-cultura com DCs ativadas por LPS (mDC) ou células de linfonodo após co-cultura com DCs ativadas por LPS e incubadas com células alogênicas em apoptose (mDC+APO)..As porcentagens indicadas se referem à população de células $\mathrm{CD}^{+}$. Dados representativos de 2 experimentos.

O aumento da população $\mathrm{CD} 4^{+} \mathrm{CD} 25^{+}$, no entanto, não nos assegura que a geração de células Treg está ocorrendo, uma vez que este aumento pode indicar a ativação de linfócitos T naïve. Sendo assim, realizamos a análise da expressão do fator de transcrição Foxp3 pelos linfócitos T CD4 ${ }^{+} \mathrm{CD} 25^{+}$(figura 14).

Nossas análises por citometria de fluxo demonstraram que a porcentagem de células $\mathrm{CD}^{+}{ }^{+} \mathrm{Foxp}^{+}$é maior quando as células de linfonodo são co-cultivadas com células 
dendríticas imaturas e há presença de aloantígeno do que nas outras condições experimentais (figura 15A). Por sua vez, a análise da expressão de Foxp3 nas células $\mathrm{CD} 4^{+} \mathrm{CD} 25^{+}$indicou que apenas uma fração destas células expressava este fator de transcrição (figuras 14 e 15B). O restante das células $C D 4^{+} C D 25^{+}$não expressam Foxp3, apresentando um fenótipo característico de linfócitos T ativados (figura 14 e 15D). É importante ressaltar que este aumento na população de células $\mathrm{CD}^{+}{ }^{+} \mathrm{CD} 25^{+}$Foxp3 ${ }^{-}$não é evidenciado quando as células $\mathrm{CD} 4^{+} \mathrm{CD} 25^{+}$não são depletadas antes da co-cultura (figura 10 e 11D). Com relação à população de células $C D 4^{+} C D 25^{-}$Foxp $^{+}$, nota-se que ela está diminuída nas condições em que há presença de antígeno alogênico, tanto em DCs maduras quanto em DCs imaturas, quando comparada à porcentagem observada na condição experimental em que há apenas DCs imaturas (figura 15C).

Os dados obtidos sugerem que as células Treg controlam a expansão de linfócitos $T$ ativados $\left(\mathrm{CD}^{+} \mathrm{CD} 25^{+} \mathrm{Foxp}^{-}\right)$frente aos antígenos alogênicos. Notamos ainda que as porcentagens de células $\mathrm{CD}^{+} \mathrm{CD} 25^{+} \mathrm{Foxp} 3^{+}$obtidas são menores nestas condições experimentais quando comparadas às obtidas nas condições em que as células $C D 4^{+} \mathrm{CD} 25^{+}$ estavam presentes desde o início da co-cultura. 

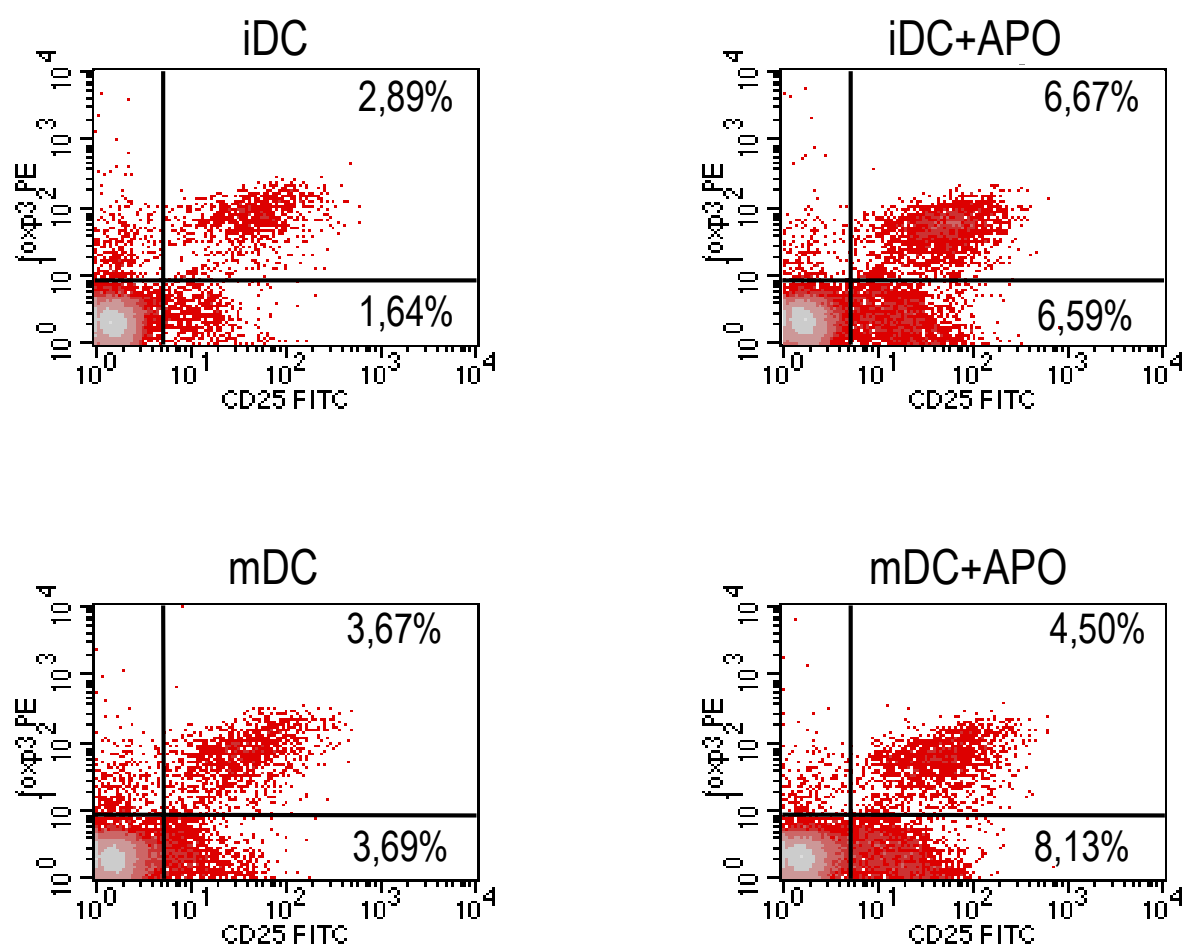

Figura 14. Avaliação da população $C D 4+C D 25+F o x p 3^{+}$após co-cultivo de células de linfonodo depletadas de células $\mathrm{CD} 4^{+} \mathrm{CD} 25^{+}$com células dendríticas. As células de linfonodo depletadas de células $\mathrm{CD} 4^{+} \mathrm{CD} 25^{+}$foram cocultivadas por 5 dias com DCs nas diferentes condições experimentais. Células de linfonodo após co-cultura com DCs imaturas (iDC), células de linfonodo após co-cultura com DCs imaturas incubadas com células alogênicas em apoptose (iDC+APO), células de linfonodo após co-cultura com DCs ativadas por LPS (mDC) ou células de linfonodo após co-cultura com DCs ativadas por LPS e incubadas com células alogênicas em apoptose (mDC+APO). As porcentagens indicadas se referem à população de células CD4+. Dados representativos de 2 experimentos. 
A
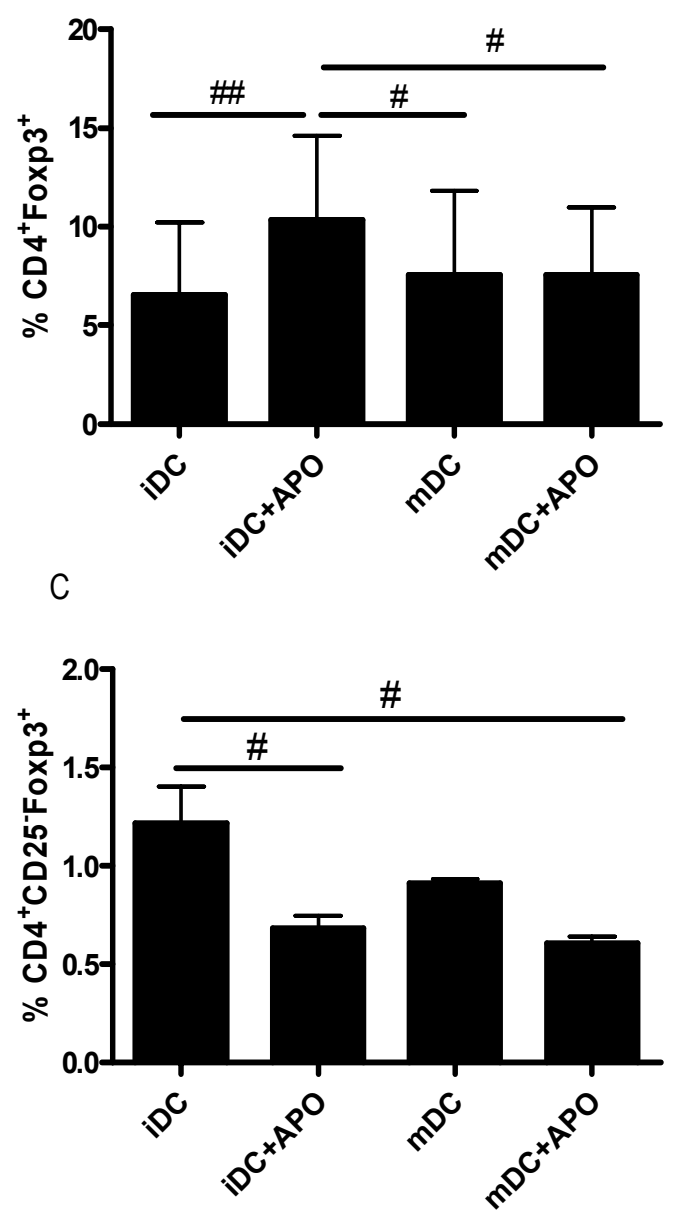

B

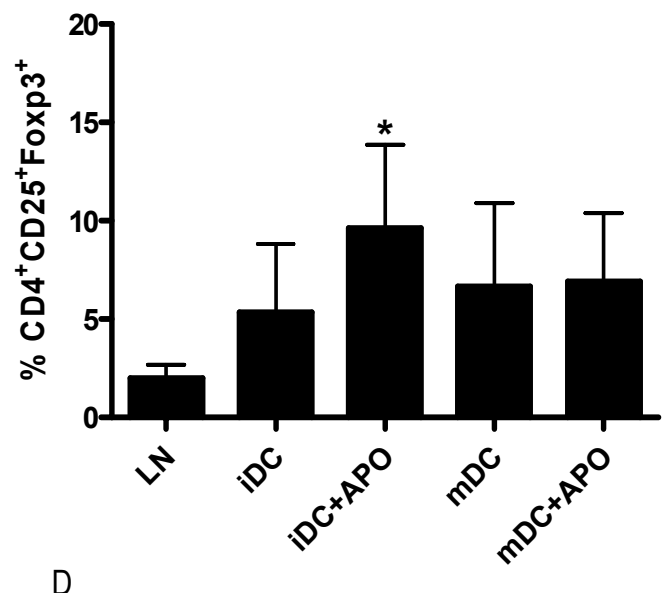

D

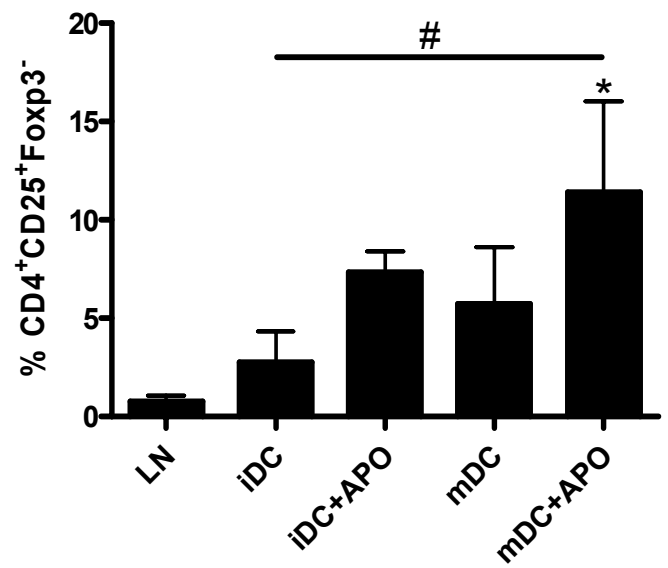

Figura 15. Análise das diferentes populações celulares determinadas por citometria de fluxo após co-cultivo de células de linfonodo depletadas de células $\mathrm{CD} 4^{+} \mathrm{CD} 25^{+}$com células dendríticas. Células de linfonodo depletadas de células $\mathrm{CD} 4^{+} \mathrm{CD} 25^{+}$foram co-cultivadas por 5 dias com DCs nas diferentes condições experimentais. . (A) Porcentagem de células $\mathrm{CD} 4^{+}{ }^{+} \mathrm{Oxp}^{+}{ }^{+}$(B) Porcentagem de células $\mathrm{CD}^{+} \mathrm{CD}^{2} 5^{+} \mathrm{Foxp}^{+}$(C) Porcentagem de células $\mathrm{CD} 4^{+} \mathrm{CD} 25-\mathrm{Foxp} 3^{+}$. (D) Porcentagem de células CD4+CD25+Foxp3-. Células de linfonodo após co-cultura com DCs imaturas (iDC), células de linfonodo após co-cultura com DCs imaturas incubadas com células alogênicas em apoptose (iDC+APO), células de linfonodo após co-cultura com DCs ativadas por LPS (mDC) ou células de linfonodo após co-cultura com DCs ativadas por LPS e incubadas com células alogênicas em apoptose (mDC+APO). As porcentagens indicadas se referem à população de células $\mathrm{CD} 4^{+}$. As porcentagens de células $\mathrm{CD} 4{ }^{+} \mathrm{CD} 25^{+}$de linfonodo expressando ou não Foxp3 foram determinadas como descritos nas tabelas 6 e 8 em anexo. Dados representativos de 2 experimentos. ${ }^{*} p<0,05$ (em relação à porcentagem de células obtidas de linfonodo (LN)). \#p<0,05, \#\#<0,01 (significativo entre os grupos indicados) (Testes ANOVA e Tukey). 
5. Discussão 


\section{Discussão}

As interações entre células Treg e células dendríticas têm despertado o interesse de muitos grupos de pesquisa nos últimos anos. Entender melhor como a interação entre estas células é capaz de alterar o curso de uma resposta imune, manter a população de células Treg na periferia, além da possibilidade da geração de células Treg antígeno especificas a partir destas interações são algumas das questões mais estudadas. Inúmeros trabalhos têm descrito diferentes necessidades para a expansão ou geração de células Treg através de sua interação com DCs. Neste contexto, o trabalho apresentado demonstra que as células Treg podem ser expandidas por células dendríticas em diferentes estados de ativação, tanto na presença quanto na ausência de antígenos alogênicos capturados pelas DCs na forma de células em apoptose.

A primeira preocupação no desenvolvimento do estudo foi garantir que a população obtida após a cultura de células de medula óssea na presença de GM-CSF era constituída essencialmente de células dendríticas. Para isso realizamos análises fenotípicas e funcionais destas células. Nossos resultados encontram-se em acordo com os relatos da literatura tanto no que se refere ao fenótipo das DCs obtidas quanto no que se refere à capacidade destas células apresentarem antígenos e estimularem respostas proliferativas de linfócitos T. Realizamos também análises visando caracterizar as células quanto ao seu estado de ativação. Demonstramos assim, que obtivemos uma população de células dendríticas imaturas, capazes de serem ativadas e exibir um fenótipo de células dendríticas maduras após estímulo. Tomados em conjunto, estes resultados nos dão segurança para afirmar que nosso protocolo nos permite obter células dendríticas.

Um dos pontos chave do presente trabalho é a utilização de células alogênicas em apoptose para determinar a influência de antígenos exógenos nas alterações ocorridas na população de células Treg após interação com DCs. A escolha da utilização de células alogênicas em apoptose como fonte de antígenos exógenos se deu na tentativa de obter 
uma condição experimental mais inclinada à geração de tolerância. Diversos estudos têm implicado células em apoptose na geração de tolerância periférica, possivelmente por sua capacidade de induzir propriedades tolerogênicas em células dendríticas (Bittencourt et al, 2001; Kleinclauss et al, 2006; Wang et al, 2006). No entanto, em nosso modelo experimental as células apoptóticas não parecem ter grande influência no estado de ativação das DCs, como evidenciado pelos resultados de citometria de fluxo e de dosagem de citocinas. Este fato, possivelmente, é uma decorrência do momento em que as DCs são incubadas com as células em apoptose. As células dendríticas ativadas já terminaram seu processo de maturação quando as células em apoptose são adicionadas à co-cultura. Sendo assim, as últimas não conseguem reverter o quadro de ativação das DCs. Por outro lado, quando utilizamos as DCs imaturas estas células não são posteriormente maturadas. Sendo assim, os efeitos moduladores das células em apoptose não são evidenciados. A função das células em apoptose no modelo experimental proposto, portanto, parece estar ligada ao provimento de antígenos exógenos que serão apresentados pelas DCs aos linfócitos T no decorrer da co-cultura. Apesar de nossos resultados indicarem que este seja o caso, não podemos descartar a possibilidade das células em apoptose estarem modulando outras moléculas e/ou citocinas não analisados neste estudo.

Além disso, era importante determinar se a capacidade fagocítica das DC imaturas e maduras era semelhante. Se este parâmetro fosse significativamente diferente entre as DCs imaturas e maduras os dados obtidos posteriormente poderiam ser interpretados equivocadamente. Ao realizarmos a quantificação da fagocitose pelas DCs imaturas e maduras notamos que não há diferenças entre elas no tocante à fagocitose de células alogênicas em apoptose. Estas análises nos deram o respaldo necessário para que pudéssemos analisar nossos resultados posteriores com maior tranqüilidade, eliminando a possibilidade de um erro experimental.

A utilização de células dendríticas em diferentes estados de ativação, tendo em mente que diferentes estados de ativação acarretam mudanças funcionais nestas células, nos 
levou a caracterizar, ao menos parcialmente, o microambiente onde o contato entre as DCs e as células de linfonodo se iniciaria. Sabidamente, o microambiente em que se dá a apresentação de antígeno é um fator importante, capaz de determinar como a resposta imune irá se desenvolver. Sendo assim, nossos resultados a respeito das citocinas produzidas pelas DCs e, portanto, presentes no microambiente durante a co-cultura entre DCs e células de linfonodo, nos trazem informações importantes.

A produção de IL-10, IL-12 e TNF- $\alpha$ pelas DCs nas diferentes condições experimentais seguiram um comportamento semelhante. A produção destas citocinas foi detectada apenas quando houve estimulação das DCs por LPS. Mais, esta produção não foi afetada pela adição de células alogênicas em apoptose à cultura. Após um estimulo de maturação, como o LPS, a produção de citocinas pró-inflamatórias como o TNF- $\alpha$ e a IL-12 pelas DCs é esperada. Quanto à produção de IL-10, podemos supor que esteja ligada a um mecanismo de controle da resposta inflamatória, iniciada pela produção de citocinas pró-inflamatórias. Apesar de esta explicação não estar formalmente demonstrada em nosso trabalho, há relatos na literatura descrevendo o mesmo fenômeno quanto à produção de IL-10 por DCs derivadas da medula óssea de camundongos quando estimuladas por LPS ou outros agonistas de Toll-like receptors (Boonstra et al, 2006; Samarasinghe et al, 2006).

A produção de TGF- $\beta$, por sua vez, demonstrou um comportamento muito diferente do observado na produção das outras citocinas. Nossos resultados demonstram uma produção constante de TGF- $\beta$ em todas as condições experimentais, não sendo esta produção modulada nem pela ativação das DCs por LPS nem pela adição de células alogênicas em apoptose. Estes resultados são inesperados e, portanto, não podem ser analisados de maneira simples. Inicialmente, o resultado esperado seria a diminuição da produção de TGF- $\beta$, uma citocina imunossupressora, à medida que as DCs fossem ativadas por LPS.

Uma possível explicação para estes resultados pode estar ligada às semelhanças entre macrófagos e DCs e à linhagem de camundongo utilizada. Estudos realizados com macrófagos de diferentes linhagens de camundongos têm demonstrado que as 
propriedades funcionais destas células são diferentes (Bastos et al, 2002; Mills et al, 2000). Os parâmetros utilizados nestes estudos são, principalmente, a produção diferencial de óxido nítrico e de TGF- $\beta$ pelos macrófagos de diferentes linhagens antes e após estímulo com LPS, interferon-y (IFN-y) ou os dois estímulos somados. Os resultados destes estudos demonstram que macrófagos de camundongos BALB/c produzem grandes quantidades de TGF- $\beta$ e pouco óxido nítrico, mesmo após estimulação, enquanto macrófagos de camundongos C57BL/6 produzem grandes quantidades de óxido nítrico e pouco TGF- $\beta$. Além disso, resultados obtidos analisando-se DCs derivadas da medula óssea de camundongos C57BL/6 deficientes na subunidade p40 da IL-12 demonstraram que estas células possuem um perfil de produção de TGF- $\beta$ e óxido nítrico muito semelhante ao encontrado em macrófagos de camundongos BALB/c, sugerindo que o comportamento observado em macrófagos pode ser extrapolado para o observado em DCs (Bastos et al, 2005).

Foi demonstrado recentemente que células dendríticas e macrófagos podem ser originados a partir das mesmas células precursoras presentes na medula óssea (Fogg et al, 2005). Outras semelhanças no desenvolvimento de DCs e macrófagos também são observadas. Os monócitos presentes na circulação são normalmente tidos como os precursores dos macrófagos teciduais. No entanto, dois grupos demonstraram que, em condições inflamatórias, monócitos podem dar origem a células de Langerhans na pele (Ginhoux et al, 2006) e a DCs caracterizadas pela expressão de CD11c e CD11b no baço (Naik et al, 2006). Sendo assim, podemos supor que a produção de TGF- $\beta$ observada em nossas condições experimentais reflete uma relação entre o comportamento de macrófagos e células dendríticas de camundongos BALB/c no tocante à produção desta citocina.

É interessante observar que o TGF- $\beta$ é uma das principais citocinas implicadas na geração de células Treg a partir de linfócitos T naïve em diferentes condições experimentais (Mucida et al, 2005; Kretschmer et al, 2005; Ochando et al, 2006; Luo et al, 2007). É importante notar que os efeitos do TGF- $\beta$ parecem ser extremamente potentes uma vez 
que a presença concomitante desta citocina e de citocinas capazes de induzir respostas imunes Th1 ou Th2 durante a apresentação de antígeno, diminuem apenas modestamente a conversão dos linfócitos T naïve em células Treg (Bettelli et al, 2006). Sendo assim, em nosso modelo esta citocina pode também agir de forma a inibir a geração de células $T$ efetoras, criando um ambiente favorável à expansão das células Treg. Além disso, o papel do TGF- $\beta$ em nosso modelo experimental pode ser o de manter a expressão de Foxp3 na população de células Treg após a sua expansão, como sugerido por Fantini et al (2004).

Nossos resultados demonstram que, independente da condição experimental analisada, há um aumento na porcentagem de células $C D 4^{+} \mathrm{CD} 25^{+}$Foxp $3^{+}$obtidas após a co-cultura, quando comparadas às porcentagens obtidas de linfonodos de animais naïve. Estudos têm demonstrado que células Treg são expandidas de maneira mais eficiente por DCs maduras derivadas da medula óssea do que por DCs imaturas (Yamazaki et al, 2003; Tarbell et al, 2004; Yamazaki et al, 2006). Nestes trabalhos os autores mostram ainda que tanto na presença quanto na ausência de antígenos exógenos a proliferação das células Treg é observada. Outros estudos demonstraram que DCs imaturas obtidas de baço de camundongos naïve caracterizadas fenotipicamente pela expressão de CD11c e CD11b, mesmo fenótipo encontrado nas DCs observadas neste estudo, estimulam a proliferação de células Treg na ausência de antígenos exógenos (Fisson et al, 2006). Por outro lado, a proliferação das células Treg de maneira antígeno inespecífica não é evidenciada quando são utilizados outros subtipos de células dendríticas. É importante notar que nos trabalhos citados acima a expansão das células Treg foi mais pronunciada na presença de IL-2.

Apesar de algumas diferenças experimentais em relação aos trabalhos citados acima, nossos resultados estão em acordo com os obtidos pelos autores, e demonstram que o aumento na porcentagem de células Treg, quando células de linfonodo são co-cultivadas com DCs, pode ocorrer de maneira independente da presença de antígeno ou do estado de ativação das DCs. Quanto ao aumento de proliferação das células Treg na presença de IL-2, apesar de ensaios para dosagem de IL-2 não terem sido realizados no presente trabalho, é 
plausível considerar que esta citocina esteja sendo produzida em pequenas quantidades durante as co-culturas uma vez que nestas há presença de linfócitos $T$, as principais células produtoras desta citocina.

Nossos dados demonstram um aumento da população de células Treg em resposta a antígenos próprios. No entanto, este aumento é ainda maior na presença de aloantígenos. Estes dados podem sugerir a presença de células Treg com especificidades antigênicas distintas em linfonodos de camundongos naïve. Uma das populações tem sua expansão preferencialmente estimulada pelo encontro com aloantígenos, enquanto a outra população é expandida preferencialmente pelo encontro com auto-antígenos. Uma interpretação alternativa destes dados, no entanto, pode sugerir que a presença de aloantígenos na cocultura atuaria ativando alguns linfócitos $\mathrm{T}$ naïve que produziriam maiores quantidades de IL-2. A maior quantidade de IL-2 na co-cultura poderia, por sua vez, estimular uma proliferação mais intensa das células Treg e/ou promover condições ótimas para a sua sobrevivência. Esta última interpretação, no entanto, não encontra respaldo em nossos dados de citometria de fluxo. Estes dados demonstram que na presença de aloantígeno a porcentagem de células $\mathrm{T} \mathrm{CD} 4^{+} \mathrm{CD} 25^{+}$Foxp3", um fenótipo característico de células ativadas e conseqüentemente produtoras de IL-2, não aumenta em relação às condições em que não há presença de aloantígeno.

É importante notar, no entanto, que no caso em que as células dendríticas estão ativadas e há presença de aloantígeno não observamos a mesma porcentagem de células Treg observada quando as DCs estão imaturas e há aloantígeno. É possível que a explicação para este fato resida no microambiente em que as interações entre DCs e Treg ocorrem. Como demonstrado na figura 8, o padrão de citocinas produzidos pelas DCs maduras difere substancialmente daquele produzido pelas DCs imaturas. Sendo assim, na primeira condição é possível que o micro-ambiente mais pró-inflamatório, em que foi detectada a presença de IL-12 e TNF- $\alpha$, possa influenciar negativamente a expansão de células Treg, explicando a diferença observada entre as duas condições. 
Há ainda uma outra possibilidade a ser considerada em relação ao aumento de células Treg na condição em que há DCs imaturas e aloantígeno. Neste caso, como não realizamos ensaios utilizando células singênicas em apoptose, não podemos descartar a hipótese de que a maior porcentagem de células Treg observada decorra de um efeito das células em apoptose nas DCs e, portanto, seja independente dos antígenos alogênicos. No entanto, nossos dados não demonstram qualquer alteração no estado de ativação ou no padrão de produção de citocinas pelas DCs imaturas quando incubadas com células em apoptose, enfraquecendo esta hipótese.

É interessante notar uma correlação inversa entre a população de células T CD $4^{+} \mathrm{CD} 25^{+} \mathrm{Foxp}^{+}$e a população de células $\mathrm{CD} 4^{+} \mathrm{CD} 25^{-} \mathrm{Foxp} 3^{+}$em nossos experimentos. Enquanto a primeira aumenta em todas as condições experimentais analisadas, notamos que a segunda segue o padrão inverso, ou seja, diminui em relação à população encontrada em linfonodos de camundongos naïve (exceção feita à condição em que há apenas DCs maduras) (figura 11C). Apesar de não termos evidências experimentais demonstrando que as células $\mathrm{CD}^{+} \mathrm{CD} 25^{-} \mathrm{Foxp}^{+}$tornam-se células $\mathrm{CD} 4^{+} \mathrm{CD} 25^{+} \mathrm{Foxp}^{+}$, é inevitável especular que este fenômeno esteja ocorrendo em nossas condições experimentais. Dessa forma, a mudança no perfil da população $C D 4^{+} C D 25^{+} F o x p 3^{+}$nos grupos experimentais em relação à população encontrada em linfonodos de camundongos naïve, seria resultado dessa conversão. A literatura acerca das células $\mathrm{T}$ CD4 ${ }^{+} \mathrm{CD} 25^{-} \mathrm{Foxp}^{+}$é restrita. No entanto, tem sido demonstrado que a expressão de Foxp3 é suficiente para induzir propriedades reguladoras em células $\mathrm{T} \mathrm{CD}^{+} \mathrm{CD} 25^{-}$(Hori, 2003). Se as células $\mathrm{CD} 4^{+} \mathrm{CD} 25^{-} \mathrm{Foxp} 3^{+}$de fato tornarem-se células $\mathrm{CD}^{+} \mathrm{CD} 25^{+} \mathrm{Foxp}^{+}$após a co-cultura com DCs, a elucidação dos mecanismos pelos quais esta mudança de fenótipo ocorre seria uma contribuição importante ao estudo das células Treg.

As alterações observadas nas diferentes condições experimentais no tocante à porcentagem de células Treg obtidas foram altamente reprodutíveis durante todo o decorrer do trabalho. Sendo assim, buscamos uma explicação para o aumento mais pronunciado 
desta população celular na condição em que as DCs estão imaturas e há presença de antígeno alogênico. Neste caso, é possível que a presença de antígenos alogênicos e de TGF- $\beta$, na ausência de outras citocinas, expliquem o fenômeno observado. Uma possível análise para esse evento baseia-se na seguinte hipótese: a presença de aloantígeno faria com que as células Treg específicas ao mesmo proliferassem. Esta proliferação somada à proliferação induzida por auto-antígenos aumentaria a proporção de células Treg obtidas em relação às condições em que não há aloantígenos. Além disso, o perfil de produção de citocinas pelas DCs, nesse caso, pode ser um fator importante para a expansão de células Treg, uma vez que a presença de TGF- $\beta$, na ausência de citocinas pró-inflamatórias como o TNF- $\alpha$ e a IL-12, pode favorecer a expansão desta população em detrimento de outras populações de linfócitos $\mathrm{T}$.

Foram realizados experimentos visando determinar se o aumento das células Treg nas diferentes condições experimentais seria fruto da expansão destas células presentes inicialmente na co-cultura ou fruto da geração de novo das mesmas a partir de células CD4 ${ }^{+}$CD25: Nossos resultados demonstram que, mesmo após a depleção de grande parte das células $\mathrm{CD} 4^{+} \mathrm{CD} 25^{+}$presentes no linfonodo, ainda se observa expansão da população de células $\mathrm{CD}^{+} \mathrm{CD} 25^{+} \mathrm{Foxp}^{+}$, independente das condições experimentais, em relação à quantidade de células $\mathrm{CD} 4^{+} \mathrm{CD} 25^{+}$iniciais. Este aumento, no entanto, é menor do que o observado quando utilizamos células totais de linfonodo para a realização da co-cultura. Outro aspecto importante observado nestes experimentos é o evidente aumento da população $\mathrm{CD}^{+} \mathrm{CD} 25^{+}$Foxp3- nas condições em que as DCs (imaturas e maduras) foram incubadas com aloantígeno (figura 14). Neste caso, podemos supor que a incubação das células de linfonodo, depletadas de células Treg, com as DCs levaria à ativação de linfócitos $\mathrm{T} \mathrm{CD4}^{+}$naïve e à conseqüente produção de altas quantidades de IL-2. A IL-2 produzida pelos linfócitos $C D 4^{+} \mathrm{CD} 25^{+}$Foxp3", por sua vez, estaria induzindo a proliferação tanto das células Treg contaminantes (a pequena percentagem que não foi eliminada) quanto das células efetoras ativadas pelo aloantígeno, explicando o aumento observado em ambas 
populações celulares. Como as DCs maduras possuem uma maior capacidade estimuladora de linfócito T naïve, notamos um maior aumento dos linfócitos $\mathrm{T}$ ativados nesta condição experimental.

Devido às limitações inerentes ao método utilizado para a depleção de células Treg, os dados apresentados devem ser observados cautelosamente. Após a depleção das células Treg ainda há uma população contaminante de células $\mathrm{CD}^{+} \mathrm{CD} 25^{+}$(aproximadamente $2 \%$ ) presente na fração de células $C D 4^{+} C D 25$. Sendo assim, é possível que o aumento observado na população $C D 4^{+} C D 25^{+} F o x p 3^{+}$decorra da expansão desta população contaminante. Em acordo com este fato, a menor porcentagem de células CD $4^{+}$CD $25^{+}$Foxp $3^{+}$observada quando as células $C D 4^{+} \mathrm{CD} 25^{+}$são depletadas antes da cocultura, sugere a expansão das células Treg presentes nos linfonodos de animais naïve como o principal mecanismo responsável pelo aumento observado em nossos experimentos. Sendo assim, nossos dados sugerem que a geração de novo de células $\mathrm{CD}^{+} \mathrm{CD} 25^{+} \mathrm{Foxp}^{+}$a partir de células $\mathrm{CD} 4^{+} \mathrm{CD} 25^{-}$não é responsável por uma parcela significativa do aumento na população de células Treg.

Como explicitado acima, a expansão das células $C D 4^{+} C D 25^{+}$Foxp $3^{+}$pode indicar a expansão da população contaminante $C D 4^{+} C D 25^{+}$presente na fração de células CD4 ${ }^{+}$CD25 antes da co-cultura. Apesar desta limitação experimental, a grande diferença observada na população $\mathrm{CD}^{+} \mathrm{CD} 25^{+}$Foxp3- demonstra que a depleção alterou os eventos que ocorrem durante a co-cultura em nosso modelo, sugerindo fortemente que a presença de células Treg no início da co-cultura é importante para que não haja ativação exacerbada das células T $\mathrm{CD}^{+}$naïve na presença de aloantígenos.

Apesar do grande volume de trabalhos investigando as interações entre células dendríticas e células Treg, há pouco consenso sobre as condições nas quais existe preferencialmente geração ou expansão destas células. É possível encontrar na literatura trabalhos em que a geração de células Treg a partir de linfócitos $T$ naïve ocorre em condições imunogênicas (Mucida et al, 2005) e em condições não imunogênicas (Apoustolo 
et al, 2004; Kretschmer et al, 2005). Existem também relatos descrevendo a expansão de populações de células Treg na presença de células dendríticas maduras (Yamazaki et al, 2003; Walker et al, 2003; Tarbell et al, 2004) e na presença de células dendríticas imaturas (Fisson et al, 2006). Além disso, existem relatos demonstrando que as células Treg proliferam em contato com células dendríticas na presença e na ausência de antígenos exógenos (Yamazaki et al, 2003; Fisson et al, 2006).

Analisando os dados da literatura em conjunto com os dados obtidos neste trabalho, podemos inferir que a geração ou expansão de células Treg se dá em condições muito diversas, de forma diferente do que ocorre para a geração e expansão de linfócitos T efetores. Aparentemente, as células Treg podem ser expandidas e/ou geradas tanto em condições desfavoráveis para a ativação de linfócitos T efetores, ou seja, condições em que há pouca inflamação, como em condições em que há ativação de linfócitos T efetores. Estes mecanismos parecem atuar para manter sempre disponível uma população de células Treg capaz de manter em xeque possíveis linfócitos T auto-reativos que não foram eliminados durante a seleção tímica e podem, eventualmente, ativar-se. Esta visão encontra suporte em trabalhos publicados recentemente demonstrando que a depleção de células Treg presentes na periferia de camundongos adultos desencadeia uma síndrome auto-imune derivada da ativação de linfócitos T específicos para antígenos próprios (Setoguchi et al, 2005; Kim et al, 2007).

Em resumo, nossos resultados demonstram que as células dendríticas, independente do seu estado de maturação, são capazes de expandir a população de células Treg. Além disso, é interessante notar que há condições em que o aumento da população de células $\mathrm{CD} 4^{+} \mathrm{CD} 25^{+} \mathrm{Foxp}^{+}$é favorecido. O conhecimento mais aprofundado das interações entre estes dois tipos celulares, e das condições ideais para a expansão da população de células CD $4^{+} \mathrm{CD} 25^{+} \mathrm{Foxp}^{+}$, é relevante à medida que a utilização desta população celular seja considerada como uma possibilidade terapêutica para conter a ativação exacerbada do sistema imune. 
6. Conclusões 


\section{Conclusões}

I. O protocolo utilizado permite a obtenção de células dendríticas imaturas que podem ser maturadas pelo estímulo com LPS. As células dendríticas imaturas e maduras são capazes de fagocitar células alogênicas em apoptose de maneira semelhante, sendo que a interação entre estas células não altera o estado de ativação das DCs.

II. As DCs obtidas são capazes de estimular a proliferação de linfócitos T. Quanto à produção de citocinas, produzem IL-12, IL-10 e TNF- $\alpha$ quando estimuladas por LPS. Tanto as DCs maduras quanto as imaturas produzem TGF- $\beta$ em quantidades semelhantes.

III. A co-cultura de células de linfonodo com DCs induz um aumento na população de células $\mathrm{CD}^{+} \mathrm{CD} 25^{+} \mathrm{Foxp}^{+}$. Este aumento é mais pronunciado na condição experimental em que as DCs estão imaturas e há antígenos alogênicos.

IV. Nossos dados sugerem que o aumento observado na população de células $\mathrm{CD}^{+} \mathrm{CD} 25^{+} \mathrm{Foxp}^{+}$se deve, principalmente, à proliferação desta população celular após a co-cultura de células de linfonodo com DCs. 
7. Referências 


\section{Referências}

ALLMAN D, DALOD M, ASSELIN-PATUREL C, DELALE T, ROBBINS SH, TRINCHIERI G, BIRON CA, KASTNER P, CHAN S. Ikaros is required for plasmacytoid dendritic cell differentiation. Blood. 108(13):4025-34, 2006.

APOSTOLOU I, VON BOEHMER $\mathrm{H}$. In vivo instruction of suppressor commitment in naive T cells. J Exp Med. 199(10):1401-8, 2004.

ARDAVIN C, WU L, LI CL, SHORTMAN K. Thymic dendritic cells and T cells develop simultaneously within the thymus from a common precursor population. Nature. 362:761763, 1993.

ASCHENBRENNER K, D'CRUZ LM, VOLLMANN EH, HINTERBERGER M, EMMERICH J, SWEE LK, ROLINK A, KLEIN L. Selection of Foxp3(+) regulatory T cells specific for self antigen expressed and presented by Aire $(+)$ medullary thymic epithelial cells. Nat Immunol. 8(4):351-8, 2007.

BANCHEREAU J, BRIERE F, CAUX C, DAVOUST J, LEBECQUE S, LIU YJ, PULENDRAN B, PALUCKA K. Immunobiology of dendritic cells. Annu Rev Immunol. 18:767-811, 2000.

BASTOS KR, ALVAREZ JM, MARINHO CR, RIZZO LV, LIMA MR. Macrophages from IL12p40-deficient mice have a bias toward the M2 activation profile. J Leukoc Biol. 71(2):2718, 2002.

BASTOS KR, DE DEUS VIEIRA DE MORAES L, ZAGO CA, MARINHO CR, RUSSO M, ALVAREZ JM, D'IMPERIO LIMA MR. Analysis of the activation profile of dendritic cells derived from the bone marrow of interleukin-12/interleukin-23-deficient mice. Immunology. 114(4):499-506, 2005.

BENNETT CL, CHRISTIE J, RAMSDELL F, BRUNKOW ME, FERGUSON PJ, WHITESELL L, KELLY TE, SAULSBURY FT, CHANCE PF, OCHS HD. The immune dysregulation, polyendocrinopathy, enteropathy, X-linked syndrome (IPEX) is caused by mutations of FOXP3. Nat Genet. 27(1):20-1, 2001.

BETTELLI E, CARRIER Y, GAO W, KORN T, STROM TB, OUKKA M, WEINER HL, KUCHROO VK. Reciprocal developmental pathways for the generation of pathogenic effector TH17 and regulatory T cells. Nature. 2006 May 11;441(7090):235-8.

BITTENCOURT MC, PERRUCHE S, CONTASSOT E, FRESNAY S, BARON MH, ANGONIN $R$, AUBIN F, HERVE P, TIBERGHIEN P, SAAS P. Intravenous injection of apoptotic leukocytes enhances bone marrow engraftment across major histocompatibility barriers.

Blood. 98(1):224-30, 2001.

BJORCK P, KINCADE PW. CD19+ pro-B cells can give rise to dendritic cells in vitro. J Immunol. 161:5795-5799, 1998.

BONASIO R, SCIMONE ML, SCHAERLI P, GRABIE N, LICHTMAN AH, VON ANDRIAN UH. Clonal deletion of thymocytes by circulating dendritic cells homing to the thymus. Nat Immunol. 7(10):1092-100, 2006.

BONIFAZ L, BONNYAY D, MAHNKE K, RIVERA M, NUSSENZWEIG MC, STEINMAN RM. Efficient targeting of protein antigen to the dendritic cell receptor DEC-205 in the steady state 
leads to antigen presentation on major histocompatibility complex class I products and peripheral CD8+ T cell tolerance. J Exp Med. 196(12):1627-38, 2002.

BOONSTRA A, RAJSBAUM R, HOLMAN M, MARQUES R, ASSELIN-PATUREL C, PEREIRA JP, BATES EE, AKIRA S, VIEIRA P, LIU YJ, TRINCHIERI G, O'GARRA A. Macrophages and myeloid dendritic cells, but not plasmacytoid dendritic cells, produce IL-10 in response to MyD88- and TRIF-dependent TLR signals, and TLR-independent signals. $J$ Immunol. 177(11):7551-8, 2006.

BROCKER T, RIEDINGER M, KARJALAINEN K. Targeted expression of major histocompatibility complex (MHC) class II molecules demonstrates that dendritic cells can induce negative but not positive selection of thymocytes in vivo. J Exp Med. 185(3):541-50, 1997.

BURCHILL MA, YANG J, VOGTENHUBER C, BLAZAR BR, FARRAR MA. IL-2 receptor beta-dependent STAT5 activation is required for the development of Foxp3+ regulatory $T$ cells. J Immunol. 178(1):280-90, 2007.

CAO W, LIU YJ. Innate immune functions of plasmacytoid dendritic cells. Curr Opin Immunol. 19(1):24-30, 2007.

CONG Y, KONRAD A, IQBAL N, HATTON RD, WEAVER CT, ELSON CO. Generation of Antigen-Specific, Foxp3-Expressing CD4+ Regulatory $\mathrm{T}$ Cells by Inhibition of APC Proteosome Function. J Immunol. 174(5):2787-95, 2005.

CROWLEY M, INABA K, STEINMAN RM. Dendritic cells are the principal cells in mouse spleen bearing immunogenic fragments of foreign proteins. J Exp Med. 172(1):383-6, 1990.

CUROTTO DE LAFAILLE MA, LINO AC, KUTCHUKHIDZE N, LAFAILLE JJ. CD25- T cells generate $\mathrm{CD} 25+$ Foxp3+ regulatory $\mathrm{T}$ cells by peripheral expansion. $J$ Immunol. 173(12):7259-68, 2004.

D'AMICO A, WU L. The early progenitors of mouse dendritic cells and plasmacytoid predendritic cells are within the bone marrow hemopoietic precursors expressing Flt3. J Exp Med. 198(2):293-303, 2003.

DEN HAAN JM, LEHAR SM, BEVAN MJ. CD8(+) but not CD8(-) dendritic cells cross-prime cytotoxic T cells in vivo. J Exp Med. 192(12):1685-96, 2000.

DIEU MC, VANBERVLIET B, VICARI A, BRIDON JM, OLDHAM E, AIT-YAHIA S, BRIERE F, ZLOTNIK A, LEBECQUE S, CAUX C. Selective recruitment of immature dendritic cells by distinct chemokines expressed in different anatomic sites. J Exp Med. 188: 373-86, 1998

DUDZIAK D, KAMPHORST AO, HEIDKAMP GF, BUCHHOLZ VR, TRUMPFHELLER C, YAMAZAKI S, CHEONG C, LIU K, LEE HW, PARK CG, STEINMAN RM, NUSSENZWEIG MC. Differential antigen processing by dendritic cell subsets in vivo. Science. 315(5808):107-11, 2007.

FALLARINO F, GROHMANN U, HWANG KW, ORABONA C, VACCA C, BIANCHI R, BELLADONNA ML, FIORETTI MC, ALEGRE ML, PUCCETTI P. Modulation of tryptophan catabolism by regulatory T cells. Nat Immunol. 4(12):1206-12, 2003. 
FANTINI MC, BECKER C, MONTELEONE G, PALLONE F, GALLE PR, NEURATH MF. Cutting edge: TGF-beta induces a regulatory phenotype in CD4+CD25- T cells through Foxp3 induction and down-regulation of Smad7. J Immunol. 172(9):5149-53, 2004.

FISSON S, DJELTI F, TRENADO A, BILLIARD F, LIBLAU R, KLATZMANN D, COHEN JL, SALOMON BL. Therapeutic potential of self-antigen-specific CD4+ CD25+ regulatory $T$ cells selected in vitro from a polyclonal repertoire. Eur J Immunol. 36(4):817-27, 2006.

FOGG DK, SIBON C, MILED C, JUNG S, AUCOUTURIER P, LITTMAN DR, CUMANO A, GEISSMANN F. A clonogenic bone marrow progenitor specific for macrophages and dendritic cells. Science. 311(5757):83-7, 2006.

FONTENOT JD, GAVIN MA, RUDENSKY AY. Foxp3 programs the development and function of CD4+CD25+ regulatory T cells. Nat Immunol. 4(4):330-6, 2003.

FONTENOT JD, RASMUSSEN JP, GAVIN MA, RUDENSKY AY. A function for interleukin 2 in Foxp3-expressing regulatory T cells. Nat Immunol. 6(11):1142-51, 2005.

GABRIELE L, FRAGALE A, BORGHI P, SESTILI P, STELLACCI E, VENDITTI $M$, SCHIAVONI G, SANCHEZ M, BELARDELLI F, BATTISTINI A. IRF-1 deficiency skews the differentiation of dendritic cells toward plasmacytoid and tolerogenic features. J Leukoc Biol. 80(6):1500-11, 2006.

GAVIN MA, TORGERSON TR, HOUSTON E, DEROOS P, HO WY, STRAY-PEDERSEN A, OCHELTREE EL, GREENBERG PD, OCHS HD, RUDENSKY AY. Single-cell analysis of normal and FOXP3-mutant human T cells: FOXP3 expression without regulatory $\mathrm{T}$ cell development. Proc Natl Acad Sci U S A. 103(17):6659-64, 2006.

GINHOUX F, TACKE F, ANGELI V, BOGUNOVIC M, LOUBEAU M, DAI XM, STANLEY ER, RANDOLPH GJ, MERAD M. Langerhans cells arise from monocytes in vivo. Nat Immunol. 7(3):265-73, 2006.

GUERMONPREZ P, VALLADEAU J, ZITVOGEL L, THÉRY C, AMIGORENA S. Antigen presentation and $T$ cell stimulation by dendritic cells. Annu Rev Immunol. 20: 621-667, 2002.

GURNEY AL, MARSTERS SA, HUANG RM, PITTI RM, MARK DT, BALDWIN DT, GRAY AM, DOWD AD, BRUSH AD, HELDENS AD, SCHOW AD, GODDARD AD, WOOD WI, BAKER KP, GODOWSKI PJ, ASHKENAZI A. Identification of a new member of the tumor necrosis factor family and its receptor, a human ortholog of mouse GITR. Curr Biol. 9(4):215-8, 1999.

HARRINGTON LE, HATTON RD, MANGAN PR, TURNER H, MURPHY TL, MURPHY KM, WEAVER CT. Interleukin 17-producing CD4+ effector T cells develop via a lineage distinct from the T helper type 1 and 2 lineages. Nat Immunol. 2005 Nov;6(11):1123-32.

HAWIGER D, INABA K, DORSETT Y, GUO M, MAHNKE K, RIVERA M, RAVETCH JV, STEINMAN RM, NUSSENZWEIG MC. Dendritic cells induce peripheral $T$ cell unresponsiveness under steady state conditions in vivo. J Exp Med. 194(6):769-79, 2001.

HORI S, NOMURA T, SAKAGUCHI S. Control of regulatory T cell development by the transcription factor Foxp3. Science. 299(5609):1057-61, 2003. 
INABA K, METLAY JP, CROWLEY MT, STEINMAN RM. Dendritic cells pulsed with protein antigens in vitro can prime antigen-specific, MHC-restricted $\mathrm{T}$ cells in situ. $\mathbf{J}$ Exp Med. 172(2):631-40, 1990.

INABA K, STEINMAN RM, VAN VOORHIS WC, MURAMATSU S. Dendritic cells are critical accessory cells for thymus-dependent antibody responses in mouse and in man. Proc Natl Acad Sci USA. 80(19):6041-5, 1983.

INABA K, WITMER MD, STEINMAN RM. Clustering of dendritic cells, helper T lymphocytes, and histocompatible $B$ cells during primary antibody responses in vitro. J Exp Med. 160(3):858-76, 1984.

INABA K, YOUNG JW, STEINMAN RM. Direct activation of CD8+ cytotoxic T lymphocytes by dendritic cells. J Exp Med. 166(1):182-94, 1987.

ITO T, WANG YH, LIU YJ. Plasmacytoid dendritic cell precursors/type I interferon-producing cells sense viral infection by Toll-like receptor (TLR) 7 and TLR9. Springer Semin Immunopathol. 26(3):221-9, 2005.

ITOH M, TAKAHASHI T, SAKAGUCHI N, KUNIYASU Y, SHIMIZU J, OTSUKA $F$, SAKAGUCHI S. Thymus and autoimmunity: production of CD25+CD4+ naturally anergic and suppressive $T$ cells as a key function of the thymus in maintaining immunologic selftolerance. J Immunol. 162(9):5317-26, 1999.

JONULEIT H, SCHMITT E, SCHULER G, KNOP J, ENK AH. Induction of interleukin-10 producing, nonproliferanting CD4 $\mathrm{T}$ cells with regulatory properties by repetitive stimulation with allogeneic immature human dendritic cells. J Exp Med. 192(9):1213-22, 2000.

JORDAN MS, BOESTEANU A, REED AJ, PETRONE AL, HOLENBECK AE, LERMAN MA, NAJI A, CATON AJ. Thymic selection of CD4+CD25+ regulatory $T$ cells induced by an agonist self-peptide. Nat Immunol. 2(4):301-6, 2001.

KHATTRI R, COX T, YASAYKO SA, RAMSDELL F. An essential role for Scurfin in CD4+CD25+ T regulatory cells. Nat Immunol. 4(4):337-42, 2003.

KIM JM, RASMUSSEN JP, RUDENSKY AY. Regulatory T cells prevent catastrophic autoimmunity throughout the lifespan of mice. Nat Immunol. 8(2):191-7, 2007.

KLEINCLAUSS F, PERRUCHE S, MASSON E, DE CARVALHO BITTENCOURT M, BIICHLE S, REMY-MARTIN JP, FERRAND C, MARTIN M, BITTARD H, CHALOPIN JM, SEILLES E, TIBERGHIEN P, SAAS P. Intravenous apoptotic spleen cell infusion induces a TGF-beta-dependent regulatory T-cell expansion. Cell Death Differ. 13(1):41-52, 2006.

KRETSCHMER K, APOSTOLOU I, HAWIGER D, KHAZAIE K, NUSSENZWEIG MC, VON BOEHMER $\mathrm{H}$. Inducing and expanding regulatory $T$ cell populations by foreign antigen. Nat Immunol. 6(12):1219-27, 2005.

KYEWSKI BA, FATHMAN CG, ROUSE RV. Intrathymic presentation of circulating non-MHC antigens by medullary dendritic cells. An antigen-dependent microenvironment for $\mathrm{T}$ cell differentiation. J Exp Med. 163(2):231-46, 1986.

LEVINGS MK, SANGREGORIO R, SARTIRANA C, MOSCHIN AL, BATTAGLIA M, ORBAN PC, RONCAROLO MG. Human CD25+CD4+ T suppressor cell clones produce transforming 
growth factor beta, but not interleukin 10, and are distinct from type $1 \mathrm{~T}$ regulatory cells. $\mathbf{J}$ Exp Med. 196(10):1335-46, 2002.

LIANG S, ALARD P, ZHAO Y, PARNELL S, CLARK SL, KOSIEWICZ MM. Conversion of CD4+ CD25- cells into CD4+ CD25+ regulatory T cells in vivo requires B7 costimulation, but not the thymus. J Exp Med. 201(1):127-37, 2005.

LIU K, IYODA T, SATERNUS M, KIMURA Y, INABA K, STEINMAN RM. Immune tolerance after delivery of dying cells to dendritic cells in situ. J Exp Med. 196(8):1091-7, 2002.

LUO X, TARBELL KV, YANG H, POTHOVEN K, BAILEY SL, DING R, STEINMAN RM, SUTHANTHIRAN M. Dendritic cells with TGF-beta1 differentiate naive CD4+CD25- T cells into islet-protective Foxp3+ regulatory T cells. Proc Natl Acad Sci USA. 104(8):2821-2826, 2007.

MACATONIA SE, TAYLOR PM, KNIGHT SC, ASKONAS BA. Primary stimulation by dendritic cells induces antiviral proliferative and cytotoxic $T$ cell responses in vitro. J Exp Med. 169(4):1255-64, 1989.

MALOY KJ, SALAUN L, CAHILL R, DOUGAN G, SAUNDERS NJ, POWRIE F. CD4+CD25+ $T(R)$ cells suppress innate immune pathology through cytokine-dependent mechanisms. J Exp Med. 197(1):111-9, 2003.

MANZ MG, TRAVER D, MIYAMOTO T, WEISSMAN IL, AKASHI K. Dendritic cell potentials of early lymphoid and myeloid progenitors. Blood. 97(11):3333-41, 2001.

MCHUGH RS, WHITTERS MJ, PICCIRILLO CA, YOUNG DA, SHEVACH EM, COLLINS M, BYRNE MC. CD4(+)CD25(+) immunoregulatory T cells: gene expression analysis reveals a functional role for the glucocorticoid-induced TNF receptor. Immunity. 16(2):311-23, 2002.

MILLS CD, KINCAID K, ALT JM, HEILMAN MJ, HILL AM. M-1/M-2 macrophages and the Th1/Th2 paradigm. J Immunol. 164(12):6166-73, 2000.

MIN WP, ZHOU D, ICHIM TE, STREJAN GH, XIA X, YANG J, HUANG X, GARCIA B, WHITE D, DUTARTRE P, JEVNIKAR AM, ZHONG R. Inhibitory feedback loop between tolerogenic dendritic cells and regulatory $\mathrm{T}$ cells in transplant tolerance. $\mathbf{J}$ Immunol. 170(3):1304-12, 2003.

MUCIDA D, KUTCHUKHIDZE N, ERAZO A, RUSSO M, LAFAILLE JJ, CUROTTO DE LAFAILLE MA. Oral tolerance in the absence of naturally occurring Tregs. J Clin Invest. 115(7):1923-33, 2005.

NAIK SH, METCALF D, VAN NIEUWENHUIJZE A, WICKS I, WU L, O'KEEFFE M, SHORTMAN K. Intrasplenic steady-state dendritic cell precursors that are distinct from monocytes. Nat Immunol. 7(6):663-71, 2006.

NAKAMURA K, KITANI A, STROBER W. Cell contact-dependent immunosuppression by CD4(+)CD25(+) regulatory $\mathrm{T}$ cells is mediated by cell surface-bound transforming growth factor beta. J Exp Med. 194(5):629-44, 2001.

NISHIZUKA Y, SAKAKURA T. Thymus and reproduction: sex-linked dysgenesia of the gonad after neonatal thymectomy in mice. Science. 166(906):753-755, 1969. 
NOCENTINI G, GIUNCHI L, RONCHETTI S, KRAUSZ LT, BARTOLI A, MORACA R, MIGLIORATI G, RICCARDI C. A new member of the tumor necrosis factor/nerve growth factor receptor family inhibits $T$ cell receptor-induced apoptosis. Proc Natl Acad Sci USA. 94(12):6216-21, 1997.

OCHANDO JC, HOMMA C, YANG Y, HIDALGO A, GARIN A, TACKE F, ANGELI V, LI Y, BOROS $P$, DING $Y$, JESSBERGER R, TRINCHIERI G, LIRA SA, RANDOLPH GJ, BROMBERG JS. Alloantigen-presenting plasmacytoid dendritic cells mediate tolerance to vascularized grafts. Nat Immunol. 7(6):652-62, 2006.

PAUST S, LU L, MCCARTY N, CANTOR H. Engagement of B7 on effector T cells by regulatory T cells prevents autoimmune disease. Proc Natl Acad Sci USA. 101(28):10398403, 2004.

PICCIRILLO CA, LETTERIO JJ, THORNTON AM, MCHUGH RS, MAMURA M, MIZUHARA $\mathrm{H}$, SHEVACH EM. CD4(+)CD25(+) regulatory T cells can mediate suppressor function in the absence of transforming growth factor beta1 production and responsiveness. J Exp Med. 196(2):237-46, 2002.

POOLEY JL, HEATH WR, SHORTMAN K. Cutting edge: intravenous soluble antigen is presented to CD4 T cells by CD8- dendritic cells, but cross-presented to CD8 T cells by CD8+ dendritic cells. J Immunol. 166(9):5327-30, 2001.

READ S, GREENWALD R, IZCUE A, ROBINSON N, MANDELBROT D, FRANCISCO L, SHARPE AH, POWRIE F. Blockade of CTLA-4 on CD4+CD25+ regulatory T cells abrogates their function in vivo. J Immunol. 177(7):4376-83, 2006.

READ S, MALMSTROM V, POWRIE F. Cytotoxic T Iymphocyte-associated antigen 4 plays an essential role in the function of $\mathrm{CD} 25(+) \mathrm{CD} 4(+)$ regulatory cells that control intestinal inflammation. J Exp Med. 192(2):295-302, 2000.

REIS E SOUSA C. Dendritic cells in a mature age. Nat Rev Immunol. 6(6):476-83, 2006.

SADLACK B, MERZ H, SCHORLE H, SCHIMPL A, FELLER AC, HORAK I. Ulcerative colitislike disease in mice with a disrupted interleukin-2 gene. Cell. 75(2):253-61, 1993.

SAKAGUCHI S, SAKAGUCHI N, ASANO M, ITOH M, TODA M. Immunologic self-tolerance maintained by activated T cells expressing IL-2 receptor alpha-chains (CD25). Breakdown of a single mechanism of self-tolerance causes various autoimmune diseases. J Immunol. 155(3):1151-1164, 1995.

SAMARASINGHE R, TAILOR P, TAMURA T, KAISHO T, AKIRA S, OZATO K. Induction of an anti-inflammatory cytokine, IL-10, in dendritic cells after toll-like receptor signaling. $\mathbf{J}$ Interferon Cytokine Res. 26(12):893-900, 2006.

SCHNORRER P, BEHRENS GM, WILSON NS, POOLEY JL, SMITH CM, EL-SUKKARI D, DAVEY G, KUPRESANIN F, LI M, MARASKOVSKY E, BELZ GT, CARBONE FR, SHORTMAN K, HEATH WR, VILLADANGOS JA. The dominant role of CD8+ dendritic cells in cross-presentation is not dictated by antigen capture. Proc Natl Acad Sci USA. 103(28):10729-34, 2006.

SCHOTTE R, RISSOAN MC, BENDRISS-VERMARE N, BRIDON JM, DUHEN T, WEIJER K, BRIERE F, SPITS $H$. The transcription factor Spi-B is expressed in plasmacytoid DC precursors and inhibits T-, B-, and NK-cell development. Blood. 101(3):1015-23, 2003. 
SETOGUCHI R, HORI S, TAKAHASHI T, SAKAGUCHI S. Homeostatic maintenance of natural Foxp3(+) CD25(+) CD4(+) regulatory T cells by interleukin (IL)-2 and induction of autoimmune disease by IL-2 neutralization. J Exp Med. 201(5):723-35, 2005.

SHIMIZU J, YAMAZAKI S, TAKAHASHI T, ISHIDA Y, SAKAGUCHI S. Stimulation of CD25(+)CD4(+) regulatory T cells through GITR breaks immunological self-tolerance. Nat Immunol. 3(2):135-42, 2002.

SHORTMAN K, LIU YJ. Mouse and human dendritic cell subtypes. Nat Rev Immunol. 2(3):151-61, 2002.

SHORTMAN K, NAIK SH. Steady-state and inflammatory dendritic-cell development. Nat Rev Immunol. 7(1):19-30, 2007.

SPORRI R, REIS E SOUSA C. Inflammatory mediators are insufficient for full dendritic cell activation and promote expansion of CD4+ $\mathrm{T}$ cell populations lacking helper function. Nat Immunol. 6(2):163-70, 2005.

STEINBRINK K, JONULEIT H, MULLER G, SCHULER G, KNOP J, ENK AH. Interluekin-10 treated human dendritic cells induce a melanoma-antigen-specific anergy in CD8 T cells resulting in a failure to lyse tumor cells. Blood. 93:1634-42, 1999.

STEINBRINK K, WOLFL M, JONULEIT H, KNOP J, ENK AH. Induction of tolerance by IL-10 treated dendritic cells. J Immunol. 159:4772-80,1997.

STEINMAN RM, WITMER MD. Lymphoid dendritic cells are potent stimulators of the primary mixed leukocyte reaction in mice. Proc Natl Acad Sci USA. 75(10):5132-6,1978.

STEINMAN RM, HAWIGER D, NUSSENZWEIG MC. Tolerogenic dendritic cells. Annu Rev Immunol. 21:685-711, 2003.

STEINMAN RM, ADAMS JC, COHN ZA. Identification of a novel cell type in peripheral lymphoid organs of mice. IV. Identification and distribution in mouse spleen. J Exp Med. 141:804-820, 1975.

STEINMAN RM, COHN ZA. Identification of a novel cell type in peripheral lymphoid organs of mice. I. Morphology, quantitiation, tissue distribution. J Exp Med. 137:1142-1162, 1973.

STEINMAN RM, COHN ZA. Identification of a novel cell type in peripheral lymphoid organs of mice. II. Functinal properties in vitro. J Exp Med. 139:380-397, 1974.

STEINMAN RM, LUSTIG DS, COHN ZA. Identification of a novel cell type in peripheral lymphoid organs of mice. III. Functional properties in vivo. J Exp Med. 139:1431-1445, 1974.

SURI-PAYER E, AMAR AZ, THORNTON AM, SHEVACH EM. CD4+CD25+ T cells inhibit both the induction and effector function of autoreactive $T$ cells and represent a unique lineage of immunoregulatory cells. J Immunol. 160(3):1212-8, 1998.

SUZUKI H, KUNDIG TM, FURLONGER C, WAKEHAM A, TIMMS E, MATSUYAMA T, SCHMITS R, SIMARD JJ, OHASHI PS, GRIESSER H. Deregulated T cell activation and autoimmunity in mice lacking interleukin-2 receptor beta. Science. 268(5216):1472-6, 1995.

SVENSSON M, MAROOF A, ATO M, KAYE PM. Stromal cells direct local differentiation of regulatory dendritic cells. Immunity. 21(6):805-16, 2004. 
TADOKORO CE, SHAKHAR G, SHEN S, DING Y, LINO AC, MARAVER A, LAFAILLE JJ, DUSTIN ML. Regulatory T cells inhibit stable contacts between CD4+ T cells and dendritic cells in vivo. J Exp Med. 203(3):505-11, 2006.

TAKAHASHI T, KUNIYASU Y, TODA M, SAKAGUCHI N, ITOH M, IWATA M, SHIMIZU J, SAKAGUCHI S. Immunologic self-tolerance maintained by CD25+CD4+ naturally anergic and suppressive $T$ cells: induction of autoimmune disease by breaking their anergic/suppressive state. Int Immunol. 10(12):1969-80, 1998.

TAKAHASHI T, TAGAMI T, YAMAZAKI S, UEDE T, SHIMIZU J, SAKAGUCHI N, MAK TW, SAKAGUCHI S. Immunologic self-tolerance maintained by CD25(+)CD4(+) regulatory T cells constitutively expressing cytotoxic $T$ lymphocyte-associated antigen 4. J Exp Med. 192(2):303-10, 2000.

TANG Q, ADAMS JY, TOOLEY AJ, BI M, FIFE BT, SERRA P, SANTAMARIA P, LOCKSLEY $\mathrm{RM}, \mathrm{KRUMMEL}$ MF, BLUESTONE JA. Visualizing regulatory $\mathrm{T}$ cell control of autoimmune responses in nonobese diabetic mice. Nat Immunol. 7(1):83-92, 2006.

TANG Q, BODEN EK, HENRIKSEN KJ, BOUR-JORDAN H, BI M, BLUESTONE JA. Distinct roles of CTLA-4 and TGF-beta in CD4+CD25+ regulatory $\mathrm{T}$ cell function. Eur $\mathbf{J}$ Immunol. 34(11):2996-3005, 2004.

TARBELL KV, PETIT L, ZUO X, TOY P, LUO X, MQADMI A, YANG H, SUTHANTHIRAN M, MOJSOV S, STEINMAN RM. Dendritic cell-expanded, islet-specific CD4+ CD25+ CD62L+ regulatory T cells restore normoglycemia in diabetic NOD mice. J Exp Med. 204(1):191-201, 2007.

TARBELL KV, YAMAZAKI S, OLSON K, TOY P, STEINMAN RM. CD25+ CD4+ T cells, expanded with dendritic cells presenting a single autoantigenic peptide, suppress autoimmune diabetes. J Exp Med. 199(11):1467-77, 2004.

THORNTON AM, SHEVACH EM. CD4+CD25+ immunoregulatory $T$ cells suppress polyclonal $\mathrm{T}$ cell activation in vitro by inhibiting interleukin 2 production. $J$ Exp Med. 188(2):287-96, 1998.

TRAVER D, AKASHI K, MANZ M, MERAD M, MIYAMOTO T, ENGLEMAN EG, WEISSMAN IL. Development of CD8a-positive dendritic cells from a common myeloid progenitor. Science. 290:2152-54, 2000.

TRINCHIERI G. Pillars of immunology: The birth of a cell type. J Immunol. 178(1):3-4, 2007.

UHLIG HH, COOMBES J, MOTTET C, IZCUE A, THOMPSON C, FANGER A, TANNAPFEL A, FONTENOT JD, RAMSDELL F, POWRIE F. Characterization of Foxp3+CD4+CD25+ and IL-10-secreting CD4+CD25+ T cells during cure of colitis. J Immunol. 177(9):5852-60, 2006.

URAUSHIHARA K, KANAI T, KO K, TOTSUKA T, MAKITA S, IIYAMA R, NAKAMURA T, WATANABE M. Regulation of murine inflammatory bowel disease by CD25+ and CD25CD4+ glucocorticoid-induced TNF receptor family-related gene+ regulatory $\mathrm{T}$ cells. J Immunol. 171(2):708-16, 2003.

WAKKACH A, FOURNIER N, BRUN V, BREITTMAYER JP, COTTREZ F, GROUX H. Characterization of dendritic cells that induce tolerance and $T$ regulatory 1 cell differentiation in vivo. Immunity. 18(5):605-17, 2003. 
WALKER LS, CHODOS A, EGGENA M, DOOMS H, ABBAS AK. Antigen-dependent proliferation of CD4+ CD25+ regulatory T cells in vivo. J Exp Med. 198(2):249-58, 2003.

WANG Z, LARREGINA AT, SHUFESKY WJ, PERONE MJ, MONTECALVO A, ZAHORCHAK AF, THOMSON AW, MORELLI AE. Use of the inhibitory effect of apoptotic cells on dendritic cells for graft survival via T-cell deletion and regulatory $T$ cells. Am J Transplant. 6(6):1297-311, 2006.

WILDIN RS, SMYK-PEARSON S, FILIPOVICH AH. Clinical and molecular features of the immunodysregulation, polyendocrinopathy, enteropathy, $X$ linked (IPEX) syndrome. J Med Genet. 39(8):537-45, 2002.

WU L, D'AMICO A, HOCHREIN H, O'KEEFFE M, SHORTMAN K, LUCAS K. Development of thymic and splenic dendritic cell populations from different hemopoietic precursors. Blood. 98(12):3376-82, 2001.

YAMAZAKI S, IYODA T, TARBELL K, OLSON K, VELINZON K, INABA K, STEINMAN RM. Direct expansion of functional CD25+ CD4+ regulatory $\mathrm{T}$ cells by antigen-processing dendritic cells. J Exp Med. 21;198(2):235-47, 2003.

YAMAZAKI S, PATEL M, HARPER A, BONITO A, FUKUYAMA H, PACK M, TARBELL KV, TALMOR M, RAVETCH JV, INABA K, STEINMAN RM. Effective expansion of alloantigenspecific Foxp3+ CD25+ CD4+ regulatory T cells by dendritic cells during the mixed leukocyte reaction. Proc Natl Acad Sci USA. 103(8):2758-63, 2006.

ZHANG X, IZIKSON L, LIU L, WEINER HL. Activation of CD25(+)CD4(+) regulatory T cells by oral antigen administration. J Immunol. 167(8):4245-53, 2001. 
8. Anexos 


\section{Anexos}

Tabela 1. Porcentagens das diferentes subpopulações de células dendríticas obtidas (definidas por citometria de fluxo). Dados referentes a 4 experimentos realizados.

\section{Subpopulações de células dendríticas (\%)}

\begin{tabular}{|c|c|c|c|c|c|}
\hline & Experimento 1 & Experimento 2 & Experimento 3 & Experimento 4 & $\begin{array}{c}\text { Media } \pm \\
\text { desvio } \\
\text { padrão }\end{array}$ \\
\hline $\mathrm{CD}_{11 c^{+} \mathrm{CD} 11 \mathrm{~b}^{+}}$ & 72,15 & 70,45 & 73,00 & 82,09 & $74,42 \pm 5,22$ \\
\hline CD11c ${ }^{+} \mathrm{CD}^{+}$ & 0,38 & 2,22 & 1,26 & 1,04 & $1,22 \pm 0,76$ \\
\hline $\mathrm{CD}_{11 \mathrm{c}^{+} \mathrm{CD} 4^{+}}$ & N.R. & N.R. & 0,12 & 0,17 & $0,14 \pm 0,03$ \\
\hline $\mathrm{CD} 1 \mathrm{C}^{+} \mathrm{B} 220^{+}$ & 0,51 & 0,21 & 2,48 & 1,14 & $1,08 \pm 1,00$ \\
\hline
\end{tabular}

N.R = Não realizado

Tabela 2. Porcentagem de células $\mathrm{T} \mathrm{CD} 4^{+} \mathrm{CD} 25^{+} \mathrm{Foxp}^{+}$(definidas por citometria de fluxo) obtidas após 5 dias de co-cultura entre células dendríticas e células de linfonodo. Dados referentes a 4 experimentos realizados.

$\mathrm{CD}^{+}{ }^{+} \mathrm{CD} 25^{+} \mathrm{Foxp3}^{+}(\%)$

Experimento $1 \quad$ Experimento $2 \quad$ Experimento $3 \quad$ Experimento $4 \quad$ Media + desvio padrão

\begin{tabular}{cccccc}
\hline LN & 8,50 & 8,67 & 5,19 & 9,29 & $7,91 \pm 1,84$ \\
\hline iDC & 20,90 & 15,16 & 14,80 & 25,58 & $19,11 \pm 5,13$ \\
\hline iDC+APO & 27,35 & 22,34 & 25,47 & 27,62 & $25,69 \pm 2,43$ \\
\hline mDC & 19,07 & 14,38 & 16,80 & 16,65 & $16,72 \pm 1,91$ \\
\hline mDC+APO & 17,90 & 17,50 & 22,26 & 18,23 & $18,97 \pm 2,21$
\end{tabular}

$\mathrm{LN}=$ células de linfonodo. $\mathrm{iDC}=$ células de linfonodo após co-cultura com DCs imaturas. iDC+APO = células de linfonodo após co-cultura com DCs imaturas incubadas com células alogênicas em apoptose. $\mathrm{mDC}=$ células de linfonodo após co-cultura com DCs ativadas por LPS. mDC+APO = células de linfonodo após co-cultura com DCs ativadas por LPS e incubadas com células alogênicas em apoptose. 
Tabela 3. Porcentagem de células $\mathrm{T} \mathrm{CD4}{ }^{+} \mathrm{CD} 25-\mathrm{Foxp}^{+}$(definidas por citometria de fluxo) obtidas após 5 dias de co-cultura entre células dendríticas e células de linfonodo. Dados referentes a 4 experimentos realizados.

\section{CD4+CD25-Foxp3 ${ }^{+}(\%)$}

\begin{tabular}{cccccc}
\hline & Experimento 1 & Experimento 2 & Experimento 3 & Experimento 4 & $\begin{array}{c}\text { Media }+ \text { desvio } \\
\text { padrão }\end{array}$ \\
\hline LN & 5,24 & 3,31 & 2,66 & 4,03 & $3,81 \pm 1,10$ \\
\hline iDC & 2,78 & 2,08 & 1,39 & 1,84 & $2,02 \pm 0,58$ \\
\hline iDC+APO & 2,08 & 1,59 & 0,91 & 0,72 & $1,32 \pm 0,62$ \\
\hline mDC & 5,22 & 3,16 & 1,08 & 1,93 & $2,84 \pm 1,79$ \\
\hline mDC+APO & 3,71 & 1,11 & 0,68 & 1,26 & $1,69 \pm 1,36$
\end{tabular}

$\mathrm{LN}=$ células de linfonodo. iDC = células de linfonodo após co-cultura com DCs imaturas. iDC+APO = células de linfonodo após co-cultura com DCs imaturas incubadas com células alogênicas em apoptose. $\mathrm{mDC}=$ células de linfonodo após co-cultura com DCs ativadas por LPS. mDC+APO = células de linfonodo após co-cultura com DCs ativadas por LPS e incubadas com células alogênicas em apoptose.

Tabela 4. Porcentagem de células T CD4+CD25+Foxp3- (definidas por citometria de fluxo) obtidas após 5 dias de co-cultura entre células dendríticas e células de linfonodo. Dados referentes a 4 experimentos realizados.

\section{$\mathrm{CD}^{+}{ }^{+} \mathrm{CD} 25^{+}{ }^{+} \operatorname{oxp}^{-}(\%)$}

\begin{tabular}{cccccc}
\hline & Experimento 1 & Experimento 2 & Experimento 3 & Experimento 4 & $\begin{array}{c}\text { Media +/- } \\
\text { desvio padrão }\end{array}$ \\
\hline LN & 3,68 & 0,96 & 3,90 & 3,95 & $3,12 \pm 1,44$ \\
\hline iDC & 2,14 & 2,13 & 7,17 & 2,96 & $3,60 \pm 2,41$ \\
\hline iDC+APO & 2,39 & 3,37 & 4,06 & 8,79 & $4,65 \pm 2,84$ \\
\hline mDC & 2,59 & 5,77 & 5,32 & 2,86 & $4,13 \pm 1,64$ \\
\hline mDC+APO & 2,70 & 8,87 & 8,91 & 5,98 & $6,61 \pm 2,94$
\end{tabular}

$\mathrm{LN}=$ células de linfonodo. $\mathrm{iDC}=$ células de linfonodo após co-cultura com DCs imaturas. iDC+APO = células de linfonodo após co-cultura com DCs imaturas incubadas com células alogênicas em apoptose. $\mathrm{mDC}=$ células de linfonodo após co-cultura com DCs ativadas por LPS. mDC+APO = células de linfonodo após co-cultura com DCs ativadas por LPS e incubadas com células alogênicas em apoptose. 
Tabela 5. Porcentagem de células $\mathrm{T} \mathrm{CD4}{ }^{+} \mathrm{Foxp}^{+}$(definidas por citometria de fluxo) obtidas após 5 dias de co-cultura entre células dendríticas e células de linfonodo. Dados referentes a 4 experimentos realizados.

$$
\mathrm{CD}^{+} \mathrm{Foxp}^{+}(\%)
$$

\begin{tabular}{|c|c|c|c|c|c|}
\hline & Experimento 1 & Experimento 2 & Experimento 3 & Experimento 4 & $\begin{array}{c}\text { Media } \pm \text { desvio } \\
\text { padrão }\end{array}$ \\
\hline $\mathrm{LN}$ & 13,74 & 11,98 & 7,85 & 13,32 & $11,72 \pm 2,68$ \\
\hline iDC & 23,68 & 17,24 & 16,19 & 27,42 & $21,13 \pm 5,34$ \\
\hline $\mathrm{iDC}+\mathrm{APO}$ & 29,43 & 23,93 & 26,38 & 28,34 & $27,02+2,41$ \\
\hline $\mathrm{mDC}$ & 24,29 & 17,54 & 17,88 & 18,58 & $19,57 \pm 3,17$ \\
\hline$m D C+A P O$ & 21,61 & 18,61 & 22,94 & 19,49 & $20,66+1,97$ \\
\hline
\end{tabular}

$\mathrm{LN}=$ células de linfonodo. $\mathrm{iDC}=$ células de linfonodo após co-cultura com DCs imaturas. iDC+APO = células de linfonodo após co-cultura com DCs imaturas incubadas com células alogênicas em apoptose. $\mathrm{mDC}=$ células de linfonodo após co-cultura com DCs ativadas por LPS. mDC+APO = células de linfonodo após co-cultura com DCs ativadas por LPS e incubadas com células alogênicas em apoptose. 
Tabela 6. Porcentagem de células $\mathrm{T} \mathrm{CD} 4^{+} \mathrm{CD} 25^{+} \mathrm{Foxp}^{+}$(definidas por citometria de fluxo) obtidas após 5 dias de co-cultura entre células dendríticas e células de linfonodo previamente depletadas de células $\mathrm{T} \mathrm{CD4}{ }^{+} \mathrm{CD} 25^{+}$. Dados referentes a 2 experimentos realizados.

$\mathrm{CD}^{+}{ }^{+} \mathrm{CD} 25^{+} \mathrm{Foxp}^{+}(\%)$

Experimento 1

Experimento 2

Media \pm desvio padrão

\begin{tabular}{cccc}
\hline $\begin{array}{c}\mathrm{LN} \\
\text { (pós-depleção) }\end{array}$ & $2,50^{*}$ & $1,56^{*}$ & $2,03 \pm 0,66$ \\
\hline $\mathrm{iDC}$ & 7,80 & 2,89 & $5,34 \pm 3,47$ \\
\hline $\mathrm{iDC}+\mathrm{APO}$ & 12,63 & 6,67 & $9,65 \pm 4,21$ \\
$\mathrm{mDC}$ & 9,65 & 3,67 & $6,66 \pm 4,23$ \\
\hline $\mathrm{mDC}+$ APO & 9,40 & 4,50 & $6,95 \pm 3,46$
\end{tabular}

$\mathrm{LN}=$ células de linfonodo. iDC= células de linfonodo após co-cultura com DCs imaturas. iDC+APO = células de linfonodo após co-cultura com DCs imaturas incubadas com células alogênicas em apoptose. $\mathrm{mDC}=$ células de linfonodo após co-cultura com DCs ativadas por LPS. mDC+APO = células de linfonodo após co-cultura com DCs ativadas por LPS e incubadas com células alogênicas em apoptose.

* A porcentagem de células $C D 4^{+} \mathrm{CD} 25^{+}$Foxp $3^{+}$foi estimada a partir da porcentagem desta população celular observada na população $\mathrm{CD}^{+}{ }^{+} \mathrm{CD} 25^{+}$total em linfonodos de animais naive. Para este cálculo utilizamos a média da porcentagem de células $C D 4^{+} C D 25^{+} F o x p 3^{+}$observada na população $\mathrm{CD} 4^{+} \mathrm{CD} 25^{+}$tendo como base os resultados de citometria de fluxo realizados e descritos na tabela 2. A porcentagem obtida foi de $71,76 \%$. 
Tabela 7. Porcentagem de células $\mathrm{T} \mathrm{CD4}{ }^{+} \mathrm{CD} 25-\mathrm{Foxp}^{+}{ }^{+}$(definidas por citometria de fluxo) obtidas após 5 dias de co-cultura entre células dendríticas e células de linfonodo previamente depletadas de células $\mathrm{T} \mathrm{CD} 4^{+} \mathrm{CD} 25^{+}$. Dados referentes a 2 experimentos realizados.

\section{$\mathrm{CD}^{+}{ }^{+} \mathrm{CD} 25-\mathrm{Foxp}^{+}(\%)$}

\section{Experimento 1}

Experimento 2

Media + desvio padrão

\begin{tabular}{cccc}
\hline $\begin{array}{c}\mathrm{LN} \\
\text { (pós-depleção) }\end{array}$ & N.R. & N.R. & N.R. \\
\hline iDC & 1,35 & 1,08 & $1,21 \pm 0,19$ \\
\hline iDC+APO & 0,73 & 0,64 & $0,68 \pm 0,06$ \\
\hline mDC & 0,93 & 0,90 & $0,91 \pm 0,02$ \\
\hline mDC+APO & 0,58 & 0,63 & $0,60 \pm 0,03$
\end{tabular}

N.R = Não realizado

$\mathrm{LN}=$ células de linfonodo. iDC = células de linfonodo após co-cultura com DCs imaturas. iDC+APO = células de linfonodo após co-cultura com DCs imaturas incubadas com células alogênicas em apoptose. $\mathrm{mDC}=$ células de linfonodo após co-cultura com DCs ativadas por LPS. $\mathrm{mDC}+\mathrm{APO}=$ células de linfonodo após co-cultura com DCs ativadas por LPS e incubadas com células alogênicas em apoptose. 
Tabela 8. Porcentagem de células T CD4+CD25+Foxp3- (definidas por citometria de fluxo) obtidas após 5 dias de co-cultura entre células dendríticas e células de linfonodo previamente depletadas de células $\mathrm{T} \mathrm{CD} 4^{+} \mathrm{CD} 25^{+}$. Dados referentes a 2 experimentos realizados.

\section{$\mathrm{CD}^{+}{ }^{+} \mathrm{CD} 25^{+} \mathrm{Foxp} 3^{-}(\%)$}

\section{Experimento 1}

Experimento 2

Media \pm desvio padrão

\begin{tabular}{cccc}
\hline $\begin{array}{c}\mathrm{LN} \\
\text { (pós-depleção) }\end{array}$ & $0,98^{*}$ & $0,61^{*}$ & $0,79 \pm 0,26$ \\
\hline iDC & 3,88 & 1,64 & $2,76 \pm 1,58$ \\
\hline iDC+APO & 8,11 & 6,59 & $7,35 \pm 1,07$ \\
\hline $\mathrm{mDC}$ & 7,77 & 3,69 & $5,73 \pm 2,88$ \\
\hline $\mathrm{mDC}+\mathrm{APO}$ & 14,68 & 8,13 & $11,40 \pm 4,63$
\end{tabular}

$\mathrm{LN}=$ células de linfonodo. $\mathrm{iDC}=$ células de linfonodo após co-cultura com DCs imaturas. iDC+APO = células de linfonodo após co-cultura com DCs imaturas incubadas com células alogênicas em apoptose. $\mathrm{mDC}=$ células de linfonodo após co-cultura com DCs ativadas por LPS. mDC+APO = células de linfonodo após co-cultura com DCs ativadas por LPS e incubadas com células alogênicas em apoptose.

* A porcentagem de células CD4+CD25+Foxp3- foi estimada a partir da porcentagem desta população celular observada na população $\mathrm{CD}^{+}{ }^{+} \mathrm{CD} 25^{+}$total em linfonodos de animais naive. Para este cálculo utilizamos a média da porcentagem de células $C D 4^{+} \mathrm{CD} 25^{+}$Foxp3- observada na população $C D 44^{+} \mathrm{CD} 25^{+}$ tendo como base os resultados de citometria de fluxo realizados e descritos na tabela 4 . A porcentagem obtida foi de $28,24 \%$. 
Tabela 9. Porcentagem de células $\mathrm{T} \mathrm{CD4}{ }^{+} \mathrm{Foxp}^{+}$(definidas por citometria de fluxo) obtidas após 5 dias de co-cultura entre células dendríticas e células de linfonodo previamente depletadas de células $T$ $\mathrm{CD} 4^{+} \mathrm{CD} 25^{+}$. Dados referentes a 2 experimentos realizados.

\section{$\mathrm{CD}^{+}{ }^{+} \mathrm{Foxp}^{+}(\%)$}

Experimento 1

Experimento 2

Media \pm desvio padrão

\begin{tabular}{cccc}
\hline $\begin{array}{c}\mathrm{LN} \\
\text { (pós-depleção) }\end{array}$ & N.R. & N.R. & N.R. \\
\hline iDC & 9,15 & 3,97 & $6,56 \pm 3,66$ \\
\hline iDC+APO & 13,36 & 7,31 & $10,33 \pm 4,27$ \\
\hline mDC & 10,58 & 4,57 & $7,57 \pm 4,24$ \\
\hline mDC+APO & 9,98 & 5,13 & $7,55 \pm 3,42$
\end{tabular}

N.R = Não realizado

$\mathrm{LN}=$ células de linfonodo. $\mathrm{iDC}=$ células de linfonodo após co-cultura com DCs imaturas. iDC+APO = células de linfonodo após co-cultura com DCs imaturas incubadas com células alogênicas em apoptose. $\mathrm{mDC}=$ células de linfonodo após co-cultura com DCs ativadas por LPS. $\mathrm{mDC}+\mathrm{APO}=$ células de linfonodo após co-cultura com DCs ativadas por LPS e incubadas com células alogênicas em apoptose. 